\title{
Do Foreign Firms Crowd Out Domestic Firms? The Evidence from the Czech Republic
}

\author{
Renáta Kosová ${ }^{1}$ \\ Ph.D. Candidate, Corporate Strategy and International Business \\ University of Michigan Business School \\ 701 Tappan Street, Room 2259 \\ Ann Arbor, MI 48109-1234 \\ E-mail: kosova@umich.edu \\ Tel: 734-327-0385
}

Work in progress, comments are welcome.

${ }^{1}$ I want to thank for an extraordinary help to my comittee chairs: Prof. Francine Lafontaine and Prof. Jan Svejnar and for valuable comments, suggestions and support to Professors: Kai-Uwe Kühn, Joanne Oxley, and Katherine Terrell. I also thank very much for comments to Peter Katušćák, David Greenstreet and Rasto Novák for excellent research assistance. In addition, I would, like to thank Cristina Negrut, William Davidson Institute and Kresge Library for data access. 


\begin{abstract}
I analyze the effect of foreign firm presence on the growth and survival of domestic firms. I separate the two opposing effects that foreign firms may have on domestic firms: a negative "market stealing or crowding out" effect and a positive "technology spillover" effect. Unlike previous studies, which analyzed spillovers by estimating firm production functions, I use a model that combines a dominant firm/competitive fringe framework with a model of firm and industry dynamics (Jovanovic,1982 and Sun, 2002). In my model, foreign firms as a group are represented by the dominant firm and domestic firms form a competitive fringe. As in Jovanovic (1982), domestic firms face uncertainty about their production efficiency and learn about it while operating in the industry. Following Sun (2002), I also assume that domestic firms' production is affected by cumulative technology shocks (technology spillovers). I use the model to derive empirical predictions for the growth and survival of domestic firms. I test these using a unique firm-level panel dataset from the Czech Republic during 1994-2001. My results show evidence of both technology spillover and crowding out effects. However, crowding out appears to be a short-term or static phenomenon: initial foreign entry increases the exit rate of domestic firms. Subsequently, however, the growth of the foreign industry segment is accompanied by increases in both the growth rate and survival of domestic firms. I also find that firms in industries without foreign presence have higher exit rates than firms in industries with foreign presence. While findings on crowding out effects are robust across different subsamples, sub-sample analyses also suggest that the primary beneficiaries of technology spillovers are firms in technologically advanced industries.
\end{abstract}




\section{Introduction}

I analyze the effect of foreign presence on the growth and survival/exit of domestic firms in a transitional economy, namely the Czech Republic. Firm entry, growth and exit are the underpinnings of job creation and destruction in the economy. Knowing how foreign presence affects domestic firm growth rates and survival is an important task in assessing the impact of FDI on the domestic economies (see Bilsen and Konings (1997)). Some authors, along with most anti-globalisation protesters worry that foreign firms will monopolize domestic markets and destroy domestic firms. ${ }^{1}$ This fear that domestic firms can be displaced or crowded out by foreign firms has complicated the restructuralization process in many transitional countries. ${ }^{2}$ The goal of my work is to foster a deeper understanding of these issues.

Transitional countries moreover often try to attract FDI by offering generous investment packages (e.g. tax holidays, import duty exemptions). One reason for these preferential policies is the belief that multinational firms (MNCs) confer "technology spillovers" to domestic firms. This view, supported by early case studies and industry-level findings (e.g. Caves, 1974; Blomström, 1986), emphasizes that multinational activity should generate technology/knowledge externalities, i.e. facilitate the transfer of more efficient technology and management practices from foreign to domestic firms. ${ }^{3}$ However, recent firm-level panel studies such as Haddad and Harrison (1993), Chung et al. (1998), Aitken and Harrison (1999), have found negative or no spillover effects of FDI. Studies on FDI spillovers in transitional economies have reached similar conclusions: negative FDI spillovers were found in the Czech Republic (e.g. Djankov and Hoekman, 2000; Kinoshita, 2001), and in Bulgaria, Romania and Poland (e.g. Konings (1999)).

Aitken and Harrison (1999) explain these contradictory findings using the concept of "market stealing", or crowding out. They argue that even though technology spillovers may exist, more efficient foreign firms may draw demand from the less efficient domestic firms, thus forcing them to cut production. This negative competitive effect, which is fundamentally the effect emphasized by domestic protectionists, may outweigh the positive technology spillovers, giving rise to a negative net effect from foreign presence or entry on domestic firm performance. Aitken and Harrison further suggest that the negative effect of FDI may be only temporary, because in the long run the least efficient domestic firms exit and the productive advantage of foreign firms might be transferred to domestic firms through labor mobility. Blomström et al. (2000) further argue that positive FDI spillovers are less likely in countries/industries where the gap between the technologies of domestic and foreign firms is large, thereby allowing foreign affiliates to "crowd out" less efficient local firms from the domestic market. ${ }^{4} 5$ These new results and arguments clearly make the above-mentioned policies focused on attracting FDI more questionable, especially

\footnotetext{
${ }^{1}$ Ernst (1997) describes how globalization increased concentration in hard disk drives electronics industry.

${ }^{2}$ Cordonnier (2002) discusses this topic in relation to restructuralization of banking industry in Russia.

${ }^{3}$ The important role of MNCs in the technology diffusion was already emphasized by Findlay (1978).

${ }^{4}$ See Blomström, Kokko, Zejan (2000), pg.188.

${ }^{5}$ Dawar and Frost (1999) also discuss that in emerging markets FDI inflows very often represents a "death sentence" for local firms, because they were for long time protected by national governments and now they are unable to compete with MNCs that posses various technological and financial advantages.
} 
in developing or transitional countries.

To provide more evidence on these issues, in this paper I consider two main questions: 1) How significant is the crowding-out effect compared to the technology spillover effect in a transitional country? 2) Is crowding out a dynamic effect, where domestic firms continue to cut production over time as foreign firms grow in the domestic industry, or is it a short-term static phenomenon realized upon foreign entry into the industry? To address these questions, I use a theoretical framework and empirical methodology that overcome the following two shortcomings from the literature. First, I explicitly separate and estimate the two effects. Previous studies usually included a single measure for FDI presence and as such, they could only offer policy makers a sense of the net impact of FDI, i.e. whether the positive technology spillovers outweigh the negative competitive effects or vice versa. However, if the net effect is zero, as it was the case in several studies, we do not know whether the two effects are small and unimportant or both large, but cancelling each other out. From a theoretical and a policy perspective, it is important to separate and individually estimate these two effects so we can later assess what factors determine their relative sizes and how each can be affected by market and institutional features. ${ }^{6}$ Second, I incorporate domestic firm exit decisions into the analysis. Most research on FDI spillovers has neglected the possibility that domestic firms may not only reduce their output level, but also exit as a result of foreign competition. In that context, the positive evidence on FDI spillovers, based only on data of surviving firms, might be biased upward and mislead policy makers. Interestingly, the impact of foreign presence on domestic firm survival or exit has not received much attention in the international business literature to date. Görg and Strobl (2000) and De Backer and Sleuwaegen (2003) are the only two studies that have analyzed the impact of FDI on firm survival or exit. These studies however focus on developed countries, namely Ireland and Belgium, as opposed to transitional economies.

In my analyses, I rely on a model that combines a dominant firm/competitive fringe framework with a Jovanovic-type model of firm and industry dynamics (Jovanovic,1982; Sun 2002), from industrial organization literature. This model provides empirical predictions for the growth and exit of domestic firms, which I test these using a unique 1994-2001 panel dataset on foreign and domestic firms in the Czech Republic.

I find evidence of both technology spillovers and crowding out. However, crowding out is a short-term or static phenomenon in my data: foreign entry increases the exit rates of domestic firms at the time, but subsequently the growth of the foreign industry segment is accompanied by increases in both the growth rate and survival of domestic firms.

The paper is organized as follows. The next section discusses the advantages of the Czech Republic as an empirical setting for my study. I present the theoretical model in section 3

\footnotetext{
${ }^{6}$ Some studies have included measures of industry concentration, such as a Herfindahl index, in the production functions to control for competitive effects, e.g. Haskel et al.(2002) or Smarzynka Javorcik(2003). But these studies do not directly analyze the competition between domestic and foreign firms. Blomström et al (1996) on the other hand estimate a simultaneous equations model at the industry level where the domestic value added per employee is a function of foreign employment share, which captures the technology spillovers, and of foreign value added, which captures the competitive effects. They find that both have a positive impact on domestic value added.
} 
and discuss the technology spillovers in section 4. Section 5 describes the data and section 6 addresses variable measurement issues. Sections 7 and 8 present the empirical methodology for the estimation of domestic firm growth, survival and exit probability. The remaining sections summarize my empirical findings and conclusions.

\section{Why the Czech Republic?}

There are several reasons why I have selected the Czech Republic (CR) as the empirical setting for my study. First, I want to focus on a single country in my analyses, because the country-specific legal and institutional features might affect FDI presence and I want to avoid the difficulties associated with controlling for complex cross-country differences.

Second, as Table 1.1. shows, the CR is among the countries with the highest cumulative and per capita FDI inflows in Central and Eastern Europe. Hence there should be significant foreign presence, a necessary pre-condition to address the questions raised here.

Third, compared to other transitional countries, such as Hungary or Poland, which also attracted significant FDI inflows, the CR was virtually closed to FDI until the very beginning of the transition in 1989. In addition, until the early 1990's the prices and production were set via central planning, because price liberalization started in 1991. As I discuss in the theoretical section, due to this almost complete protection from foreign competition and the lack of market mechanism, the CR fits quite well the theoretical assumptions I make in my analysis.

Fourth, the CR is one of the most economically advanced transitional countries in Central Europe, and as such, it has served as a model for other countries that started their transitions later on, such as Bulgaria, Romania and the countries of the former Soviet Union. ${ }^{7}$

Fifth, my data cover the period 1994-2001 which is associated with macroeconomic stabilization, privatization of state-owned enterprises and other reforms. Unlike other Central European countries the CR also experienced a recession from 1997-1999. All these changes help to bring variation in important variables in my empirical setting.

Last, the CR's upcoming membership in the European Union (EU) means that in very near future it will not be possible for the Czech firms to lobby for the protection from EU originated FDI and imports. Hence, from both policy and firm strategy perspectives it is not only interesting, but also important, to study the effects of foreign presence on domestic industries in this country. ${ }^{8}$

\footnotetext{
${ }^{7}$ Lízal and Svejnar (2002)

${ }^{8}$ Deloitte \& Touche (D\&T) surveyed more than 100 firms in the Czech Republic, Hungary, Poland, Slovakia and Slovenia and concluded that since the domestic firms lag behind foreign affiliates e.g. in production efficiency, organizational issues and human resource practices, domestic firms are unprepared for further globalization and competition within the EU (SITA, Reuters May 22, 2002).
} 


\section{Theoretical model}

\subsection{Intuition for modelling the crowding out effect}

Aitken and Harrison (1999) argue that even though technology spillovers may exist, foreign firms can draw demand from less efficient domestic producers, thereby forcing them to cut production. They refer to this competitive effect as market-stealing. If such market stealing appears between time $t$ and $t+1$, the foreign presence should be negatively correlated with domestic firm growth rates because part of the domestic production is crowded out by the foreign competition.

There are several issues of interest in relation to these competitive effects. First, market stealing can be a one time phenomenon, realized at the time of foreign entry into the domestic industry, or it can arise continuously over time as foreign firms increase their production in the domestic markets. I refer to the latter as dynamic crowding out, while the former represents a static crowding out effect. Analyzing how crowding out works will help us understand whether the adjustment to FDI inflows is a shock therapy or a gradual adjustment process.

Second, whether foreign competition only reduces the output of the domestic firms, as suggested by Aitken and Harrison (1999), or even induces their exit depends on the size of demand lost due to foreign competition and thus on the efficiency gap between foreign and domestic firms. I interpret both reduction in output as well as domestic firm exit as evidence of crowding out.

If crowding out is a dynamic phenomenon, then holding domestic market demand constant, foreign sales expansion/growth should reduce the sales of domestic firms over time and lead thus to smaller domestic growth rates. So foreign growth would have a negative impact on the growth rates and survival time of domestic firms - or a positive effect on the probability of exit. On the other hand, if crowding out is a static phenomenon, it will be the time of foreign entry rather than the foreign growth that should be negatively correlated with the growth rates and survival of domestic firms. Beyond the foreign entry period the demand patterns for both domestic and foreign firms should be driven only by common exogenous shifts in aggregate demand.

To test these hypotheses, I use a theoretical model that combines a standard model of dominant firm and competitive fringe and a stochastic model of firm dynamics with cumulative technology shock by Sun (2002), which relies on Jovanovic's (1982) seminal work on industry dynamics. In Jovanovic's framework the heterogeneous firms operate in a competitive industry with incomplete information. Firm heterogeneity arises from differences in the firm true cost efficiency, which is unknown by the firms themselves, and about which firms learn over time via operating in the industry. As a result of this learning efficient firms grow and survive, while inefficient firms decline and fail. In the end, firms differ in size because some of them discover that they are more efficient than others. Jovanovic's (1982) model explains the stylized empirical facts that smaller and younger firms grow faster and are less likely to survive than old and large firms.

Previous studies on FDI spillovers have focused primarily on the effect of foreign presence on the productivity of domestic firms. They do so by estimating production functions for domestic firms, and treating foreign presence as one of the inputs that enter the production function. There are several advantages to my approach as compared to the standard productivity function 
framework: First, Jovanovic's (1982) model is based on firm's learning process in the market which generates firm entry and exit patterns that are also affected by FDI presence. These patterns are missing in a production function approach that focuses on firm productive efficiency, but does not model firm or industry dynamics. ${ }^{9}$ The Jovanovic model implies that firm growth depends on firm size, age and changes in market demand. Hence the estimation of firm growth does not require input measurement, because all the inputs are summarized within a single variable - firm size, usually measured by firm output or sales. So one avoids the input endogeneity problems in productivity estimations (see Olley \& Pakes, 1996), also present in the productivity based analysis of FDI spillovers, but which most studies do not take into account. ${ }^{10}$ In addition, my specification controls for firm age which is missing in the productivity functions yet has been shown in many other studies to be an important determinant of firm growth.

Second, as I discuss next, the assumptions underlying dominant firm/competitive fringe industry structure approximate the key characteristics of the imperfectly competitive environments in which MNCs are expected to operate as per the international business literature.

Third, the cumulative technology shocks introduced by Sun (2002) into Jovanovic's model allow me to incorporate technology spillovers and separate them from the crowding out effect.

\subsection{Dominant firm-competitive fringe structure and MNCs theory}

A domestic market with foreign presence resembles a dominant firm-competitive fringe industry structure in several ways. ${ }^{11}$ For technical simplicity I assume that foreign firms as a group are a single "dominant firm" while domestic firms form the "competitive fringe" in the industry. ${ }^{12}$ The main assumption of a classical dominant firm/competitive fringe model is that a dominant firm has a higher market share than the individual firms in the fringe and thus it has impact on market price while the firms in competitive fringe take price as given. However, collectively competitive fringe firms (henceforth "fringe firms") may have a substantial market share. The dominant firm behaves as a monopoly with respect to its residual demand (market demand minus total supply of competitive fringe), so the existence of the competitive fringe limits the market power of the dominant firm. ${ }^{13}$ Whether a dominant firm can exercise market power depends on the number of firms that can enter and exit the competitive fringe, how fast they can enter or exit, and the differences in production costs between the dominant and fringe firms. In this model a single firm becomes dominant in the market when it benefits from at least some of the following competitive advantages: ${ }^{14}$

\footnotetext{
${ }^{9}$ Blomström and Sjöholm (1998) also point out that competitive pressures from FDI should be analyzed from the perspective of industry dynamics, not total factor productivity.

${ }^{10}$ Exceptions are: Smarzynska Javorcik (2003), and Blalock (2002), who control for endogeneity of inputs using Olley \& Pakes (1996) method and Smarzynska Javorcik \& Spatareanu (2003), who use alternative approach by Levinsohn \& Petrin (2000).

${ }^{11}$ See Stigler (1965) for an introduction of the dominant firm / competitive fringe model.

${ }^{12}$ I model the relationship between domestic and foreign firms, not the relationship among foreign firms in the industry. In the empirical section MNCs as a group (the foreign part of the industry) represents the DF.

${ }^{13}$ Das (1987) also uses the DF/CF industry structure to model technology transfer between the foreign subsidiary and domestic firms. However, there is no exit or entry in her model.

${ }^{14}$ See Carlton and Perloff (2000), ch.4, pg. 110-112.
} 
1. Lower costs than firms in the competitive fringe due to:

- better management or technology, which may be protected by patents;

- early entry into other markets and thus learning by doing;

- economies of scale;

- favorable public policy (e.g. lower tax rates, subsidies, other government privileges)

2. A superior product in a differentiated product market. This superiority may be due to a firm reputation for quality, or technical superiority protected by patents.

These assumptions about dominant firm coincide with the asset ownership advantages of MNCs emphasized by the international business literature (see Ownership-Localization- Internalization theory by Dunning (1988)). ${ }^{15}$ Already Hymer (1960) emphasized that scale economies, knowledge or credit advantages, distribution networks or product differentiation that MNCs possess will help to increase their market dominancy. Moreover, the MNCs can utilize vertical integration across countries to reduce costs, a strategy that is unavailable to a firm confined to one country. Empirical studies have also shown that MNCs are usually characterized by high levels of $\mathrm{R} \& \mathrm{D}$ expenditures relative to sales, a large share of professional and technical workers, large values of intangible assets relative to their market value, new or technically complex products, high levels of product differentiation, and advertising. ${ }^{16}$ Some studies have also found that corporate age is highly correlated with multinationality. ${ }^{17}$

Given the institutional settings in most transitional countries, such as the CR, one can expect that the above assumptions about domestic and foreign firms will be satisfied. In my 1994-2001 sample, many firms operated for a long time under the socialist regime when prices and output were set via central planning. The firms were owned by the state and heavily subsidized. There was no market competition and thus no firm incentives to make production more efficient via R\&D or to develop management practices such as advertising, marketing or competitive compensation typical of western firms. Moreover, the embargo on exports of advanced technology to communist countries, imposed by western countries in the 1980s, further enlarged the technology gap between communist and capitalist countries. ${ }^{18}$ Though $75 \%$ of the firms had been privatized by the end of 1995, most of them are still today in the restructuralization process and learning how to operate in a market economy. ${ }^{19}$ On the other hand, the de-novo Czech firms founded after 1989 - the

\footnotetext{
${ }^{15}$ OLI theory predicts that three conditions must be present for a firm to make FDI: O-ownership advantage: the firm must possess product, production processes or intangible asset that other firms do not have access to due to protection by a patent, blueprint, trade secret protection or trademark, which confer market power or a cost advantage sufficient to outweigh the uncertainty from doing business abroad. L-location advantage: production in the foreign market must be more profitable (due to large demand, cheaper inputs, direct access to natural resources or customers) than production at home and export to the foreign market. I-Internalization advantage: it must be more profitable to exploit the firm's ownership advantage internally than to license it in the foreign market.

${ }^{16}$ See Markusen (1995) for summary of these findings.

${ }^{17}$ See e.g. Blomström and Lipsey (1991), Morck and Yeung (1991) or Beaudreau (1986).

${ }^{18}$ See Lízal and Svejnar (2002)

${ }^{19}$ See Gupta, Ham, Svejnar (2001).
} 


\section{$\begin{array}{ll}\text { a) Competitive Fringe }(\mathrm{CF}) & \text { b) Dominant Firm (DF) }\end{array}$}

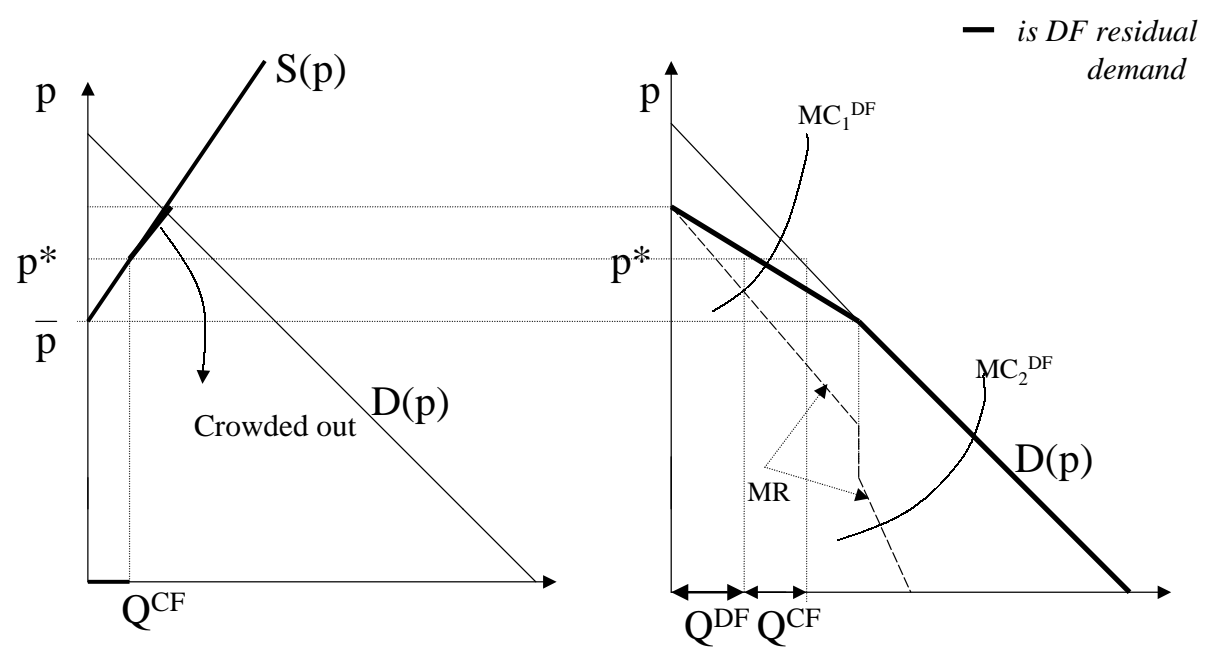

FIGURE 1: Dominant firm and competitive fringe

start of transition- are too young (in my sample) to already possess market power. Hence, one can expect that foreign firms with long-term experience in competitive markets and advanced technologies or products can enter market such as the CR with significant advantages and easily gain market leadership. ${ }^{20}$

Table 1.2 compares several performance characteristics of domestic and foreign firms for the 142 competitive industries used in my analysis. ${ }^{21}$ These comparisons confirm that the main assumptions of the DF/CF model are satisfied in my data: foreign firms on average have significantly larger market shares, greater value added and growth rates, higher $\mathrm{K} / \mathrm{L}$ ratios, more intangible assets and better financial performance, namely higher return on assets and cashflow. In addition, profit margins suggest that while domestic firms on average operate on zero profit margin, foreign firms have positive profits. The assumption of favorable policies with respect to dominant firm also holds: In 1998 the Czech government introduced different investment incentives to attract more FDI. ${ }^{22}$

\subsection{Static crowding out}

Figure 1 presents the standard dominant firm / competitive fringe model. This graph demonstrates the static crowding out effect related to foreign entry into a domestic industry. Figure $1 a$ shows the total market demand for a homogeneous product $D(p)$, and total competitive fringe

\footnotetext{
${ }^{20}$ E.g. for chemical industry in the CR the ICEG EC Report (2003) says:"...concentration is being controlled by a closed number of great MNCs... The need of capital can arise some problems for small and medium sized enterprises due to their less economic power, insufficient legal, economic, technical and management capacities".

${ }^{21}$ I define competitive industry as one with at least 10 domestic firms (see the data section).

${ }^{22}$ Investment incentives include up to 10 years tax holidays, duty-free imports and financial support by government for training and job creation (EBRD Report 2002).
} 
supply $S(p)$. Price $\bar{p}$ is the shut-down price of the fringe (domestic) firms. Figure $1 b$ shows the situation from the perspective of the dominant firm, where the residual demand curve of the dominant firm is given by the horizontal difference between market demand $D(p)$ and total competitive fringe supply $S(p)$. The dominant firm maximizes profits by choosing the output $Q^{D F}$, where $M R=M C^{D F}$. This in turn determines the market price and hence the total quantity the competitive fringe will sell on the market, $Q^{C F}$. After foreign entry, the domestic firms in the CF must, as a whole, produce less. This appears through reduction in every firm's output level, or firm exit, or both. The amount of crowding out depends on the difference between the marginal costs of the foreign and domestic firms. If the marginal costs of dominant firm are very low compared to $M C$ of domestic firms (say $M C_{2}^{D F}$ in Figure 1b) then all the fringe (domestic) firms would be crowded out and would exit the market because $M C_{2}^{D F}$ intersects the $M R$ of the dominant firm at the point such that the new price is below $\bar{p}$. However, if the costs of the dominant firm are higher, say $M C_{1}^{D F}$, then the equilibrium price is $p^{*}$ and the domestic firms with shutdown price below $p^{*}$ survive, but produce less.

\subsection{Dynamic crowding out effect}

To analyze the impact of foreign presence on domestic firm growth and exit over time I incorporate the DF/CF model into Jovanovic's framework (1982) with cumulative technology shocks by Sun (2002). The model is solved backwards. First, given the price sequence the fringe firms choose output every period and decide whether to exit. Second, given the total supply of the competitive fringe as a function of prices, the dominant firm chooses an equilibrium price sequence and makes it public at the beginning of the game. Since the driving force of firm dynamics is domestic firms' learning process about their efficiency in the competitive environment I assume that the game starts at the beginning of transition. Only after that do the domestic firms begin to learn about their efficiency and so exit and entry appear. This is consistent with the situation in the Czech Republic, where before the transition started there was neither market competition nor foreign presence, so domestic firms could not learn about their true efficiency.

\subsubsection{Domestic firms - competitive fringe (CF)}

I assume that there are many domestic firms in the competitive fringe, each of them too small to affect price. Every period a firm chooses output $q_{t}$ to maximize its expected profit $\pi_{t}^{e}$ :

$$
\pi_{t}^{e}=\max _{q_{t}}\left[p_{t} q_{t}-C\left(q_{t}\right) T_{t} x_{t}^{e}\right]
$$

where the price sequence, $p \equiv\left\{p_{t}\right\}_{0}^{\infty}$, is known by all firms already at time $0 . C\left(q_{t}\right) T_{t} x_{t}^{*}$ represents firm total costs and $C\left(q_{t}\right)$ is a function that satisfies: $C(0)=0, C \prime(0)=0, C \prime(q)>0, C^{\prime \prime}(q)>0$, $\lim _{q \rightarrow \infty} C \prime(q) \rightarrow \infty$ and $\frac{C^{\prime}}{q C^{\prime \prime}}=k>0 .{ }^{23} \quad x_{t}$ is a random variable independent across firms that

\footnotetext{
${ }^{23}$ All functions: $C=a q^{m}+b$ where $a, b>0$ and $m>1$ satisfy this assumption. Then $k=\frac{1}{m-1}$ is also firm supply elasticity.
} 
represents the inverse of firm production efficiency, where $x_{t}=f\left(\delta_{t}\right)$ and $\delta_{t}=\theta+\varepsilon_{t}$. Then $x_{t}^{e}$ is expectation of $x_{t}$ conditional on information received prior to $t$. The function $f$ is positive, strictly increasing and continuous with $\lim _{\delta_{t} \rightarrow-\infty} A_{1}>0$ and $\lim _{\delta_{t} \rightarrow \infty} A_{2} \leq \infty .{ }^{24}$ Parameter $\theta$ represents the firm's true cost efficiency (or firm type) which is normally distributed among all potential firms with mean $\bar{\theta}$ and variance $\sigma_{\theta}^{2}$.

A firm does not know its $\theta$, but learns about it while operating in the industry by Bayesian updating according to signals that arrive every period. ${ }^{25}$ The signals are generated by random productivity shocks, $\varepsilon_{t} \sim N\left(0, \sigma_{\varepsilon}^{2}\right)$, independent across firms and time. A firm learns about them at the end of a period through realized profits, respectively inferred realizations of $\delta_{t}$ and adjusts its expectation for the next period, $x_{t+1}^{e}$. ${ }^{26}$

Following Sun (2002), I also assume that a firm experiences each period an additional i.i.d technology shock, $u_{t} \sim N\left(\bar{u}, \sigma_{u}^{2}\right)$, where $\bar{u}$ represents the trend in technological progress. $u_{t}>0$ represents a plausible (marginal costs decreasing) technological shock, which is bounded from above by 1 to prevent negative costs. $u_{t}$ cumulates over time, so the firm technology level, $T_{t}=\prod_{j=t-n}^{t}\left(1-u_{j}\right)$, is the cumulated value of all technological shocks a firm has experienced in the past up to and including period $t$, where $n$ is firm age. I assume that at entry a firm does not have any technology improvements yet, so $T_{0}=1$.

According to Sun (2002) this technology shock can represent any shock to firm's production process that have persistent effects on firm efficiency, including a firm's innovation or changes in management (excellent or terrible CEO). However, it can also be interpreted as the impact of a macro-level shock, where the i.i.d property is preserved if $u_{t}$ is seen as a firm-specific adjustment to the common macro shock. I take $u_{t}$ as a representation of technology spillovers, because the FDI inflows constitute a sort of macroeconomic shock for domestic firms, and the technology spillovers are domestic firm specific adjustments to FDI inflows. In this way Sun's framework provides a convenient way to incorporate the effect of the FDI technology spillovers into the profit maximization problem of domestic firms.

A firm chooses $q_{t}$ at the beginning of period $t$ before it observes $x_{t}$, but after it observes $u_{t}$. Then the optimal output choice, $q_{t}^{*}=q\left(p_{t}, T_{t}, x_{t}^{e}\right)$, that maximizes $\pi_{t}^{e}($ see $(1))$, satisfies the FOC:

\footnotetext{
${ }^{24} f$ is introuced in order to allow for firm true efficiency to have flexible impact on the costs in terms of the functional form.

${ }^{25}$ All entrants have the same prior beliefs about their efficiency, $x_{0}=E_{0}\left(f\left(\theta+\varepsilon_{t}\right)\right)$. Each entrant considers itself to be a random draw from $N\left(\bar{\theta}, \sigma_{\theta}^{2}\right)$. This prior distribution is then updated as firm infers $\delta_{t}$. Then in any following period $t$ firm expectations are formed as: $x_{t}^{e}=E\left(x \mid \overline{\delta_{n}}, n\right)=\int f(\delta) d P\left(\delta \mid \overline{\delta_{n}}, n\right)$, where $P\left(\delta \mid \overline{\delta_{n}}, n\right)$ is the normal posterior distribution of $\delta$ conditional on the information a firm has at time $t$, where $n$ is firm age and $\overline{\delta_{n}}=\sum_{i=1}^{n} \delta_{i} / n$. (Jovanovic (1982), pg.652).

${ }^{26}$ At the end of period $t$ a firm's realized profit is: $\pi_{t}=p_{t} q_{t}-C\left(q_{t}\right) T_{t} x_{t}$. Since a firm observes $T_{t}$ already at the beginning of period $t$ (see text below), it can derive $x_{t}$ and then infer $\delta_{t}$, because it also knows $f$. (However, it can not separate $\theta$ from $\varepsilon_{t}$ ). Knowing $\delta_{t}$ a firm's expectations for the next period, $x_{t+1}^{e}$, follow formula in the previous footnote. One implication is that (for given $u_{t+1}$ ) high profits today lead to high growth tomorrow (Jovanovic (1982), pg. 654). The comparison of realized with expected profits: $\pi_{t}-\pi_{t}^{e}=-C\left(q_{t}\right) T_{t}\left(x_{t}-x_{t}^{e}\right)$, implies that if $\pi_{t}>\pi_{t}^{e}$ then a firm revises its expectation downward so: $x_{t+1}^{e}<x_{t}^{e}$ and more profitable firms have higher output and growth rate the next period.
} 
$p_{t}=C^{\prime}\left(q_{t}^{*}\right) T_{t} x_{t}^{e}$ and firm discrete output growth rate is: (see Appendix A1):

$$
\frac{q_{t+1}^{*}-q_{t}^{*}}{q_{t}^{*}}=k\left(\frac{p_{t+1}-p_{t}}{p_{t}}-\frac{x_{t+1}^{e}-x_{t}^{e}}{x_{t}^{e}}+u_{t+1}\right)
$$

Hence the main result from the Jovanovic-Sun framework is that the firm's growth rate increases with larger prices (I derive below how the price changes are affected by the presence of the dominant firm) and the positive technology shock, but decreases with firm's expected inefficiency $\left(x_{t+1}^{e}>x_{t}^{e}\right)$. The firm's updating process implies that firm age and size affect growth through $\frac{x_{t+1}^{e}-x_{t}^{e}}{x_{t}^{e}} \cdot 27$

AGE: All else equal, age has a negative impact on firm growth because older firms (larger $n$ ) have smaller revisions in their expectations (i.e. lower variance of posterior distribution). ${ }^{28}$ For mature firms $x_{t}^{e}$ converges to a constant, meaning that the firm has already learnt its true efficiency. Then the differences in firm growth rates are driven only by firm specific technology shocks (see Sun (2002)).

SIZE: Firm size should have also a negative effect on firm growth. It enters the equation only indirectly via $\theta$. For each $\theta$ there is an optimal size $\widetilde{q}(\theta)$ that a firm should achieve in the long run. All else equal, if we take two firms of the same type $\theta$, but different sizes, such that both firms are smaller than $\widetilde{q}(\theta)$, then the larger firm should be already closer to its optimal size. Hence it must grow more slowly than the smaller firm. On the other hand, if both firms are currently larger than $\widetilde{q}(\theta)$, then the larger firm must decline faster than the smaller firm. Aggregating over all possible $\theta$ 's in a given age cohort, smaller firms should grow faster than larger firms.

\subsubsection{Domestic firm exit and the growth equation}

Besides choosing an output every period, a fringe firm also decides whether to stay or exit the industry (see Appendix A2). There exists a critical value of firm efficiency, $\overline{x_{t}}$, and a critical output, $\overline{q_{t}}\left(p_{t}, T_{t}, \overline{x_{t}}\right)$ at which a firm exits. If a firm decides to exit at the beginning of period $t+1$, then $q_{t+1}^{*}$ must be smaller than $\bar{q}_{t+1}$. This exit size can be expressed in terms of an exit growth rate, $\widetilde{g}_{t+1}=\left(\frac{\bar{q}_{t+1-} q_{t}^{*}}{q_{t}^{*}}\right) .{ }^{29}$ If the firm's optimal growth rate would be less than $\widetilde{g}_{t+1}$, the firm exits, so $q_{t+1}^{*}=0$ and its observed growth rate is -1 . Thus the same variables that affect firm growth should also affect firm exit/survival. Specifically, firm exit rates should decrease with higher prices (since a fringe firm has cost function convex in output at a higher price a firm can produce more and grow), positive technology shock $u_{t+1}$, and higher expectations of firm efficiency, which imply that larger and older firms should have lower exit rates. ${ }^{30}$

\footnotetext{
${ }^{27}$ The normal posterior distribution of $\delta_{t}$ for firm of age $n$ is has mean $E_{\delta n}=\frac{1}{\frac{1}{\sigma_{\theta}^{2}}+\frac{n}{\sigma_{\varepsilon}^{2}}}\left(\frac{\bar{\theta}}{\sigma_{\theta}^{2}}+\frac{\sum^{n} \delta_{j}}{\sigma_{\varepsilon}^{2}}\right)$ and variance $V_{\delta n}=\frac{1}{\frac{1}{\sigma_{\theta}^{2}}+\frac{n}{\sigma_{\varepsilon}^{2}}}+\sigma_{\varepsilon}^{2}($ see Sun $(2002))$

${ }^{28}$ See the formula for $V_{\delta n}$ in the previous footnote and Dunne, Roberts \& Samuelson (1989).

${ }^{29}$ See Dunne, Robertson and Samuelson (1989).

${ }^{30}$ The rationale is that large firm is one that has received the favorable signals in the past, so the next signal is less likely to be so unfavorable to induce exit.Regarding the effect of firm age, the older firms have relatively precise estimates of their efficiency, so $x_{t+1}^{*}$ should be close to $x_{t}^{*}$ and thus more likely far from the exit threshold $\bar{x}_{t}$.
} 
Allowing for firm exit the firm expected growth rate, $E\left(\frac{q_{t+1}^{*}-q_{t}^{*}}{q_{t}^{*}}\right)=g$ can be expressed as: ${ }^{31}$

$$
g=g_{s} P_{s}+g_{\text {exit }}\left(1-P_{s}\right)=g_{s} P_{s}-\left(1-P_{s}\right)
$$

where $g_{s}$ is the mean growth rate of surviving firms, $P_{s}$ is the probability that a randomly drawn firm will survive and $g_{\text {exit }}$ is the mean growth rate of exiting firms, equal to -1 . Equation (3) explains why empirical studies relying only on the surviving firms might lead to misleading conclusions. Suppose that foreign presence (measured by $z$ ) increases the growth rate (or productivity) of surviving firms, so $\partial g_{s} / \partial z>0$. This result provides a useful inference only if the foreign presence does not change also the probability of firm survival, $P_{s}$. If foreign presence reduces $P_{s}$, so $\partial P_{s} / \partial z<0$, then the positive effects of foreign presence found on survivors will be overestimated, because $\partial g / \partial z=\left(\partial g_{s} / \partial z\right) P_{s}+\partial P_{s} / \partial z\left(1+g_{s}\right)$ and $P_{s}<1$. On the other hand, if $P_{s}$ increases with foreign presence, the overall positive effect of foreign presence might be actually higher than the effect found by looking only at survivors.

\subsubsection{Dominant firm behavior and equilibrium}

As in Jovanovic (1982), I assume that a deterministic downward sloping market demand function $Q_{t}^{m}\left(p_{t}\right)$ is given for each time $t$, so all the demand changes are foreseen. Jovanovic describes a perfect foresight equilibrium in which the existing firms and potential entrants assume that a specific price sequence will appear and their behavior in fact gives rise to this price sequence. I make a similar assumption in the sense that in my model a dominant firm moves first, determines its long-run goals in terms of the price sequence $p$, and makes it public at the beginning of the game. $^{32}{ }^{33} \mathrm{I}$ also assume that the dominant firm cannot commit to a price sequence, so the announced price sequence must be subgame perfect to be an equilibrium price sequence.

After the price sequence is announced, the fringe firms make their output and thus also exit decisions. In equilibrium the residual demand of the dominant firm, $Q_{t}^{D F}(p)$ can be expressed as the total market demand $Q_{t}^{m}\left(p_{t}\right)$ minus the total supply of competitive fringe, $Q_{t}^{C F}(p)$ :

$$
Q_{t}^{D F}(p)=Q_{t}^{m}\left(p_{t}\right)-Q_{t}^{C F}(p)
$$

Though fringe firms face individual uncertainty, there is no aggregate uncertainty, so the CF supply is deterministic in each period t. (See Appendix A2). Having inferred total supply of the competitive fringe, $Q_{t}^{C F}(p)$, the dominant firm chooses the equilibrium price sequence,

\footnotetext{
${ }^{31}$ See Dunne, Robertson and Samuelson (1989) and Sun (2002). Note, this equation is the same as the standard textbook equation for unconditional mean in the tobit model for corner solution (or censored data) problem, where the censoring threshold is at the growth rate $=-1$.

${ }^{32}$ Equivalently the problem could be specified such that the DF chooses output sequence $\left\{Q^{D F}\right\}_{t=0}^{\infty}$ instead of price sequence. The choice of a price sequence directly makes a game more transparent.

${ }^{33}$ In the CR many MNCs entered via privatization process, which often required that foreign investor makes public its future plans, regarding e.g. the employment, capital investments or restructuralization steps.
} 
$p=\left\{p_{t}\right\}_{t=0}^{\infty}$, to maximize the net present value of its profits:

$$
N P V(p) \underset{\left\{p_{t}\right\}_{t=0}^{\infty}}{=} \sum_{t=0}^{\infty} \delta^{t}\left\{p_{t}\left[Q_{t}^{m}\left(p_{t}\right)-Q_{t}^{C F}\left(\left\{p_{t}\right\}_{t=0}^{\infty}\right)\right]-T C\left(Q_{t}^{m}\left(p_{t}\right)-Q_{t}^{C F}\left(\left\{p_{t}\right\}_{t=0}^{\infty}\right)\right)\right\}
$$

where $T C\left(Q_{t}^{m}\left(p_{t}\right)-Q_{t}^{C F}\left(\left\{p_{t}\right\}_{t=0}^{\infty}\right)\right) \equiv T C\left(Q_{t}^{D F}\right)=c\left(Q_{t}^{D F}\right) f\left(\theta^{D F}\right)$ represents the total cost of the dominant firm, $c($.$) is a convex cost function, and f$ is the same function as in case of fringe firms. $\theta^{D F}$ is the true efficiency of the dominant firm, which is already known, so $f\left(\theta^{D F}\right)$ is deterministic. This assumption is consistent with the notion that the foreign firm has already operated for a long time in the competitive environment so it has learnt its true efficiency. ${ }^{34}$ This is especially true in comparison to domestic firms in transitional economy such as the Czech Republic, where competitive environement was installed only after the start of transition. In addition, I assume that at each output level $c^{\prime}(q)<C^{\prime}(q)$ and $f\left(\theta^{D F}\right)<x_{0}$, where $C(q)$ and $x_{0}$ are the cost function and the prior of the fringe firms (see footnote 25), because the dominant firm has a better production technology (at least upon entry) due to the competitive advantages described earlier.

Since both $f\left(\theta^{D F}\right)$ and $c($.$) are known, the dominant firm does not face any cost uncertainty. { }^{35}$ So the stream of expected profits is equal to the stream of actual profits. However, I account for the DF's general uncertainty associated with operations in the foreign market (e.g. exchange rate volatility, political and other country risks), via a discount rate. I assume that the dominant firm has a much lower discount factor $\delta$ (i.e. higher interest rate) than $\rho$, the discount factor of competitive fringe firms (see Appendix, A2). Given equation (5), for any $t$ then $p_{t}$ must satisfy:

$$
\begin{aligned}
\frac{\partial N P V}{\partial p_{t}} & =\delta^{t}\left[p_{t}\left(\frac{\partial Q_{t}^{m}}{\partial p_{t}}-\frac{\partial Q_{t}^{C F}(p)}{\partial p_{t}}\right)+\left(Q_{t}^{m}\left(p_{t}\right)-Q_{t}^{C F}(p)\right)-\frac{\partial T C}{\partial Q_{t}^{D F}}\left(\frac{\partial Q_{t}^{m}}{\partial p_{t}}-\frac{\partial Q_{t}^{C F}(p)}{\partial p_{t}}\right)\right] \\
& +\sum_{i=t+1}^{\infty} \delta^{i}\left[p_{i}\left(-\frac{\partial Q_{i}^{C F}(p)}{\partial p_{t}}\right)+\frac{\partial T C}{\partial Q_{i}^{D F}} \frac{\partial Q^{C F}(p)}{\partial p_{t}}\right] \\
& +\sum_{i=0}^{t-1} \delta^{i}\left[p_{i}\left(-\frac{\partial Q_{i}^{C F}(p)}{\partial p_{t}}\right)+\frac{\partial T C}{\partial Q_{i}^{D F}} \frac{\partial Q_{i}^{C F}(p)}{\partial p_{t}}\right]=0
\end{aligned}
$$

The first squared bracket term in equation (6) represents the within period effect of price on profits, namely the marginal revenue of the dominant firm, conditional on the response of the competitive fringe, minus the marginal cost of the dominant firm in period $t$. The other two terms represent "predatory" or "strategic" effects across periods. These effects arise because the total supply of competitive fringe at time $t$ does not depend only on price $p_{t}$, but on the whole price sequence $p$, due to exit and entry of the fringe firms. The first sum represents the impact

\footnotetext{
${ }^{34}$ De Backer (2002) also argues that Jovanovic learning type models are more suitable for domestic firms than for MNC's, because MNC's already have learnt their (relative) efficiency at home market and can transfer this learning experience across the borders. This also enables them to enter the foreign markets at more efficient scale.

${ }^{35}$ I make this theoretical simplification because introducing ex-ante the cumulative shock such as $u_{t}$, or learning process (similar to the one for fringe frims) into the optimization process of DF would lead to stochastic prices, and complicate the analysis without generating any important insights for the empirical purpose of this paper.
} 
of the change in a price $p_{t}$ on the total supplies of the CF after $t$. The second sum shows impact on the competitive fringe supply before $t$.

Since the equilibrium price sequence must be subgame perfect, both strategic terms can be ignored and set to 0. For example, suppose that the dominant firm announces the price for some future period $t$ that is lower than the static profit maximizing price because it wants to induce excessive exit today. This is an non-credible threat because when period $t$ occurs, after the price is incorporated into the exit decisions of the fringe firms, the dominant firm would want to charge its time $t$ profit maximizing price. Hence the low price cannot be part of an equilibrium price sequence. Similarly, for the first sum, which represents a typical predatory intent - a firm may charge a lower price today and sacrifice current profits in order to gain larger market share tomorrow and charge higher price in the future. However, since firm exit and entry decision depend on the whole price sequence not just current price, higher prices in the future will reduce fringe exit decisions today. In addition, higher future prices will attract new entrants, and reduce future prices. ${ }^{36}$ Hence announcing a current price $p_{t}$ that is lower than the optimal price in the one period problem would again be a non-credible threat. ${ }^{37}$

The elimination of the predatory effects transforms problem (5) into the sum of time separable one-period optimization problems and condition (6) reduces to:

$$
\frac{\partial N P V}{\partial p_{t}}=p_{t}\left(\frac{\partial Q_{t}^{m}}{\partial p_{t}}-\frac{\partial Q_{t}^{C F}(p)}{\partial p_{t}}\right)+Q_{t}^{m}\left(p_{t}\right)-Q_{t}^{C F}(p)-\frac{\partial T C}{\partial Q_{t}^{D F}}\left(\frac{\partial Q_{t}^{m}}{\partial p_{t}}-\frac{\partial Q_{t}^{C F}(p)}{\partial p_{t}}\right)=0
$$

This implies that the pricing strategy of the DF must at each point in time satisfy:

$$
\left(p_{t}-\frac{\partial T C}{\partial Q_{t}^{D F}}\right)\left(\frac{\partial Q_{t}^{m}}{\partial p_{t}}-\frac{\partial Q_{t}^{C F}(p)}{\partial p_{t}}\right)=-Q_{t}^{D F}\left(p_{t}\right)
$$

Total differentiation of condition (4) yields that $\left(\frac{\partial Q_{t}^{m}}{\partial p_{t}}-\frac{\partial Q_{t}^{C F}(p)}{\partial p_{t}}\right)=\frac{d Q_{t}^{D F}\left(p_{t}\right)}{d p_{t}}<0$ (the slope of the residual demand for DF). ${ }^{38}$ Substituting this into equation (8) and expanding by $p_{t}$ gives:

$$
\frac{d p_{t}}{p_{t}}=\frac{-\left(p_{t}-T C^{\prime}\right)}{p_{t}} \frac{d Q_{t}^{D F}}{Q_{t}^{D F}}
$$

where $T C^{\prime}=\frac{\partial T C}{\partial Q_{t}^{D F}}>0$, since $c\left(Q_{t}^{D F}\right)$ is an increasing function. This represents a standard price cost margin, measured by the Lerner Index: $\frac{p-M C}{p}=-\frac{1}{\text { elasticity of residual demand of } D F}$. If the DF does not have any market power then $p_{t}=T C^{\prime}$ and its effect on the market price is zero.

\footnotetext{
${ }^{36}$ Usual arguments from industrial literature against predation are:1) it is not sure how long the low price must be imposed to achieve excessive exit; 2) the DF may not want to implement predation, because profits today are worth more than profits tomorrow, especially with low discount rate assumed here.

${ }^{37}$ Hooley et al.(1996) analyze the marketing capabilities of Hungarian firms and find that firms with foreign participation usually focus on superior quality rather than lower prices. Kumar(1991) draws similar conclusions using data from India.

${ }^{38} d Q_{t}^{D F}=\frac{\partial Q_{t}^{m}}{\partial p_{t}} d p_{t}-\frac{\partial Q_{t}^{C F}(p)}{\partial p_{t}} d p_{t}-\sum_{i \neq t} \frac{\partial Q_{i}^{C F}(p)}{\partial p_{i}} \frac{\partial p_{i}}{\partial p_{t}} d p_{t}$, where $\frac{\partial p_{i}}{\partial p_{t}}=0$, since as described above the problem is time separable. Then $d Q_{t}^{D F}=\left(\frac{\partial Q_{t}^{m}}{\partial p_{t}}-\frac{\partial Q C F(p)}{\partial p_{t}}\right) d p_{t}$.
} 
Writing equation (9) in discrete time implies that the percentage change in prices between $t+1$ and $t$ is equal to the growth rate in the output of the DF between $t+1$ and $t$, multiplied by its price markup at time $t, m_{t}$, so: $\frac{p_{t+1}-p_{t}}{p_{t}}=-m_{t} \frac{\left(Q_{t+1}^{d}-Q_{t}^{d}\right)}{Q_{t}^{d}}$. Hence given a markup at time $t$ a larger percentage increase in the output of the dominant firm will induce a larger percentage decline in prices the next period. Substituting this result into equation (2) the model implies that under the $\mathrm{DF} / \mathrm{CF}$ industry structure the growth rate of a domestic/fringe firm follows:

$$
\frac{q_{t+1-}^{*} q_{t}^{*}}{q_{t}^{*}}=-k m_{t} \frac{\left(Q_{t+1}^{d}-Q_{t}^{d}\right)}{Q_{t}^{d}}-k\left(\text { age }_{t}, \text { size }_{t}\right)+k u_{t+1}+i n d \times \text { trend } .
$$

The last term represents the cross products of industries and time trend, to take into account that demand $Q_{t}^{m}\left(p_{t}\right)$ varies over time.

Empirically, the growth rate in the output of the dominant firm captures a dynamic crowding out effect. Ceteris paribus, equation (10) predicts that a greater expansion of foreign output over time reduces the output of individual domestic firms and their growth rates. The coefficient of foreign growth rate, $-k m_{t}$, represents the elasticity of individual domestic firm output $\left(q_{t}^{*}\right)$ with respect to the foreign output, so the relationship between growth rates can be explained in terms of production elasticity. Relating firm growth rates to exit, higher foreign growth rates will also increase the exit rates of domestic firms. However, if foreign competition has only a one-time effect, i.e. crowding out is static, there should be only a one-time reduction in the output of domestic firms at the time of foreign entry. To test the static crowding out effect, empirically, I introduce a dummy for the year of foreign entry into a particular industry into both the equation for domestic firm growth (10) and exit/survival.

In the next section, I discuss the measurement of technology spillovers represented by technology shock $u_{t+1}$. The technology shock in this model is treated as a positive externality/spillover affecting domestic firm cost function. The rationale is that spillovers are by definition unintentional, so $u_{t+1}$ is neither a choice variable of the dominant or domestic firm. However, the technology spillovers enter the optimization process of the DF indirectly via higher values of the

total CF supply, $Q_{t}^{C F}(p)$. Specifically, positive technology spillovers increase $Q_{t}^{C F}(p)$ and thus reduce the market power of the dominant firm. Hence the implicit prediction of the model is that in the long-run as the technology of domestic firms converges to foreign technology due to accumulation of plausible technology shocks, the market power and thus price markup of the dominant firm, $m_{t}$, should diminish over time. Then the negative crowding out effect should also diminish over time as well. How long this takes is an empirical question.

\section{Technology spillovers and technology shocks}

While the "competitive/crowding out" effect occurs via changes in prices associated with foreign output changes, the positive "technology spillovers" enter via the technology shock $u_{t+1}$. Since $u_{t+1}$ is an exogenous shock, the model does not provide a direct relationship between $u_{t+1}$ and other parameters. However, the literature on technology transfer and technology spillovers 
suggest that spillovers might be correlated with different firm and industry characteristics. I develop my measures of technology spillovers based on the arguments from this literature.

Blomström et. al (2000) refer to technology spillovers as contagion or demonstration spillovers. These spillovers are believed to arise through business contracts, employment of workers who previously worked for a foreign firm or simply through the observation of the operations and management practices of a nearby foreign firm. ${ }^{39}$ Consequently, Wang and Blomström (1992) argue that technology spillovers should be proportional to the extent of foreign presence in the domestic market. Hence, I measure the intra-industry technology spillovers by the foreign employment share in the industry $(E S) .{ }^{40}$ As Haskel et al. (2001) note, this measure has two advantages, namely: 1) it measures how prevalent the foreigners are in the industry scaling for the overall industry size, 2) it captures the interpersonal contact that is emphasized by the spillover theories. ${ }^{41}$ Specifically, the more people work in the foreign sector, the more people can communicate how foreign firms operate or how they are organized, which increases the chances for technology leakages. Hence, larger foreign employment shares should contribute to larger firm-level technological shock $u_{t+1}$.

A domestic firm can also benefit from intra-firm technology spillovers if it has some foreign shareholders. ${ }^{42}$ One can expect that firms with foreign participation will have much easier access to foreign technologies than firms without foreign partners through their direct ownership ties. This in turn might contribute to larger technology shock $u_{t+1}$. To capture this effect I include the percentage of foreign direct ownership in a domestic firm (FORdirect) among my regressors.

The positive effect of firm innovation on its growth and survival has been analyzed in several studies. ${ }^{43}$ The firm innovation determines the firm "absorptive capacity", emphasized by the technology transfer literature. ${ }^{44}$ This literature implies that domestic firms must have certain level of technological advancement (in house expertise), in order to better absorb an advanced technology. I use the firm's intangible asset ratio (intang) to control for firm absorptive capacity and innovation. ${ }^{45}$ The firms with higher values of intang (larger absorptive capacity) should more easily imitate and utilize foreign technology and thus have larger technology shock $u_{t+1}{ }^{46}$

Finally, both the technology transfer literature and FDI spillovers studies emphasize that the magnitude of technology spillovers depends on the "technology gap" (henceforth gap), i.e. the differences in the technological capabilities between domestic and foreign firms. ${ }^{47}$ The technology

\footnotetext{
${ }^{39}$ By technology one should understand technology in a broad sense, including not only products and production information, but also distribution networks, management \& marketing skills, etc.

${ }^{40}$ Görg \& Strobl (2000) and Aitken \& Harrison (1999) also used foreign employment share based measures.

${ }^{41}$ The importance of interpersonal contact for technology diffusion was already discussed by Findlay (1978).

${ }^{42}$ Aitken \& Harrison (1999), Haddad \& Harrison (1993) or Kinoshita (2000), analyzing technology spillovers and firm productivity in the CR, also distinguished the intra-firm and intra-industry spillovers.

${ }^{43}$ See e.g. Audretsch (1991), Pakes and Ericson (1987), Jovanovic \& MacDonald (1994) or Mansfield (1962).

${ }^{44}$ See Cohen and Levinthal (1990) and Mowery et. al(1996).

${ }^{45}$ I scale intangible assets by total assets since larger firms probably have also a larger intangible assets.

${ }^{46}$ Several studies use the ratio, $\frac{R \& D \text { expenditures }}{\text { sales }}$, as a measure of the firm "absorptive capacity". However, as Mowery et al. (1996) discuss, R\&D expenditures measure the inputs not an output of the innovative process. Thus many recent studies use patent citations as a more appropriate measure of innovative output. Unfortunately, there is no information on firm patents in my data. However, according to the Czech accounting act, intangible assets should primarily reflect the value of a firm's patents and accumulated know-how.

${ }^{47}$ See Findlay (1978), Sjöholm (1999), Caves (1999), Oxley (1997), Haddad \& Harrison (1993) .
} 
transfer literature argues that the large gap between technology donor and recipient increases the costs of the technology transfer and reduces the likelihood of technology transfer. On the other hand, some FDI spillovers studies (e.g. Haddad \& Harrison, 1993; Haskel et al., 2001; Sjöholm, 1999) conclude that the larger gap represents more opportunities for technology exchange and thus more technology spillovers can be generated. ${ }^{48}$ Which of these effects dominates is an empirical question. I therefore make $u_{t+1}$ a function of the firm technology gap and its interaction with foreign employment share to control for the possibility that the technology gap facilitates/inhibits intra-industry technology spillovers. I measure gap by the absolute value of the difference between the firm's intangible assets ratio and the intangible asset ratio in the foreign industry segment. The absolute value reflects how much the technology of domestic firm is (dis)similar from foreign technology (I define the construction of all variables in section 6).

In the theoretical model $u_{t+1}$ is assumed to be firm specific and observable at the beginning of $t+1$. Hence, in my empirical work I allow for unobserved firm effects, $\mu_{i}$, and all the technology variables are measured at time $t$. Assuming that correlations between the discussed variables and $u_{t+1}$ can be approximated by a linear functional form, the technology shock of a domestic firm $i$ in the industry $j$ can be written as follows:

$$
u_{i j t+1}=\alpha_{1} E S_{j t}+\alpha_{2} \text { FORdirect }{ }_{i j t}+\alpha_{3} \text { intang }_{i j t}+\alpha_{4} g a p_{i j t}+\alpha_{5} E S_{j t} * g a p_{j i t}+\mu_{i}
$$

\section{Data description}

I use firm-level panel data for the Czech Republic during 1994-2001, from the Amadeus database (TOP 1 million). The Amadeus database contains firm balance sheet data for Western, Central and Eastern Europe and Russia. For the Czech Republic, the data are based on the firm accounts filed with the Tax Office and Business Registrar. My data come from two sources. The year 1994 is from the Amadeus DVD. ${ }^{49}$ The years, 1995-2001, are from the Amadeus online version. ${ }^{50}$ For the year 1993 many observations were missing, most likely due to the break-up of the Czechoslovak Republic into the Czech and Slovak Republic. Since there might have been filing problems and miscodings, I have decided to exclude this year from my analysis.

The firms included in Amadeus must satisfy at least one of the 3 criteria: 1) operating revenue of at least $1 \mathrm{mil}$. ecu, 2) total assets of at least $2 \mathrm{mil}$. ecu, 3) number of employees at least 10. So firms of all sizes are included, except for very small firms and there is also a significant number of single entrepreneurs. The database provides firm registration information (firm ID, date of incorporation, city, region and other characteristics), balance sheet items, profit and loss accounts, different industry classifications, information about subsidiaries and individual firm shareholders. In addition, the name and country of the ultimate owner, i.e. the firm at the

\footnotetext{
${ }^{48}$ This view is similar to the convergence hypothesis in the macroeconomic growth theory, where the technology gap relates to more or less developed countries not a firm, but the underlying ideas are the same. Findlay (1978) points out that the idea of relative backwardness is already associated with Veblen (1915) and Gerschenkron (1962).

${ }^{49}$ This DVD contains the data for period 1993-1998, but the early years are reported for smaller set of firms.

${ }^{50}$ I made three data downloads at different times: 1) March 2002, 2) January 2003 and 3) February 2003.
} 
top of the ownership chain are provided. I use these to classify domestic vs. foreign firms (see below). Unfortunately, Amadeus does not provide full time series of ownership data (ultimate or foreign direct), only ownership related to the last balance sheet filed by the company is available. However, my 4 different data sources helped me not only to increase the sample size, but mainly to maximize information on ultimate ownership and gain variation in my foreign direct ownership variable (FORdirect) (exact steps of combining the data can be provided on request). ${ }^{51}$

I use 3-digit primary USSIC mainly because higher digit classification leaves extremely small number of observations per industry. The main reason is that the CR is a small country, population cca. 10 mil., so there are not so many firms per 4-digit or more disaggregated industries.

Unfortunately, the data are very unbalanced, with much miscodings ${ }^{52}$, and a number of small firms with completely missing balance sheet items (only firm ID, name, address etc. are provided). Merging the data from my different sources created the starting sample of 11545 firms. From these I excluded all agriculture related industries (primary USSIC <100), because foreigners can not own soil in the CR, and governmental, legal, educational, religional, health services and other non-profit organizations. These sectors are mostly under government ownership, so foreign presence is either excluded by law or very rare. This reduced sample to 10335 firms, which I used in classification procedures to determine whether a firm is foreign or domestic (see below). The elimination of firms with the miscodings reduced sample to 10157 firms in 257 3-digit industries (66080 obs.). Then I performed additional balance sheet cleaning, missing data fillings and outlier exclusions (see Appendix B2), which left a sample of 9986 firms (61438 obs.). ${ }^{53}$ From these 5235 firms were classified as domestic, 1398 as foreign and 3353 were non-classified firms. Table C2 compares means for several performance measures between classified (both domestic and foreign) and non-classified firms. The data show that non-classified firms are significantly smaller in most size measures, operate on zero profit margin and in industries with higher number of firms. So I treat non-classified firms as domestic ones, since these seem to be small Czech start-ups. ${ }^{54}$

Since the model gives predictions for domestic firms in the competitive fringe I restrict my empirical analysis only to 142 competitive industries, i.e. industries with at least 10 domestic firms during entire sample period before balance sheet cleaning. ${ }^{55}$ There are 11 industries without foreign presence during entire sample period (see Appendix B2) and 131 industries with foreign presence. The 142 industries are listed in Appendix, Table C4.

The final sample I use to estimate firm growth consists of 5705 domestic firms (20462 obs.) and the exit sample consists of 6291 domestic firms (24733 obs.). In both cases there is cca. 1300

\footnotetext{
${ }^{51} \mathrm{My}$ four data sources provide ownership information for approximately these years:1) DVD(1993-1998)- most firms ownership related to 1998 balance sheets; 2) download in March 2002 - related to 2000 balance sheets or earlier; 3) January/February 2003 - balance sheets in 2001or earlier.

${ }^{52}$ Balance sheets were reported many years before the date of firm foundation, duplicated observations etc.

${ }^{53}$ Out of these, however, only 34544 obs. have reported sales.

${ }^{54}$ I expect that if a firm had a foreign ultimate owner this information would be filed and reported in the database. However, I can not exclude the possibility that some of these firms can have mixed ownership. Therefore, in empirical analyses I allow for separate coefficients on the variables of the main interest and at the end repeat the analysis for subsamples based on according \% foreign direct ownership.

${ }^{55}$ First there were 143 industries, but I dropped industry 609 (8 obs.), since $F G>140$ (i.e. 14000\%), which is an outlier compared to other 142 industries, where FG is in a range from -1 to 42.2 .(see Table 1.2-1.3)
} 
foreign firms (unbalanced), which enter the calculation of foreign industry variables. The exit sample is larger, because some firms have either missing sales in 2001, or do not have consecutive observations, so the growth rates are missing. ${ }^{56}$ Tables 1.3. and 1.4. show summary statistics for regressors in growth and exit sample respectively.

\section{The classification of domestic vs. foreign firms}

I classify a firm as domestic if its ultimate owner is Czech, and as foreign if the country of ultimate owner is other than the CR (see Appendix, B4 for determination of ultimate ownership). I prefer ultimate ownership instead of sum of foreign direct ownerships, used by many studies, because this sum does not reflect who has an ultimate control or a "final word" in the firm decisions. E.g. suppose that a firm has 3 foreign shareholders, each with a stake of $18 \%$, so a in total a firm has $54 \%$ of foreign direct ownership and $46 \%$ is owned by a single Czech shareholder. Based on a majority rule, the firm would be classified as foreign. However, I suggest that degree of control, participation at stock holder meetings, and thus effect on firm performance depend on the size of individual ownership stakes. Thus in the above example one can expect that the single Czech owner has bigger influence on firm organization. Moreover, using the total foreign direct ownership the question is what percentage should be taken as a proper benchmark. ${ }^{57}$ Nevertheless, when I compared the number of firms classified as foreign by ultimate ownership with the number of firms classified as foreign by the $50 \%$ of total foreign direct ownership, the numbers matched from 92.2\%-97.5\% across 4 data sources. Hence, I believe that the empirical results would be similar to those I present here if the classification foreign vs. domestic was based on $50 \%$ of total foreign direct ownership.

Though ultimate ownership data are missing for many firms, having 4 different sources allowed me maximize the data on ultimate ownership by combining it across time. Comparing the ultimate ownership data across the 4 sources, for those firms which had ultimate ownership available in more than one source, I found that ultimate ownership data matched at more than $90 \%$ for all online downloads and online downloads matched DVD information about $62 \%$ of the time. These comparisons show that ultimate ownership does not change so much over time. Due to this reason, as well as a lack of reliable time series on firm ultimate ownership, I simply supplemented the ownership information available in different data sources with each other. ${ }^{58}$ As a result, my classification of foreign vs. domestic firm does not vary over time.

\footnotetext{
${ }^{56}$ Missing observations are treated as censored not as exits. I re-estimate firm exit only for the growth subsample, but the results are similar to those from exit sample, so selection bias due to missing sales is unlikely.

${ }^{57}$ Some studies use $50 \%$ to classify foreign firms, others use $20 \%$ or $25 \%$ thresholds. Probably the most appropriate classification would be based on the distribution of shareholders' votes, but such data are unavailable.

${ }^{58}$ I took as a starting benchmark the ultimate ownership from download in March 2002 (with the last balance sheets for year 2000 or earlier), because there were the least missing observations in the country of ultimate owner and I filled the missing observations with the ultimate ownership data from the other 3 sources (exact steps of filling the data can be provided on request).
} 


\section{Variable definition and empirical specification}

Substituting equation (11) into growth equation (10) and adding other controls that I explain below, the empirical equation for the domestic firm growth rate is as follows:

$$
\begin{aligned}
& \text { Growth }_{i j t+1}=\beta_{0}+\beta_{1} F G_{j t+1}+\beta_{2} S T A T I C+\beta_{3} a g e T_{i j t}+\beta_{4} \text { size }_{i j t}+\beta_{5} a g e T_{i j t}^{2}+\beta_{6} \text { size }_{i j t}^{2}+ \\
& \beta_{7} A S_{i j t}+\beta_{8} E S_{j t}+\beta_{9} \text { FORdirect }_{i j t}+\beta_{10} \text { intang }_{i j t}+\beta_{11} \text { gap }_{i j t}+\beta_{12} \text { ESgap }_{i j t}+ \\
& \beta_{13} \text { solvency }_{i j t}+D 89+\sum d_{t}+\sum d_{j}+\sum d_{j}{ }^{*} \text { trend }+\sum \text { region }+\left(\mu_{i}+e_{i j t+1}\right)
\end{aligned}
$$

where $i$ indexes a domestic firm, $j$ an industry, and $t$ time. Since firm exit is directly linked to firm growth, the same variable definition applies also to empirical exit/survival model.

Growth $_{i j t+1}$ : firm growth rate between $t+1$ and $t$ measured by sales revenues as $\left(\frac{\text { sales }_{t+1}-\text { sales }_{t}}{\text { salest }_{t}}\right)$. If a firm exits between $t+1$ and $t$ then sales $s_{t+1}=0$ and the growth equals to $-1 .{ }^{59}$

$\mathbf{F G}_{j t+1}$ : the growth rate of foreign industry sales, $\left(\frac{\sum_{k}^{F} \text { sales }_{k j t+1}-\sum_{k}^{F} \text { sales }_{k j t}}{\sum_{k}^{F} \text { sales }_{k j t}}\right)$, where $k=$ $1,2 \ldots F$ are all foreign firms in the industry $j$. For industries/years without foreign presence $\mathrm{FG}=0 .{ }^{60}$ The model above predicts that the percentage change in prices equals to the percentage change in the foreign (dominant firm) output multiplied by its profit margin. However, I do not have output data, only sales revenues, which already include prices. So I use the simple growth rate in foreign sales revenues to approximate this multiplicative term. FG measures the competitive or dynamic crowding out effect between foreign and domestic firms, so it is expected to have a negative (positive) effect on domestic firm growth and survival (exit rate). (Below I state the expected signs on firm survival. The predictions for exit rates have the opposite sign).

STATIC: dummy $=1$ in the first year I observe the foreign firms in an industry (before data cleaning). The reason is that I observe foreign entry in my data only for 4 industries. In other industries foreign firms are already "in" during my sample period. Though it is not an exact measure of foreign entry, it should be close to the true entry year given the timing of the privatization process during which MNCs entered the CR. ${ }^{61}$ This variable measures static crowding out effect and should have negative effect on firm growth and survival.

ageT $_{i j t}$ : firm age measured from the start of transition in 1989 if a firm was founded before 1989. Otherwise, ageT is the firm true age, measured from the year of firm incorporation. As dis-

\footnotetext{
${ }^{59}$ Since my sample ends in 2001 , the effective sample period is 1994-2000.

${ }^{60}$ There are no industries with foreign presence and $F G=0$. In 4 industries however, (3-digit USSIC: 239. 289, $343,794)$ foreign entry appears during my sample period. In these cases (146 observations) the entry growth rate would be infinite, so I set $F G=2$, based on the alternative formula for growth rates: $\left(y_{t+1}-y_{t}\right) /\left(y_{t+1}+y_{t}\right) / 2$.

${ }^{61}$ As Kocenda and Svejnar (2003) describe there were 2 waves of privatization: 1991-1992 (small scale) and 1991-early1995 (large scale privatization). They discuss that big changes in ownership still appeared in 1995-1996 due to unofficial reallocation of shares across the new owners. Table below shows that in most cases $S T A T I C=1$ in year 1994 or 1995, which is around the time when the major privatization process was completed and stable ownership shares were determined:
}

\begin{tabular}{|l||l|l|l|l|l|l|l|}
\hline year & 994 & $' 95$ & $' 96$ & 97 & 9 & \multicolumn{1}{c|}{99} & '00 \\
\hline \hline STATIC $=0$ & 21 & 2252 & 3069 & 3642 & 3799 & 4128 & 1803 \\
\hline STATIC $=1$ & 1412 & 211 & 30 & 42 & 40 & 13 & 0 \\
\hline observ. & & & & & & & 20462 \\
\hline
\end{tabular}


cussed earlier, before 1989 competitive environment was missing, so I expect that firm operations during the socialism did not contribute to firm's learning process about its efficiency. ${ }^{62}$

size $_{i j t}$ : firm size, measured by firm sales revenues. ${ }^{63}$ According to the model both firm age and size should have negative impact on firm growth, but positive on survival.

$\mathbf{A S}_{i j t}$ : the product of firm size and ageT. This term together with the squared terms of firm age and size are included to allow for non-linear effects (see e.g. Evans (1987)). ${ }^{64}$

$\mathbf{E S}_{j t}$ : the foreign employment share in the industry $j, \frac{\sum_{k}^{F} \text { employment }_{k j t}}{\sum_{h}^{N} \text { employment }_{h j t}}$, where $h=1,2, . . N$ represent all firms in the industry. ${ }^{65}$

FORdirect $_{i j t}$ : the percentage of firm foreign direct ownership, defined as a sum of percentage ownerships across all foreign shareholders in a domestic firm. Both ES and FORdirect should have positive impact on domestic firm growth and survival.

$\operatorname{intang}_{i j t}$ : firm intangible asset ratio defined as $\left(\frac{\text { intangible assets }_{i j t}}{\text { total assets }_{i j t}}\right)$. Measuring firm absorptive capacity it should have a positive effect on firm growth and survival.

$\operatorname{gap}_{i j t}$ : domestic firm technology gap $\left(\right.$ gap $\left._{i j t}\right)$, defined as $\mid$ intang $_{i j t}-\frac{\sum_{k}^{F} \text { intangible assets }_{k j t}}{\sum_{k}^{F} \text { total assets } s_{k j t}} \mid$ across all foreign firms $k=1,2 \ldots F$ in the industry $j$. As I already discussed in section 4 this variable can have positive or negative impact depending on which theory one focuses on.

$\mathbf{E S g a p}_{i j t}$ : the cross effect between $E S$ and gap $_{i j t}$. If larger technology difference between domestic and foreign firms makes technology spillovers more costly then this term should have negative effect on firm growth and survival.

solvency $_{i j t}$ : the solvency ratio $\left(\frac{\text { shareholders funds }_{i j t}}{\left.{\text { total } \text { assets }_{i j t}}\right)}\right.$ as reported in the Amadeus database. The numerator is the sum of shareholders' capital and other funds, including reserves. The theoretical model above focuses on the self-selection and competitive effects, but as finance literature suggests that especially growth of small firms often depends on the availability of internal finance, resp. retained earnings. ${ }^{66}$ Lízal and Svejnar (2002) also document that the Czech firms financing investments internally had to pay it from retained profits. On the balance sheets the retained profits are part of firm reserves, reported under the shareholders' funds. So I use solvency ratio to control for availability of firm internal finance. ${ }^{67}$ The solvency should have a positive impact on firm growth, but only if firms are financially constrained (i.e. can not obtain the external funds). If the domestic firms do not face credit constraints, the solvency ratio should have no effect on firm growth. I also expect positive effect on firm survival, because more internal resources help

\footnotetext{
${ }^{62}$ I estimate the main specifications with both: age $T$ and firm actual age, but the results do not change.

${ }^{63}$ This is a standard measure of firm size in industrial organization literature. Since the sales revenues reflect variation in quantity as well as prices, which may be the result of changes in product quality not a competition, sales also control for firm product quality changes.

${ }^{64}$ The non-linear terms also control for potential heteroscedasticity of growth rates due to firm age and size.

${ }^{65}$ In industries without foreign presence $E S=0$. Both $E S$ and $F G$ are computed after the deletion of obvious miscodings and variable cleaning on sales and employment, but before data cleanings on other variables get the most precise representaiton of foreign industry part.

${ }^{66}$ See Carpenter and Petersen (2002) or Butter and Lintner (1945) for earlier evidence.

${ }^{67}$ By definition the shareholder's funds and debt must equal to total assets. Then the solvency ratio is the inverse measure of debt/assets ratio used in some studies as a measure of financial distress (or financial constraints) see e.g. Harrison \& McMillan(2001).Other finance studies use cashflow/(total assets) to identify the financing constraints. When I used this ratio as an alternative control for financial constraints the growth results were similar. However, Kaplan \& Zingales (1997) question whether cashflow reliably measures financial constraints.
} 
to delay or prevent firm bankruptcy.

$\mathbf{d}_{t}, \mathbf{d}_{j}$ and region: annual, industry and 7 regional dummies, respectively. ${ }^{68}$ Annual dummies control for the macroeconomic changes in demand, inflation, and overall institutional reforms. Industry and region dummies control for time invariant industry and region effects such as specific input requirements, regulation and other differences across industries and regions. These dummies also control for the potential endogeneity of FDI presence. Foreign firms may enter more profitable industries/regions or those with larger FDI incentives, or they may enter at a certain year, after some institutional changes were passed. ${ }^{69}$

$\mathbf{d}_{j}$ *trend: cross effect between industry dummies and time trend to control for time varying industry effects and the industry demand changes on both the domestic and export market. ${ }^{70}$

D89: dummy=1 if a firm was founded before 1989 (start of transition) to control for potential subsidy effect. Such firms are former state owned enterprises (SOEs) many of which were subsidized even after $1989 .{ }^{71}$ I expect a positive effect on firm survival, because these subsidies were primarily designed to prevent firm failures and unemployment. However, I expect no or even negative effect on firm growth. Lízal and Svejnar (2002) conclude that SOEs with an unlimited access to capital are also less profitable. According to the model the less profitable firms should have lower growth rates. Table C3 (Appendix C) confirms that in my data the firms founded before $1989(\mathrm{D} 89=1)$ are larger and less profitable than firms founded after 1989 (D89=0).

As additional controls I include 4 exit type dummies that code whether a firm ever enters the liquidation, bankruptcy, both (bankruptcy and liquidation) or is already out of the Business Registrar. (These dummies are excluded from the exit/survival estimations).

\subsection{Assessing domestic firm exit}

I define firm exit as the year when a firm enters a liquidation or bankruptcy process, whichever started sooner. ${ }^{72}$ The rationale is that when a firm enters the liquidation or bankruptcy process it no longer freely operates in the market, because all the firm decisions, including production and financial responsibilities, are transferred from firm management to an outside person and are

\footnotetext{
${ }^{68}$ The regions are: 1) České Budejovice, 2) Central Bohemia -Ústí nad Labem, 3) Jihlava -Brno - Zlín, 4) Liberec - Hradec Králové, 5) Olomouc -Ostrava, 6) Plzeñ - Karlovy Vary and 7) Prague. In addition, there is a small group of observations for which the region could not be determined. These create a separate group.

${ }^{69}$ E.g. the negotiations about the NATO, EU membership, election result or political risks affect the FDI inflows into transitional countries (see also Svejnar (2002)).

${ }^{70} \mathrm{My}$ sales data include both domestic sales and exports, but I do not have separate data on firm exports. However, since export activities in the $\mathrm{CR}$ are very much industry related these cross effects should control also for the changes in the export demand.

${ }^{71}$ Lízal and Svejnar (2002) conclude that primarily former and current SOEs benefit from soft budget constraints, i.e.willingness of government to provide additional resources or otherwise bail firms out.

${ }^{72}$ By the Czech corporate law a firm enters the liquidation process when it wants to terminate its operations. It can not have any liabilities, and all the remaining assets must be sold (liquidated) before a firm is officially deleted from the Business Registrar. When the process starts the court assigns an outside person responsible the sales of the assets.A firm enters the bankruptcy when some of its creditors file a complaint that a firm is not able to meet its liabilities. In this case the firm's assets must be first used to repay creditors and only after that the remaining assets are sold in the liquidation process. If the liquidation process starts by any chance before the bankruptcy is filed, the liquidation must be temporarily delayed until the creditors are repaid.
} 
supervised by the court. ${ }^{73}$ I rely on the start of a bankruptcy/liquidation process (as opposed to its end) because in the CR these procedures usually take several years and continue much beyond the time when firms stop actively participating in the market. Table $\mathrm{C} 1$ shows that in my data most of these processes still continue in 2003. ${ }^{74}$ The Appendix B3 describes the exact steps I use to verify in the Business Registrar when a firm started the bankruptcy/liquidation process.

In addition, I allow for a 2-year prior exit window to incorporate the delays in reporting and mismatch between calendar and fiscal year over which the balance sheets are filed. ${ }^{75}$ E.g. if a firm started the liquidation in 1999, but the last reported sales in my data are for 1997, I assume that a firm exits in 1997.

In my empirical analyses, I set the variable, Exit $t_{i j t}$, equal to 1 in the year when a domestic firm exits and 0 for all prior years. When Exit $_{i j t}=1$ the growth rate is set to -1 . Firms that survive until the year 2001 have Exit ijt $_{\text {always equal to } 0 .}$

In the end there are 1143 exits in my pre-cleaned data, which gives a 1143/10157=11.3\% exit rate in the original sample. However, out of these only 648 exits satisfy the 2 year exit window (554 exits are in 142 industries used in my analysis). E.g. if a firm enters the liquidation in 2000, but the last reported balance sheet in my data is for year 1995, then such exit is excluded from the exit observations, because of missing data until at least the year 1998 (2000-2 year window). So the last observation from 1995 is treated as censored not an exit. Due to missing observations in my regressors only 273 of the exits remain in my final samples for firm growth (20462 obs.) and exit analysis (24733 obs.). Out of these 273 exits, 77 occur via bankruptcy, 73 via liquidation, 26 are in both processes and 97 firms are out of the Business Registrar.

\section{Estimation of firm growth}

For robustness purposes I estimate the growth equation (12) with different empirical specifications. First, I use linear models: OLS with standard errors corrected for firm-level clusters ${ }^{76}$, fixed and random effects estimators, which control in different ways for firm level unobserved heterogeneity. Then I use Tobit model to control for data censoring. Though, in general the linear

\footnotetext{
${ }^{73}$ Sometimes a firm can produce even after these processes start. In my data there was no firm with sales after the start of the liquidation process and only 3 firms with sales reported after the start of the bankruptcy. In these cases I take the year of last reported sales as the exit year.

${ }^{74} \mathrm{My}$ definition of exit automatically excludes ownership changes due to merger or acquisition if these did not follow a liquidation or bankruptcy process. For the purpose of this study I do not consider these ownership changes to be proper exits because the firms actually continue production under new ownership.

${ }^{75}$ E.g. the balance sheet for 1998 in Amadeus data represents the fiscal year from 01/04/1998 to 31/03/1999.

${ }^{76} \mathrm{I}$ also re-estimate all clustered specifications with clusters on industry-year cells instead of firms. Moulton (1990) shows that if the regression is based on micro units, but the variables of interests are at aggregated level, standard errors in OLS can be underestimated. This might cause the overestimation of crowding out effects and intra-industry technology spillovers. Though the results were similar, there are two disadvantages of such clustering in my case: first, it over-estimates the standard errors of the firm level variables, which are also of potential interesr. Second, the clusters on industry-year allow correlation among observations within the same industry and year, but implicitly impose that firm level observations are uncorrelated across time. Since I find this assumption to be much stronger than the assumption of firm level clusters that the observations are correlated within the firm, but uncorrelated across the firms, I report the results with firm clusters.
} 
models provide inconsistent estimates when dependent variable is censored, they still provide a useful benchmark for the marginal effects near the population means (Wooldridge (2002)).

Both OLS and random effects model treat firm unobserved heterogeneity $\mu_{i}$ as part of the composite error, $\omega_{i j t}=\mu_{i}+e_{i j t}$. While the random effects model provides more efficient estimates if the assumptions of homoscedasticity and equal correlation structure hold, OLS with standard errors corrected for firm level clusters is more robust when these assumptions are violated, because clustering allows for arbitrary correlations between firm level observations and heteroscedasticity. However, both OLS and random effects provide inconsistent estimates if $\mu_{i}$ is correlated with the regressors. In such case fixed effects estimator is preferred. To verify whether such correlation is a problem I compare the random and fixed effects estimates by Hausman test.

Though exit observations with Growt $_{i j t+1}=-1$ are included in all linear models, these do not take into account that the dependent variable is left-censored, so there is a nonzero probability mass at -1 . The censoring appears due to corner solution problem: a firm exits if the potential optimal growth rate $\left(\right.$ Growt $\left.h_{i j t+1}^{*}=X_{i j t}^{\prime} \beta+\mu_{i}+e_{i j t+1}\right)$ would be less than exit growth rate $\widetilde{g}_{t+1}$ (see section 4.4.2.). Then the observed growth rate Growth $_{i j t+1}$ estimated by tobit follows:

$$
\text { Growth }_{i j t+1}=\left\{\begin{array}{l}
X_{i j t}^{\prime} \beta+\mu_{i}+e_{i j t+1} \text { if } \text { Growth }_{i j t+1}^{*}>\widetilde{g}_{t+1} \\
-1 \text { if Growth } \text { Grjt+1 }^{*} \leq \widetilde{g}_{t+1}
\end{array}\right.
$$

where $X_{i j t}^{\prime}$ is the vector of regressors in growth equation (12). I estimate random effects tobit to control for firm unobserved heterogeneity, but the results are similar to pooled tobit.

Besides OLS with clusters, all methods assume homoscedasticity and no or equal correlation structure between firm level observations. To relax these assumptions, I re-estimate growth equation by GEE (generalized estimating equations), ignoring censoring, but allowing for flexible correlation structure and heteroscedasticity. While OLS with clusters provides correct standard errors, but inefficient estimates, GEE estimates are consistent, asymptotically normal and efficient if correlation structure is correctly specified. Also, until the mean is correctly specified the GEE estimates are robust to any mis-specification in the correlation structure. ${ }^{77}$

\section{Controlling for firm correlated unobserved heterogeneity}

In my data, Hausman test did reject the random effects model. Also, as Table 2.1. shows there are visible differences between the estimates of sales and solvency by fixed effects and all other models. These findings suggest that there is unobserved firm heterogeneity correlated with regressors. Since tobit and exit hazard rate models are non-linear, and one can expect that endogeneity problem will be repeated in exit equation as well, it is impossible to eliminate $\mu_{i}$ by differencing it out as in linear fixed effects model. Moreover, there is not a sufficient statistic for tobit/probit that would allow the unobserved effects to be conditioned out of maximum likelihood, so there is no "fixed effects tobit/probit" model.

Wooldridge (2002) suggests to use a Mundlak (1978) version of Chamberlain's assumption that unobserved heterogeneity can be modeled as a function of firm level means of included

\footnotetext{
${ }^{77}$ See Liang and Zeger (1986).
} 
regresors, so: $\mu_{i}=\overline{X_{i}} \xi+a_{i}$, where $\overline{X_{i}}$ is the vector of firm level means of individual regressors over the period a firm is observed and $a_{i}$ is that part of firm unobserved heterogeneity in the error term that is uncorrelated with $\overline{X_{i}}$ and $X_{i j t}^{\prime}$. Then $H 0: \xi=0$ is a test of no correlated heterogeneity. In my estimations I exclude the means of all dummies, industry-trend cross effects and variables $S T A T I C$ and $D 89$, since these are either not firm level variables or are firm specific, but not identifiable together with firm level means. ${ }^{78}$ However, I include the means of foreign employment share $(E S)$ and foreign growth rates $(F G)$ to allow for the possible correlation between foreign presence and firm unobserved heterogeneity. ${ }^{79}$ Including means as additional controls, I estimate the growth equation by the linear random effects, GEE and random effects tobit (where $a_{i} \sim N\left(0, \sigma_{a}^{2}\right)$ and $e_{i j t} \sim N\left(0, \sigma_{e}^{2}\right)$ ), but the coefficients are almost identical to pooled tobit estimates and the estimate of $\sigma_{a}^{2}$ is insignificant (see Table 2.2.). So I use pooled tobit for robustness checks later on, because it is less computationally demanding procedure. Intuitively, if adding firm level means solves the endogeneity problem then the previously observed differences between sales and solvency estimates by fixed and random effects estimator should disappear and Hausman test should not reject the random effects model with means, which is the case here.

\section{Estimation of firm exit and survival}

First, let me discuss few data issues that effect my survival/exit estimations. In my sample there are 273 exits, so for these firms I observe the complete duration spells. The other observations are right censored. In addition, by its nature the data are left truncated, i.e. there are firms that were founded and operated for several years before they enter my sample. So the time when I start to observe a firm is different from the time when it becomes under risk of exit. Using variable age $T$ as a measure of firm survival the time a firm becomes under risk of exit is the year 1989 or the year of firm incorporation if that appears later. Then if a firm enters my sample e.g. at age $T=6$, it is only because it did not exit before I observe it. If a firm exited I would not even know about it. Hence, the maximum likelihood function must account for the age $T$ at which a firm enters my sample to correct for this survivorship bias. I control for both right censoring and left truncation in my estimations.

In addition, due to "perfect failure determination" problem, I need to re-group annual and industry dummies into the bigger groups and exclude the industry-trend cross effects, otherwise the estimation procedures may not converge. The tabulation of exits across years demonstrates the problem of perfect failure determination by years:

Sample exits across years.

\begin{tabular}{|l||l|l|l|l|l|l|l|}
\hline year & 1994 & 1995 & 1996 & 1997 & 1998 & 1999 & 2000 \\
\hline Exit=0 & 1730 & 2492 & 3159 & 3710 & 4252 & 4739 & 4378 \\
\hline Exit=1 & 81 & 0 & 0 & 1 & 78 & 77 & 36 \\
\hline
\end{tabular}

\footnotetext{
${ }^{78}$ See Wooldridge (2002), pg. 487-489.

${ }^{79}$ E.g. a domestic firm might have a certain competitive advantage because it employs a very skillful manager. If the foreign firm hires this manager domestic firm looses its competitive advantage and firm unobserved heterogeneity should be negatively correlated with the mean of ES.
} 


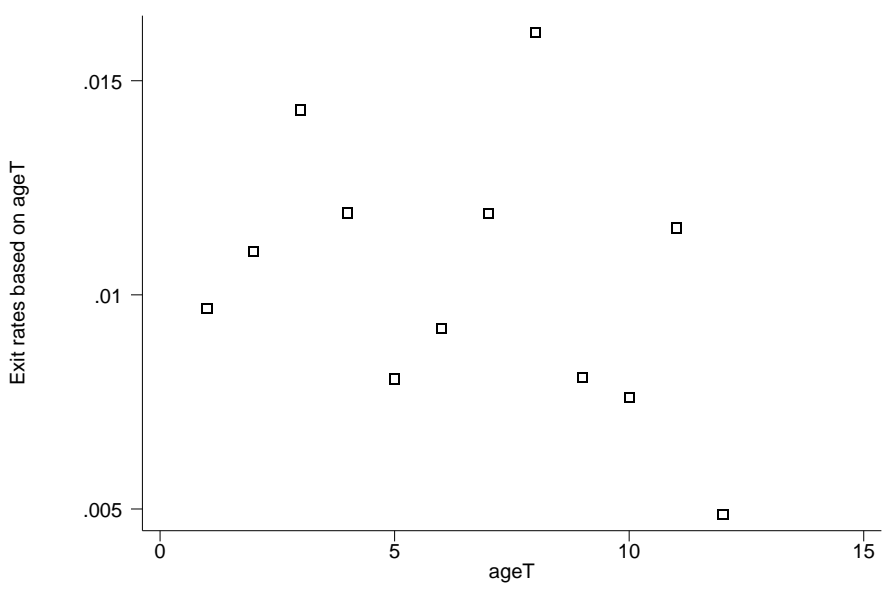

FIGURE 2: Exit rates for ageT

Since there are no exits in years 1995 and 1996, the coefficients of these year dummies would have to be $-\infty$. To avoid this problem, I create new year dummies, which merge the years $1994 \& 1995$ together and similarly years $1996 \& 1997$, so there is some variation in exit. ${ }^{80}$ Also, to control for industry demand then, I use the growth rate in industry sales (IndG) instead of industry-trend cross effects. ${ }^{81}$

I estimate firm exit by two types of methods. First I use survival analysis for continuous data because in reality firm survival is a continuos not a discrete/count variable (a firm can exit after 2.5 year). Specifically, I use a parametric Lognormal model and for robustness purposes non-parametric Cox model. However, since my data come from balance sheets that are reported annually, they are grouped by discrete intervals-years. Hence I also use discrete methods, namely probit/logit model. If the results are robust they should be similar across different specifications. More details about individual methods are below.

I use firm age $T$ as the measure of firm survival time $T$, which is modeled by a particular distribution (in notation below I denote the particular value of $T$ by $\widetilde{t}$ not to confuse it with year subscript $t$ ). Though the theoretical model implies decreasing hazard rates, assumed by Weibull distribution, Figure 2 indicates that my data rather exhibit non-monotonic hazard rates (the graph of exit rates based on firm age looks similar). ${ }^{82}$ Hence, I prefer Lognormal model that assumes non-monotone hazard rates. ${ }^{83}$ When I estimated the Weibull model the results

\footnotetext{
${ }^{80}$ Similarly, I re-group 29 industry dummies such that 3-digit industry without exits is merged with the adjacent 3 -digit industry that has some exits. In 8 cases I use 2-digit USSIC instead of 3-digit codes.

${ }^{81}$ Industry growth rate is calculated before data cleaning to get the most precise measure of the entire industry.

${ }^{82}$ Exit rates are calculated as the ratio: $\frac{d_{j}}{n_{j}}$, where $d_{j}=\#$ of firms which exited at ageT $=t_{j}$ and $n_{j}=\#$ of all firms at age $T=t_{j}$, which neither exited nor have been censored prior to $t_{j}$

${ }^{83}$ I also estimate log-logistic model, which also allows for non-monotone hazard rates. However, Lognormal model had higher maximum likelihood and thus lower Akaike information criterion (AIC), which is one way how to choose the proper distribution. $A I C=-2\left(\log _{-}\right.$likelihood $)+2(p+k)$, where $p$ is the number of ancillary parameters in the particular model and $k$ is the number of regressors including constant. Since $p$ and $k$ are the same in lognormal, log-logistic as well as Weibull model, the lowest AIC is determined by the highest value of log_likelihood.
} 
were similar to those from Lognormal and Cox, so the results are not sensitive to distributional assumptions, but Lognormal model have always a better fit. ${ }^{84}$

I first estimate the basic specifications without firm level means, assuming that firm unobserved heterogeneity is uncorrelated with regressors. Then, I estimate the specifications with firm level means to model firm correlated heterogeneity. The means again exclude all dummies, D89, and IndG (it does not vary across firms). In both specifications, I correct the standard errors for potential heteroscedasticity and arbitrary correlations within a firm by firm level clusters. (For the similar reasons as in case of OLS I also re-run the results specifying the industry-year clusters). I also estimate the frailty version of the Lognormal model that allows for observational unobserved firm heterogeneity, but most frailty specifications do not converge.

\section{Lognormal model}

Since lognormal hazard function is not monotonic it does not have the proportional hazard form as Cox model (or Weibull). The Lognormal model can be expressed only in "accelerated failure time" form given by equation:

$$
\begin{aligned}
\ln (T)= & \beta_{0}+\beta_{1} F G_{j t+1}+\beta_{2} \text { STATIC }+\beta_{3} \text { size }_{i j t}+\beta_{4} \text { size }_{i j t}^{2}+\beta_{5} E S_{j t}+\beta_{6} \text { FORdirect }_{i j}+ \\
& \beta_{7} \text { intang }_{i j t}+\beta_{8} \text { gap } \text { ijt }_{i j}+\beta_{9} \text { ESgap }_{i j t}+\beta_{10} \text { solvency }_{i j t}+\beta_{11} \text { IndG }_{j t+1}+\beta_{12} D 89+ \\
& \sum d_{t}+\sum d_{j}+\sum \text { region }+\omega_{i j t}
\end{aligned}
$$

where the error term $\omega_{i j t} \sim N\left(0, \sigma^{2}\right)$, and similarly as in growth equation I assume that $\omega_{i j t}=$ $\mu_{i}+e_{i j t}$, where $\mu_{i}$ is firm unobserved heterogeneity and $e_{i j t}$ is idiosyncratic error. Then density $f(\widetilde{t})$ of firm survival time $T$, and the probability that a firm survives up to time $\widetilde{t}, S(\widetilde{t})$ follow lognormal distribution, so: $f(\widetilde{t})=\frac{1}{\widetilde{t} \sigma \sqrt{2 \pi}} \exp \left[\frac{-1}{2 \sigma^{2}}\left(\ln (\widetilde{t})-X^{\prime} \beta\right)\right]$ and $S(\widetilde{t})=1-\Phi\left(\frac{\ln (\widetilde{t})-X^{\prime} \beta}{\sigma}\right)$ and the maximum likelihood function I estimate can be written as follows:

$$
\ln L=\sum_{i=1}^{N}\left\{d_{i} \ln \left[f\left(\widetilde{t_{i}} \mid X_{i} ; \beta\right)\right]+\left(1-d_{i}\right) \ln S\left(\widetilde{t_{i}} \mid X_{i} ; \beta\right)-\ln S\left({\widetilde{t_{i}}}^{\text {entry }} \mid X_{i} ; \beta\right)\right\} .
$$

$d_{i}=1$ if the observation is not censored and 0 if censored. $\widetilde{t}_{i}^{\text {entry }}$ is age $T$ at which a firm enters my sample, so the last term corrects for the left truncation in the data.

\section{Cox model}

The Cox proportional hazard model (Cox, 1972) specifies the firm exit hazard rate as follows: $h(\widetilde{t})=h_{0}(\widetilde{t}) e^{X^{\prime} \beta}$, where $h(\widetilde{t})$ is the rate at which firm exits given it survived up to time $\widetilde{t}, X^{\prime}$ is the same set of regressors as in equation (13) and the covariates represent the shifts in the baseline hazard $h_{0}(\widetilde{t})$. Then the exponentiated coefficient, $e^{\beta_{k}}$, represents the effect of a unit change in variable $X_{k}$ on hazard ratio. ${ }^{85}$ Due to this direct interpretation I report the exponentiated

\footnotetext{
${ }^{84}$ Weibull model also rejected the hypothesis of negative duration dependence. The estimated parameter in the baseline hazard was signficiantly greater than 1 , which suggests increasing hazard rates.

${ }^{85}$ Suppose that we have only one covariate $X_{k}$. Expressing the hazard ratio for two different values $X_{1 k}$ and $X_{2 k}$ where $X_{2 k}=X_{1 k}+1$ then for hazard ratio it holds that: $\frac{h\left(t, X_{2 k}\right)}{h\left(t, X_{1 k}\right)}=\frac{h_{0}(\widetilde{t}) e^{\left(X_{1 k}+1\right)^{\beta^{*}}}}{h_{0}(\widetilde{t}) e^{X_{1 k} \beta^{*}}}=e^{\beta^{*}}$.
} 
coefficients in my results. If the Cox results are logically consistent with those from Lognormal model, the same variables should be significant and the Cox coefficients should have the opposite signs. Unlike Lognormal model, Cox model does not assume any distribution, so it is a useful robustness check. If there are no exit ties (i.e. all firms exit at different time), the partial likelihood function for Cox model has the form:

$$
l=\prod_{i} \frac{h_{0}\left(\widetilde{t_{i}}\right) e^{X^{\prime} \beta}}{\sum_{j \in R\left(\widetilde{t_{i}}\right)} h_{0}\left(\widetilde{t_{i}}\right) e^{X^{\prime} \beta}}=\prod_{i}\left[\frac{e^{X_{i}^{\prime} \beta}}{\sum_{j \in R\left(\widetilde{t_{i}}\right)} e^{X_{j}^{\prime} \beta}}\right]
$$

where $\widetilde{t_{i}}$ is $i^{t h}$ exit time $(a g e T)$. The numerator is the hazard of the firm that exits at $\widetilde{t_{i}}$. The denominator is the sum of hazards for all firms in the risk set $R\left(\widetilde{t_{i}}\right)$, i.e. the firms that survive or

are censored at time $\widetilde{t_{i}}$, but which already entered my sample, so $\widetilde{t_{i}} \geq{\widetilde{t_{i}}}^{\text {entry }}$. However, in the case of the grouped data, as it is here, there are many ties because the data are reported annually. To handle tied exits I use Effron method, which is considered to be the best approximation (see Hosmer and Lemeshow (1999), pg.107, for the partial likelihood function adjusted for this approximation).

\section{Discrete regression analysis of hazard rates}

Including measure of survival time (ageT) among regressors as in growth equation, probit/logit model approximate the hazard rates. While the exponentiated logit coefficients give the prediction on proportional odds ratio, probit estimates give predictions on absolute probability of exit. The probit/logit equation I estimate is the same as the growth equation (12) but industry-trend cross effects are replaced by the industry growth rate and dependent variable is $\operatorname{Prob}\left(\right.$ Exit $\left._{i j t}=1\right)$ instead of Growt $_{i j t+1}$. Since logit results are similar I discuss only probit estimations.

In specifications that include firm level means to control for firm correlated heterogeneity, the vector of included means is the same as in survival analysis, so means of ageT, ageT2 and $A S$ are excluded. ${ }^{86}$ I use random effects probit specification to control for firm uncorrelated heterogeneity, but the results are similar to those from pooled probit with firm clusters, so only these are reported. ${ }^{87}$ Since probit model gives inconsistent estimates in case of heteroscedasticity as a specification test I estimate pooled probit with the usual standard errors and the pooled probit with standard errors corrected for heteroscedasticity, but no clusters (Evans (1987) uses the same approach). The standard errors are similar and provide the same statistical inference so I conclude that heteroscedasticity is not a problem here.

\footnotetext{
${ }^{86}$ I compare probit estimates with and without means of ageT variables by Hausman test to see whether these means may capture some additional "left out" correlation. Hausman test did not reject the specification without means of ageT at $1 \%$.

${ }^{87}$ Guilkey and Murphy (1993) argue that ignoring firm level heterogeneity in probit leads to severe bias in standard errors, but the probit estimator with firm level clusters performs almost as well as random effects probit.
} 


\section{Results}

\subsection{Results from estimation of firm growth}

The results without firm level means to control for correlated firm heterogeneity are reported in Table 2.1. and the results with means are in Table 2.2. I also separated the coefficients of primary interest, $(F G, S T A T I C)$, into those for classified domestic firms (cl), i.e. firms classified as domestic based on their ultimate ownership, and non-classified domestic firms (ncl), which have ownership information missing, but I treat them as domestic (see Data section). The tobit coefficients are always similar to those from other linear models and the marginal effects of regressors (evaluated at sample means) on unconditional mean growth rate, $(\partial g / \partial z)$, are close to the estimated tobit coefficients (see section 4.4.2). So I report the tobit coefficients rather than marginal effects. These similarities are probably due to low proportion of exits in my sample. ${ }^{88}$

The coefficients of the primary interest, $F G$ and $S T A T I C$, are very similar in both tables, inspite of the endogeneity problems due to correlated heterogeneity. ${ }^{89}$ The comparisons of the fixed effects estimates for sales and solvency (Table 2.1.) and the same coefficients obtained by all other methods in Table 2.2. confirm that including firm level means eliminates these differences. In addition, Hausman test in Table 2.2. does not reject linear random effect with means and the means are jointly significant all specifications.

In specifications with firm means (Table 2.2.) the coefficient of $F G$ is always positive and significant, which rejects the hypothesis of dynamic crowding out effect. Just the opposite, larger foreign growth rates seem to pull up growth rates of domestic firms. This result definitely holds for classified domestic firms, which seem to drive the pooled coefficient of $F G$, since the coefficient of $F G n c l$ is statistically insignificant. The coefficient $F G c l$ is very similar across all specifications from 0.0090 to 0.011 , and significant at $5 \%$. This implies that $1 \%$ increase in foreign industry growth rate increases the growth rate of a single domestic firm on average by cca. $0.01 \%$ or that the elasticity of domestic firm sales with respect to foreign industry sales is 0.01 . Also, the coefficient of $S T A T I C$, is negative but insignificant.

Both firm age and size have the expected negative effect and are always significant. The coefficient of $E S$, measuring intra-industry technology spillovers, has a positive sign, but is insignificant. Hence, if there are positive technology spillovers, they are small to affect domestic growth rates on average. In addition, the coefficient of FORdirect is 0.001 in most specifications, but it becomes insignificant after I control for unobserved heterogeneity which rejects the hypothesis of intra-firm technology spillovers. ${ }^{90}$ These results suggest that foreign investors target

\footnotetext{
${ }^{88}$ Similarly, the marginal effects on conditional mean $\left(g_{s}\right.$ in section 4.4 .2$)$ are similar to the estimated coefficients. However, tobit model imposes that the coefficients in selection and structural equations are the same. To verify whether relaxing this assumption might change the results I have estimated growth equation also by the Heckman procedure, which uses only surviving observations so it gives the predictions for conditional mean only. The estimated coefficients from growth equation were very similar to the coefficient from tobit.

${ }^{89}$ Interestingly, when I allow clusters on industry-year instead of firms in OLS, the standard errors of $F G$ variable decrease not increase. One reason is that the intra-cluster correlations are negative. Higher standard errors under firm clusters suggest that in my data it is more important to control for correlation of observations within a firm.

${ }^{90}$ Kinoshita(2000) also did not find technology spillovers from foreign partners when using the Czech data.
} 


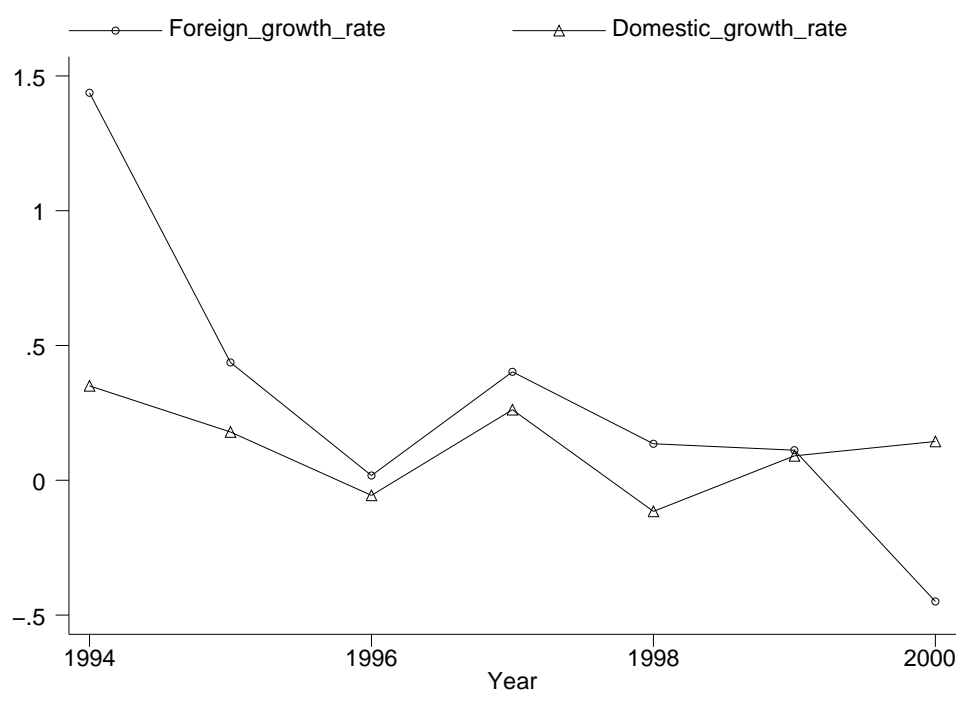

FIGURE 3: Average growth rates - domestic firms and foreign industry

the more productive firms with higher growth potential. ${ }^{91}$ Similarly, gap, intang and ESgap, are insignificant in most specifications. The coefficient of D89 dummy is negative and insignificant before I add firm level means to control for correlated heterogeneity. Then it becomes significant, which suggests that firms founded before 1989, have smaller growth rates despite of the fact that most of them might be receiving state subsidies. The solvency coefficient becomes insignificant after I add firm level means, which suggest that most domestic firms (not only previous SOE controlled by D89) do not face financial constraints. The switch in the coefficient is not surprising. The correlated heterogeneity most likely capture the unobserved user costs of capital. Due to this reason many studies in the finance literature use fixed effects estimator. ${ }^{92}$ I also find significant differences in growth performance across industries, but not across regions. This is not surprising, the $\mathrm{CR}$ is geographically very small, so regional developments are quite similar.

The results do not change even when I exclude the exit type dummies or re-estimate the growth equation including firm real age instead of ageT (these results are not reported to save space).This confirms that pre-transitional experience does not change the main results. The results also do not change when I include the dummy $\left(N O_{-} F O R=1\right)$ for industries/years without foreign presence. This dummy is insignificant (see the first 2 col. in Table 4.1) which shows that firms in industries without foreign presence do not have different growth rates.

No dynamic crowding out result is also suggested by the following figures. Figure 5 shows that the average growth rates in sales of the single domestic firms and average growth rates in sales of the foreign industry segment rather move together. Similarly, Figure 6 suggests that increasing foreign sales do not cause significant declines in the average sales of domestic firms.

\footnotetext{
${ }^{91}$ Aitken \& Harrison (1999) and Smarzynska Javorcik (2003) find similar effect.

${ }^{92}$ See e.g. Harrison and McMillan (2001)
} 


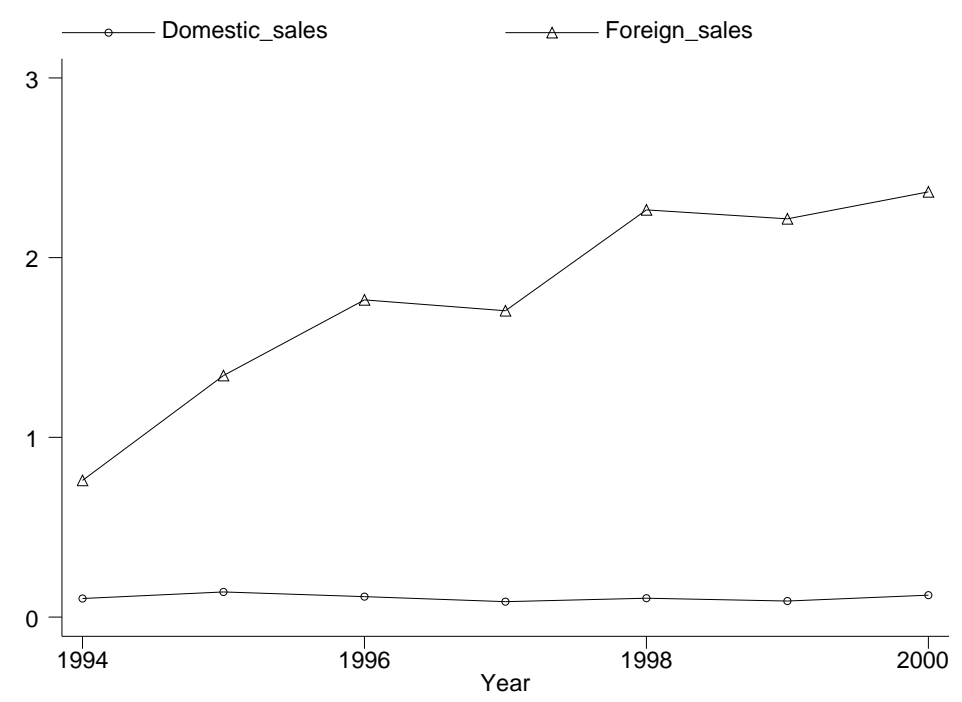

FIGURE 4: Average domestic and foreign industry sales

\subsection{Results from estimation of survival and exit}

The results from survival analysis are reported in Table 3.1 and the probit results are in Table 3.2. In Table 3.1. the exponentiated coefficients (standard errors calculated by delta method) are reported. In Cox model, the coefficients higher (smaller) than 1 increase (decrease) exit hazard ratio. Similarly, in Lognormal model the coefficients higher than 1 represent increase in firm mean survival time. The results show that endogeneity problem due to firm correlated heterogeneity has much serious impact on exit/survival than growth results. Without firm level means, only the coefficients of solvency, D89 and STATIC are significant across all models. When I control for the correlated heterogeneity via means the coefficient of $F G$ becomes significant at $1 \%$ in all specifications and other variables, sales, sales $2, E S$ become significant as well.

Though Cox model has much lower fit than Lognormal model, its results and logically consistent with those from Lognormal model. The coefficient of $F G$ (Table 3.1., col.9) implies that $100 \%$ increase in foreign growth rates increases firm mean survival time by $23 \%((1.233-1) 100 \%)$ or according to Cox model it reduces exit hazard rate by cca. 30\%. This finding holds for both classified and non-classified domestic firms. On the other hand, STATIC dummy has expected negative (positive) effect on firm survival (hazard rate), significant at $1 \%$ for both classified and nonclassified firms, but the impact seems to be larger for non-classifed firms. F test also rejects H0:FGcl = FGncl and H0:STATICcl = STATICncl, both at 5\% significance level. This suggests that there are some differences between these two groups, so in the robust specifications I focus on the estimations with separate coefficients.

These results reject the hypothesis of dynamic crowding out, but support the hypothesis of static crowding out effect. Moreover, dummy NO_FOR is significant in all specifications and implies that firms in industries without foreign presence have higher (lower) exit rates (survival 
time). These findings suggest that there is a shakeout of domestic firms upon foreign entry, but subsequently domestic firms benefit from growing foreign industry segment.

Regarding other results, larger sales and higher solvency reduce exit rates as expected. Also, Lognormal model suggests that firms founded before 1989 (D89) have higher mean survival time, so the state subsidies probably helped them to stay in business. The results also suggest positive intra-industry technology spillovers that help firms to survive. According to the coefficient of $E S$ in Lognormal model (col. 10) 100\% increase in foreign employment share increases mean survival time of domestic firms by more than $300 \%$. However, there is no evidence for intra-firm technology spillovers (FORdirect is insignificant). I also do not find any evidence of regional disparities, causing higher/lower exits rates, but there are significant industry differences.

Results from probit model with standard errors corrected for firm clusters are reported in Table 3.2.Though the probit model gives predictions on absolute probability of exit, while survival analysis gives prediction on hazard/time ratios, qualitatively the probit results confirm the previous findings from survival models. Expressing the marginal effects at sample means for probit coefficients in col. 6, the results imply that for classified firms 100\% increase in foreign growth rate decreases exit probability by $0.029 \%$ and for non-classified firms by $0.07 \%$. The results on static crowding out effect are also supported: the coefficient of STATIC dummy implies that foreign entry increases exit probability by $0.9 \%$ among classified and by $3.6 \%$ among nonclassified firms. Similarly, the marginal effect of $E S$ confirms positive technology spillovers - increasing the foreign employment share by $100 \%$ reduces exit probability for domestic firms by $0.3 \%$. In addition, positive and declining effect of ageT confirms the non-monotone hazard rates.

The results are similar across models when I use firm age instead of age $T$ or when I specify clusters on industry-year. The results are also similar when I use the sample for growth equation, which suggests that sales/growth observations are missing at random and systematic bias in exit results is unlikely. (These results is unreported to save space, but can be provided on request)

\subsection{Robustness checks}

Positive effect of foreign growth is a bit surprising, because if there is no dynamic crowding out I would expect no significant impact of foreign growth $(F G)$ on domestic firm growth rate and exit/survival. One explanation is that since it is impossible to include industry-year cross effects ( $F G$ would not be identifiable) there may be some time varying industry differences that are not fully captured by industry growth rate (in exit equation) or industry-trend cross effects (in growth equation). However, the alternative specifications below suggest that these results are quite robust across different sub-samples.

Another explanation is that $F G$ represents another type of spillovers, different from the technology spillovers that I measure by $E S$ ( $E S$ has proper sign and is significant in exit equation). Such spillovers can represent the export or domestic market creation through customer-supplier chains within 3-digit industries (vertical FDI spillovers). I will investigate these market creation possibilities more deeply in my dissertation. To verify whether the results differ across industries 
I estimate the growth and exit for these sub-samples:

I) \& II) Exclude industries without foreign presence. It is possible that results are driven by observations without foreign presence. So I exclude 11 industries without foreign presence during entire sample period (I). In addition, I exclude 4 industries (II) where foreign entry appears during my sample period. In these cases the foreign entry growth rates are set equal to 2 according to an alternative formula for growth rates, which may bias the results.

III) Only observations with positive foreign growth rates. There are cca. $37 \%$ of observations in growth sample (cca. $40 \%$ in exit sample) with $F G<0$. These probably document delayed filings and missing observations on sales, rather than declining foreign industry segment. However, if in these cases domestic firms are declining, this may cause positive correlation between FG and domestic growth rates and drive the overall results. Hence I restrict the sample only those observations where the foreign industry segment is truly expanding, i.e. where $F G>0$.

IV) Technology leaders vs. technology laggards. Blomström et al. (2000) suggest that crowding out effect might be specific to industries in which domestics firms are technologically less advanced than foreign firms. Thus I re-estimate the results for two groups: technology laggards and technology leaders. I define technology leaders as industries in which the mean of differences between intangible asset ratio of individual domestic firms and foreign intangible asset ratio, over the entire sample period, is greater or equal to zero. Analogically, technology laggards are the industries in which the same mean is less than zero. There are 83 industries defined as technology leaders and 47 industries defined as laggards (see Appendix, Table C4).

\subsubsection{Alternative specifications - domestic firm growth}

The results are in Table 4.1. and are estimated by pooled tobit with firm level means to control for correlated firm heterogeneity. The estimated coefficients from samples I)-III) are very similar to the estimated coefficients in aggregated sample (Table 2.2) and confirm the previous findings of foreign growth on domestic growth rates. For technology leaders, the coefficient of $F G$ is of similar magnitude as in aggregated sample (0.01) and significant at 10\%, but insignificant for technology laggards. These results still reject dynamic crowding out hypothesis. The results from these two samples bring interesting insights also on intra-industry spillovers. The coefficient of $E S$ is positive and significant at 5\%, suggesting that $1 \%$ increase in foreign employment share increases firm domestic growth rate by $0.3 \%$, but only for technology leaders. This supports the idea that in order to experience the growth enhancing technology spillovers a firm must have certain degree of technological advancement. Last, similarly as in aggregated sample there is no evidence of static crowding out effect or intra-firm technology spillovers on firm growth (ST ATIC and FORdirect are insignificant). 


\subsubsection{Alternative specifications - domestic firm exit}

The results from Lognormal and probit model including firm level means are reported in Table 4.2. ${ }^{93}$ They support previous findings of static but no dynamic crowding out effect. Across all subsamples, the coefficients of $F G$ show significantly positive (negative) effect of foreign growth on domestic firm mean survival time (probability of exit) and the coefficients of ST ATIC dummy show significantly negative (positive) effect of foreign entry on survival (exit). The Lognormal estimates imply that $100 \%$ increase in the foreign growth rate increases mean survival time by $15 \%-28 \%$ for classified domestic firms and more than $60 \%$ for non-classified firms. The probit results support these findings. Precisely, marginal effects (at sample means) imply that increasing FG by $100 \%$ reduces exit probability for classified firms by: $0.04 \%$ (sample I), $0.03 \%$ (II \& III), by $0.014 \%$ for technology leaders and by $0.1 \%$ for laggards. For non-classified firms these numbers are around three times larger. Lognormal estimates of ST ATIC dummy are similar as in Table 3.1 (col.9-10) and imply that foreign entry reduces mean survival time cca. by $74-80 \%$ for domestic classified firms and by $87-90 \%$ for non-classified firms across all sub-samples.

Similarly as in Table 3.1. there is also some evidence for the intra-industry technology spillovers, but no evidence of intra-firm spillovers (FORdirect is insignificant). The coefficient of ES increases mean survival time by more than $300 \%$ (the same magnitude as in aggregated results) in industries with foreign presence (samples I \& II) and from these for technology leaders. This is also confirmed by probit results. However, I do not find significant evidence of technology spillovers among technology laggards. On the other hand, the Logrank test rejects the hypothesis that the survival functions between these two groups are different.

\subsubsection{Do results depend on the degree of foreign ownership?}

I also re-estimate the growth and exit/survival equation for different sub-samples according to percentage of foreign direct ownership. The reason is that my findings of positive impact of foreign growth as well as positive technology spillovers on firm survival might be driven by the firms that are Czech based on ultimate ownership, but have some foreign shareholders. Aitken and Harrison (1999) also find that the positive gains from FDI are primarily captured by the joint ventures. Similar conclusions make Djankov and Hoekman (2000) using the Czech data. However, my results (not reported, but can be provided on request) reject this hypothesis. Just to the contrary, I find that main beneficiaries of stimulating effects from foreign growth as well as intra-industry technology spillovers are domestic firms with no foreign direct ownership. In addition, the finding of higher exit rates without foreign presence is also the strongest among these firms. The findings of static crowding out effect also do not change.

\footnotetext{
${ }^{93}$ Since each sub-sample contains smaller number of exits than aggregated sample again I re-group some industry dummies due to new perfect success determination problems.
} 


\section{Conclusion}

In this paper, I analyze the effect of foreign presence on growth and survival/exit of domestic firms. I distinguish the two opposing effects of foreign presence: a negative "crowding out" and a positive "technology spillover" effect. I focus on crowding out and address the question whether this effect is dynamic, where domestic firms continue to cut production over time as foreign firms grow in the domestic industry, or a static one realized upon foreign entry into the industry.

While previous studies analyzed FDI impact using production functions, I use a model, which combines a dominant firm-competitive fringe framework and a model on firm and industry dynamics by Jovanovic (1982) and Sun (2002). The model provides predictions for growth and exit/survival of domestic firms as a function of foreign industry growth rates, technology spillovers and other firm and industry characteristics. Specifically, it predicts that under dynamic crowding out effect foreign industry growth rate has negative impact on both growth rate and survival of domestic firms. If crowding out effect is a static one, however, we should observe negative relationship between domestic firm growth rate (survival) and the time of foreign entry into the industry. I test these predictions using 1994-2001 firm level panel data for the Czech Republic.

I estimate domestic firm growth equation by OLS with clusters, random and fixed effects, GEE and Tobit model. Firm survival/exit equations are estimated by Cox, Lognormal and discrete regression models. In all specifications I control for endogeneity problem due to firm level unobserved heterogeneity. My results show no evidence that foreign firms expand in the Czech markets at the expense of domestic firms or that foreign expansion induces excessive exit of domestic firms. In contrast, I find that foreign expansion, measured by the foreign sales growth rate, have a positive effect on both growth and survival of domestic firms. These results are robust across different empirical specifications. My findings are similar to the ones by DeBacker and Sleuwagen (2003) who conduct the industry level analysis and find that while FDI entry increases, the long run foreign presence decreases, exit rates in Belgium manufacturing industries. One explanation for my findings is that foreign growth rate represents export market creation or it captures vertical FDI spillovers due to backward and forward linkages among firms within the same 3-digit industry. I investigate this possibility in in my further work.

These results, together with significantly higher exit rates of domestic firms around the time of foreign entry, suggest that crowding out, and thus adjustment of domestic firms to FDI inflows, is just a one-time static effect realized upon foreign entry. So there is a shakeout of domestic firms when foreign firms enter, but subsequent to this initial entry effect, domestic firms benefit from expanding foreign industry. I also find that firms in industries without foreign presence have higher exit rates than firms in industries with foreign presence, even after controlling for industry effects and industry growth. This result suggests that foreign presence can improve the performance of domestic industries.

Using pooled sample across all industries I also find the evidence for intra-industry technology spillovers that help domestic firms to survive. However, the results across different sub-samples show that these spillovers have significant impact on firm growth rates only for technology leaders. 
On the other hand, there is no significant evidence for such technology spillover effect among technology laggards. This supports the hypothesis from the previous literature that in order to benefit from technology spillovers a domestic firm must have a certain level of technological advancement. In addition, the sub-sample analysis according to degree of foreign ownership rejects the possibility that my results are driven by foreign joint ventures.

From a policy perspective, my research suggests that indeed FDI does generate positive benefits for domestic firms, providing some justification for transitional countries granting preferential investment incentives to foreign firms.

\section{References}

Aitken, B. and Ann E. Harrison: "Do Domestic Firms Benefit from Direct Foreign Investment? Evidence from Venezuela", American Economic Review, Vol. 89 (3),1999, 605-617.

Audretsch, D. B.:" New-Firm Survival and the Technological Regime", Review of Economics and Statistics, Vol.73, 1991, 441-450.

Baltagi, H. Badi: "Econometric Analysis of Panel Data", John Wiley \& Sons Press, 1996.

Bilsen, V. and Jozef Konings: "Job Creation, Job Destruction and Growth of Newly Established, Privatized, and State-owned Enterprises in Transition Economies: Survey Evidence from Bulgaria, Hungary, and Romania", WDI WP, No. 106, November, 1997.

Blalock,G.: "Technology from Foreign Direct Investment: Strategic Transfer through Supply Chains", Dissertation 2002.

Blomström, M., Kokko, A. and Mario Zejan: "Foreign Direct Investment: Firm and Host Country Strategies", Macmillan Press LTD, 2000.

Blomström, M. and Fredrik Sjöholm: "Does Local Participation with Multinational Matter?", NBER WP 6816, November 1998.

Borensztein E., De Gregorio, J. and J-W. Lee: "How Does Foreign Direct Investment Affect Economic Growth?", Journal of International Economics, 45, 1998, 115-135.

Carlton, D. W. and Jeffrey M. Perloff: "Modern Industrial Organization", 3-rd edition, Addison-Wesley Longman, Inc., 2000.

Carpenter, R. E. and Bruce Petersen: "Is the Growth of Small Firms Constrained by Internal Finance?", The Review of Economics and Statistics, May 2002, 298-309.

Caves, R. E.:"Multinational Enterprises and Economic Analysis", Cambridge Surveys of Economic Literature, 2nd edition, Cambridge University Press, 1996.

Caves, R. E.: "Multinational Firms, Competition and Productivity in Host Country Markets", Economica, 41, 1974, 176-93.

Caves, R. E.: "Spillovers from Multinationals in Developing Countries: The Mechanisms at Work", WDI conference paper, June 1999.

Cohen, W. M. and D. A. Levinthal:"Absorptive Capacity: A New Perspective on Learning and Innovation", Administrative Science Quarterly, 35, 1990, 128-152. 
Chung, W.: "Downstream Foreign Direct Investment and U.S. Manufacturing Productivity", NYU Mimeo, 1999.

Chung, W., Mitchell, W. and Bernard Yeung: "Foreign Direct Investment and Host Country Productivity: The American Automotive Component Industry in the 1980s", NYU Mimeo, 1998.

Cordonnier, Ch. :"The Political Economy of FDI in Russia. What Prospects for European Firms?", European Business Club Report, 2002.

Cox, D. R.: "Regression Models and Life Tables (with discussion)", Journal of Royal Statistical Society: Series B, Vol. 34, 1972, pg. 187-220.

Cummins J.G.: "Taxation and the Sources of Growth Estimates from United States Multinational Corporations", NBER WP 6533, April 1998.

Das, S.: "Externalities, and Technology Transfer through Multinational Corporations", Journal of International Economics, 22, 1987, 171-182.

De Backer, K.: "Foreign Ownership and Firm Growth: Is Learning Transferable across Borders?", Working paper, Katholieke Universiteit Leuven, Leuven, Belgium. 2002.

De Backer, K. and Leo Sleuwaegen: "Does Foreign Direct Investment Crowd out Domestic Entrepreneurship?", Review of Industrial Organization, 22, 97-84, 2003.

Djankov, S. and Bernard Hoekman: "Foreign Investment and Productivity Growth in Czech Enterprises", World Bank Economic Review, Vol.14 (1), 2000, 49-64.

Dunne, T., Roberts, M. J. and Larry Samuelson: "The Growth and Failure of U.S. Manufacturing Plants", The Quarterly Journal of Economics, November 1989, 671-698.

Dunning, J. H. : "The Eclectic Paradigm of International Production: A Restatement and Some Possible Extensions", Journal of International Business Studies, Spring, 1988,1-31.

Dunning, J. H. and Alan M. Rugman: "The Influence of Hymer's Dissertation on the Theory of Foreign Direct Investment", American Economic Review, Vol. 75, 1985, 228-232.

Evans, D.: "Test of Alternative Theories of Firm Growth", Journal of Political Economy, Vol. 95 (4), 1987, 657-674.

Evans, D.: "The Relationship between Firm Growth, Size and Age: Estimates for 100 Manufacturing Industries", The Journal of Industrial Economics, Vol. XXXV, June 1987, 567-581.

Findlay, R. : "Relative Backwardness, Direct Foreign Investment, and the Transfer of Technology: A Simple Dynamic Model", Quarterly Journal of Economics, Vol. XCII (1), February ,1978, 1-16.

Foley, F.: "The Effect of Having an American Parent: An analysis of the Growth of U.S. Multinational Affiliates", Dissertation 2002.

Görg, H. and Eric Strobl: "Multinational Companies, Technology Spillovers and Firm Survival: Evidence from Irish Manufacturing", Centre for Research on Globalization and Labor Markets, School of Economics, University of Nottingham WP 12, 2000.

Guilkey, D.K. and J.L. Murphy: "Estimation and Testing in the Random Effects Probit Model", Journal of Econometrics, Vol. 59, 1993, pg. 310-317.

Gupta, N., Ham, J.C. and Jan Svejnar: "Priorities and Sequencing in Privatization: Theory and Evidence from the Czech Republic", WDI WP, September 2001. 
Haddad, M. and Ann Harrison: "Are There Positive Spillovers from Foreign Direct Investment? Evidence from Panel Data for Morocco", Journal of Development Economics, 42,1993, 51-74.

Hanson, G.: "Should countries promote FDI?", NBER WP prepared for G24 research program, September 2000.

Harrison, A. E. and Margaret S. McMillan: "Does Direct Foreign Investment Affect Domestic Firms Credit Constraints?", NBER WP , No. 8438, 2001. (forthcoming in Journal of International Economics 2003).

Haskel, J. E. , Pereira, S. C. and Matthew J. Slaughter: "Does Inward Foreign Direct Investment Boost Productivity of Domestic Firms?", NBER WP 8724, 2002.

Hooley, G., Cox, T., Shipley, D., Fahy, J., Beracs, J. and Krisztina Kolos: "FDI in Hungary: Resource Acquisition and Domestic Competitive Advantage", Journal of International Business Studies, Fourth Quarter, 1996, 683-709.

Hopenhayn, H. A.: "Entry, Exit and Firm Dynamics in Long Run Equilibrium", Econometrica, Vol. 60 (5), 1992, 1127-1150.

Hosmer, Jr. D. W. and Stanley Lemeshow: "Applied Survival Analaysis: Regression Modeling of Time to Event Data", John Wiley \& Sons, Inc., New York, 1999.

Hulten, Ch. R.: "Growth Accounting When Technical Change is Embodied in Capital", American Economic Review, Vol. 82 (4), September 1992, 964-980.

Hymer, S. and Peter Pashigian: "Firm Size and Rate of Growth", Journal of Political Economy, Vol. 52, 1962, 556-569.

ICEG (International Center for Economic Growth) European Center: "The Expected Effects of EU Accession on the Chemical Industries of the Visegrád Countries", Budapest, May 2003.

Jovanovic, B.: "Selection and the Evolution of Industry", Econometrica, Vol. 50(3),1982, 649-670.

Jovanovic, B. and Glenn M. MacDonald: "Competitive Diffusion", Journal of Political Economy, Vol. 102 (1), 1992, 24-52.

Jovanovic, B. and Glenn M. MacDonald: "The Life Cycle of a Competitive Industry", Journal of Political Economy, Vol. 102 (2), 1992, 322-34\%.

Kaplan, N. S. and Luigi Zingales: "Do Investment-Cash Flow Sensitivities Provide Useful Measures of Financing Constraints?", Quarterly Journal of Economics, Feb. 1997, 169-215.

Kinoshita, Y.: "R\&D and Technology Spillovers via FDI: Innovation and Absorptive Capacity", CERGE-EI, CEPR and WDI WP, November 2000.

Kocenda, E. and Jan Svejnar: "Ownership and Firm Performance after Large-Scale Privatization", William Davidson Institute WP, 2003.

Konings, J. : "The effect of FDI on Domestic Firms: Evidence from Firm Panel Data in Emerging Economies", CEPR Working Paper, 1999.

Kumar,N.: "Mode of Rivalry and Comparative Behavior of Multinational and Local Enterprises: The Case of Indian Manufacturing", Journal of Development Economics,35, 1991, 381-392. 
Levinsohn, J. and Amil Petrin: "Estimating Production Functions Using Inputs to Control for Unobservables", NBER ,WP \#7819, 2000.

Liang Kung-Yee and Scott L. Zeger: "Longitudinal Data Analysis Using Generalized Linear Models", Biometrika, Vol. 73 (1), 1986, 13-22.

Lízal, L. and Jan Svejnar: "Investment, Credit Rationing and the Soft Budget Constraint: Evidence from Czech Panel Data", The Review of Economics and Statistics, 84 (2), 2002, 353-370.

Mansfield E. : "Entry, Gibrat's Law, Innovation, and the Growth of Firms", American Economic Review, Vol.52, 1962,1023-1051.

Markusen, J.R.: " The Boundaries of Multinational Enterprises and the Theory of International Trade", Journal of Economic Perspectives, Vol. 9 (2), 1995,169-189.

Moulton, B.: "An Illustration of Pitfalls in Estimating the Effects of Aggregate Variables on Micro Units", The Review of Economics and Statistics, Vol. 72, 1990, 334-338.

Mowery, D. C., Oxley, J. E. and Brian Silverman: "Strategies Alliances and Interfirm Knowledge Transfer", Strategic Management Journal, Vol. 17 (Winter Special Issue), 1996, 77-91.

Mundlak,Y. : "On the Pooling of Time Series and Cross Section Data", Econometrica, Vol. 46, (1), January, 1978, 69-85.

Olley, G. S. and Ariel Pakes: "The Dynamics of Productivity in the Telecommunications Equipment Industry", Econometrica, Vol. 64 (6), 1996, 1263-1297.

Oxley, J. : Appropriability Hazards and Governance in Strategic Alliances: A Transaction Costs Theory Approach", Journal of Law, Economics and Organization,13 (2), 1997, 387-409.

Pakes, A. and Richard Ericson: "Empirical Implications of Alternative Models of Firm Dynamics", Journal of Economic Theory, 79, 1998, 1-45.

Rodriguez-Clare A.: "Multinationals, Linkages and Economic Development", American Economic Review, Vol. 86 (4),1996, 852-873.

Sjöholm, F: "Technology Gap, Competition and Spillovers from Direct Foreign Investment: Evidence from Establishment Data", Journal of Development Studies, Vol.36 (1), 1999, 53-73.

Smarzynska Javorcik, B. : "Does Foreign Direct Investment Increase the Productivity of Domestic Firms? In Search of Spillovers through Backward Linkages", World Bank WP, July, 2003.

Smarzynska Javorcik, B. and Mariana Spatareanu: "To Share or Not To Share: Does Local Participation Mater for Spillovers from Foreign Direct Investment?", World Bank WP, July, 2003.

Stigler, G.: "The Dominant Firm and the Inverted Umbrella", Journal of Law and Economics, Vol. 8., 1965. Reprinted as Chapter 9 in G. Stigler, The Organization of Industry. Homewood, IL:Richard D. Irwin, pg. 108-22.

Sun, S.: "Is Firm Growth Proportional of Disproportional? A Reconciliation with an Application Using Franchising Data", Unpublished dissertation, Department of Economics, University of Michigan, Ann Arbor, MI, 2002.

Sutton, J.: "Gibrat's Legacy", Journal of Economic Literature, Vol.XXXV, 1997, 40-59.

Svejnar, J.: "Transitional Economies: Performance and Challenges", Journal of Economic Perspectives, Vol. 16 (1),Winter, 2002, 2-28. 
Wang, J. and Magnus Blomström: "Foreign Investment and Technology Transfer: A Simple Model", European Economic Review, 36, 1992, 137-155.

Wooldridge, J. M.: "Econometric Analysis of Cross Section and Panel Data", MIT Press, 2000.

\section{Appendix A: Theory}

A1: Discrete growth rate of competitive fringe firm.

Expressing the FOC at time $t$ and $t+1$ and taking the ratio, we get: $\frac{p_{t+1}}{p_{t}}=\frac{C^{\prime}\left(q_{t+1}^{*}\right)}{C^{\prime}\left(q_{t}^{*}\right)} \frac{T_{t+1}}{T_{t}} \frac{x_{t+1}^{e}}{x_{t}^{e}}$, which in logarithmic transformation gives:

$$
\log \frac{p_{t+1}}{p_{t}}=\log \frac{C^{\prime}\left(q_{t+1}^{*}\right)}{C^{\prime}\left(q_{t}^{*}\right)}+\log \frac{x_{t+1}^{e}}{x_{t}^{e}}+\log \frac{T_{t+1}}{T_{t}} .
$$

Using continuous time approximation for change in costs and the assumption $\frac{C^{\prime}}{q C^{\prime \prime}}=k$ we get: $\log \frac{C^{\prime}\left(q_{t+1}^{*}\right)}{C^{\prime}\left(q_{t}^{*}\right)} \approx \frac{d C^{\prime}\left(q_{t}^{*}\right)}{C^{\prime}\left(q_{t}^{*}\right)}=\frac{C^{\prime \prime}\left(q_{t}^{*}\right) d q_{t}^{*}}{C^{\prime}\left(q_{t}^{*}\right)} \frac{q_{t}^{*}}{q_{t}^{*}}=\frac{1}{k} \frac{d q_{t}^{*}}{q_{t}^{*}} \simeq \frac{1}{k} \log \frac{q_{t+1}^{*}}{q_{t}^{*}}$. Since $\log \frac{z_{t+1}}{z_{t}} \simeq \frac{z_{t+1}-z_{t}}{z_{t}}$ we can express a firm's discrete growth rate as: $\frac{q_{t+1}^{*}-q_{t}^{*}}{q_{t}^{*}}=k\left(\frac{p_{t+1}-p_{t}}{p_{t}}-\frac{x_{t+1}^{e}-x_{t}^{e}}{x_{t}^{e}}-\frac{T_{t+1}-T_{t}}{T_{t}}\right)$. Substituting for $T_{t+1}=$ $T_{t}\left(1-u_{t+1}\right)$ gives equation $(2): \frac{q_{t+1}^{*}-q_{t}^{*}}{q_{t}^{*}}=k\left(\frac{p_{t+1}-p_{t}}{p_{t}}-\frac{x_{t+1}^{e}-x_{t}^{e}}{x_{t}^{e}}+u_{t+1}\right)$.

\section{A2: Domestic firm exit decision.}

Following Jovanovic (1982) if a firm decides to exit at any period it obtains a scrap value $W>0$ (constant across firms and time). Let be $x_{t}^{e}=x$ at time $t$. Then the firm' s perceived value of staying in the industry at period $t$ given a price sequence $p$ is (see also Sun (2002)):

$$
\begin{aligned}
V\left(x, n, t, T_{t} ; p\right)=\max _{q_{t}} & {\left[p_{t} q_{t}-C\left(q_{t}\right) T_{t} x\right]+} \\
& +\rho \iint \max \left\{V\left(z, n+1, t+1, T_{t}\left(1-u_{t+1}\right) ; p\right), W\right\} d P(z \mid x, n) d F\left(u_{t+1}\right)
\end{aligned}
$$

where $\rho$ is a discount factor. Since $T_{t+1}=T_{t}\left(1-u_{t+1}\right)$ and the shock $u_{t+1}$ is i.i.d, so it is independent of $T_{t+1}$ and $x_{t+1}^{e}$, the expected value of future profits can be obtained as the product of two marginal distributions, where $P(z \mid x, n)$ is the posterior distribution of $x_{t+1}^{e}$ (the probability that $x_{t+1}^{e} \leq z$ given that $x_{t}^{e}=x$ and that a firm has been in the industry for $n$ periods), and $F\left(u_{t+1}\right)$ is the c.d.f of distribution $N\left(\bar{u}, \sigma_{u}^{2}\right)$. It can be shown that a unique, bounded and continuous solution for $V$ exists and that $V$ is strictly decreasing in $x$ (Jovanovic, pg. 666). This also uniquely determines the firm's exit threshold $\overline{x_{t}}\left(n, t, T_{t} ; p\right)$, i.e. such value of $x_{t}^{e}$ that solves $V\left(x, n, t, T_{t} ; p\right)=W$. If $x_{t}^{e}>\overline{x_{t}}$ firm's efficiency is too low and a firm exits at time $t$. Since $q_{t}$ is decreasing in $x_{t}^{e}$ (with constant $k, q_{t}$ is convex in $x_{t}^{e}$ ) exit threshold $\overline{x_{t}}$ then determines the exit output level, $\overline{q_{t}}\left(p_{t}, T_{t}, \overline{x_{t}}\right)$.

\section{A3: Competitive fringe supply.}

Following Jovanovic (1982, part 4.) let $q_{t}\left(p_{t}, T_{t}, x\right)$ be the level of output that maximizes firm 
profits at time $t$ when $x_{t}^{e}=x$. Then let

$$
\begin{aligned}
& \Psi\left(x \mid t, T_{t}, \tau ; p\right)=\operatorname{Pr}\left[x_{s}^{e}<\bar{x}\left(s-\tau, s, T_{s} ; p\right), s=\tau+1, \ldots, t-1\right. \\
& \quad \text { and } x_{t}^{e}<\min \left[x, \bar{x}\left(t-\tau, t, T_{t} ; p\right)\right] \text { given } x_{\tau}^{e}=x_{0} \\
& \text { and that entry occurred at } \tau(\tau<t)] ;
\end{aligned}
$$

be the probability that a firm which enters at time $\tau$ is still in the industry at time $t$, at which its $x_{t}^{e} \leq x$. Also let $F\left(T_{t} \mid t, \tau\right)$ be the distribution of $T_{t}$. Then the expected output at time $t$ of a firm of vintage $\tau$ is: $\phi(t, \tau ; p) \equiv \iint q_{t}\left(p_{t}, T_{t}, x\right) d \Psi\left(x \mid t, T_{t}, \tau ; p\right) d F\left(T_{t} \mid t, \tau\right)$.

If $y_{\tau}$ is the measure of entrants at time $\tau$, the output of these firms at $t$ is $y_{\tau} \phi(t, \tau ; p)$. Since each firm is of measure zero, this output is deterministic. So even if there is a firm level uncertainty there is no aggregate uncertainty and the total supply of FC at time $t$ is:

$$
Q_{t}^{C F}=\sum_{\tau=0}^{t} y_{\tau} \phi(t, \tau ; p) \equiv Q_{t}^{C F}(p, y)
$$

where $p=\left\{p_{\tau}\right\}_{0}^{\infty}$ is a price sequence and $y \equiv\left\{y_{\tau}\right\}_{0}^{\infty}$ is an entry sequence. So $Q_{t}^{C F}(p, y)$ is total output of $\mathrm{CF}$ at $t$ given an arbitrary pair of entry and price sequences and if they make optimal output and exit decisions in response to the price sequence $p$ (see Jovanovic,pg. 657). Since the

price sequence determines the entry decision we can rewrite $Q_{t}^{C F}(p, y) \equiv Q_{t}^{C F}(p)$. Given the equilibrium price sequence $p$, the equilibrium entry sequence then satisfies:

$$
\begin{aligned}
& V\left(x_{0}, 0, t ; p\right)-K=W \text { if } y_{t}>0 \\
& V\left(x_{0}, 0, t ; p\right)-K \leq W \text { if } y_{t}=0
\end{aligned}
$$

where $K>0$ is one time entry costs, and $W>0$ is the scrap value upon exit.(see part A2 above). Thus at each $t$ the net present value of entry can not be positive, otherwise more firms would enter so it would not be an equilibrium.

\section{Appendix B: Data procedures}

\section{B1: Balance sheet cleaning and filling in procedures.}

Using pre-cleaned sample of 10157 firms (66080 obs.) I did the following cleaning steps. First, for several firms region was missing but city was reported. So using firm name and city I found the regions using the Czech firm search engine "SEZNAM" and the geographic search of the Czech regional office ("Informační systém o území"). Second, I deleted the observations with coding mistakes in the balance sheets, precisely: if total assets, intangible assets, sales, fixed assets, number of employees, costs of employees were negative (263 obs.), or if the sum of balance sheet items entering total assets was $20 \%$ higher or lower than the reported total assets (40 obs.) and similarly for liabilities (87 obs. deleted). Third, if sales, employment, intangible assets, total 
assets and solvency rate was missing for a year between two non-missing values, I filled in the missing observations with the mean of the two non-missing observ. (If more than 2 consecutive observations were missing such observation was dropped from the regression analyses). Finally, I excluded 4252 outlier observations. ${ }^{94}$

\section{B2: 11 industries (3-digit USSIC) without foreign presence:}

172 (painting and paper hanging), 175 (carpentry and floor work), 252 (office furniture manuf.), 332 (iron and steel foundries), 347 (coating engraving and allied services), 351(engines and turbines), 375 (motorcycles, bicycles and parts manuf.), 391 (jewelry, silverware and plated ware), 628 (services allied with the exchange of securities and commodities), 672 (investment offices), 792 (theatrical producers, bands, orchestras and entertainers).

\section{B3: Identification of exits in Business Registrar.}

To verify whether a firm is still active or it entered the liquidation/bankruptcy process the firm records were individually checked (by firm identification numbers) in the Business Registrar at the Czech Dept. of Justice. ${ }^{95}$ I took as the pool of potential exitors all firms that filed their last balance sheet into the Amadeus database before 2001 (the end of my sample).

Number of last balance sheets filed to Amadeus across years.

\begin{tabular}{|l||l|l|l|l|l|l|l|}
\hline year of last BS filed & 1996 & 1997 & 1998 & 1999 & 2000 & 2001 & total \\
\hline no. of firms & 725 & 840 & 867 & 967 & 3435 & 2723 & 9560 \\
\hline
\end{tabular}

As the table shows there is quite high number of last balance sheets filed in 2000 and $2001 .^{96}$ Since these most likely represent the filing delays, I took as my pool of potential exitors those firms that filed the last balance sheet in or before 1999 (3399 firms). I checked them individually in the Business Registrar and collected information as to whether the firm is still active, in liquidation/bankruptcy, in both processes, or is already out of the registrar. If a firm was out by the time I collected this data (February 2003), it must have already been liquidated and deleted from the registrar. In such cases the start of liquidation is unknown, so I take the year of the last reported sales as the exit year (191 firms) and the year of the last balance sheet reported if sales are missing (146 firms). ${ }^{97}$ I added among true exits other 100 firms that filed their last

\footnotetext{
${ }^{94}$ Outlier observations are those with:growth rates $>500 \%$ (744 observ.), firms with intangible asset ratio or solvency ratio equal to 1 , which does not change over the entire firm time series (253 obs.), observ. with outlying values of $\mathrm{K} / \mathrm{L}$ ratio and industries with foreign or industry growth rates $>200000 \%$ (29 obs.). Moreover, observations were deleted if foreign industry market shares were equal to 1 but there exist domestic firms with missing sales (77 obs.). Similarly, the observations with foreign industry market shares equal to 0 were deleted, if foreign companies were present, but their sales values were missing (3149 observ.).

${ }^{95}$ According to the Czech corporate law and the Law for the Statistical Office every firm can have only one identification number even if it performs many activities. This number must be recorded in the Business Registrar. When a firm exits the market, its number is deleted from the Business Registrar and can never be assigned again.

${ }^{96}$ In addition, there were 597 firms that did not have any balance sheet information - only the company name and address were provided.(597 +9560 firms above $=10157$ firms in pre-cleaned data).

${ }^{97}$ The year of the last reported sales matched the year of the last reported balance sheet for 191 firms at $96 \%$. I use the year of the last reported sales, because among the firms which were in the registrar I found 11 cases with the last balance sheets reported after the official start of bankruptcy/liquidation (B/L) process, but only 3 firms that reported positive sales after the official start of B/L.
} 
balance sheets after 1999, but had in their company name a statement "v likvidaci", i.e. "in liquidation". By the Czech corporate law a firm must add this statement to its name when it enters the liquidation process. In the end there are 1143 exits in my pre-cleaned data, 398 of which are firms in bankruptcy, 168 in liquidation, 259 in both (bankruptcy and liquidation) and 337 firms are out of the Business Registrar.

\section{B4: Determination of ultimate ownership.}

The Amadeus database assigns an ultimate owner for a firm that has at least one shareholder with a stake $\geq 24.9 \%$ and the firm does not report an ultimate owner by itself. (In my sample of 10335 firms 2352 firms had also the country of ultimate owner provided, so the classification Czech vs. foreign was straightforward). If a firm does not have a single majority shareholder with a stake $\geq 24.9 \%$ Amadeus does not assign an ultimate owner to a firm. For these firms I classify a firm as foreign if the average of sums of foreign direct ownership across firm time series is greater than 50\% (20 firms are defined as foreign in this way). Analogically, if this average is less than $50 \%$ I classify a firm as domestic. However, for many firms with ultimate owner assigned, the country of ultimate owner was missing, but the ultimate owner name was reported. For these (1705) firms I develop special cleaning procedures that use the name of an ultimate owner and search it for the country initials, the abbreviations of foreign legal forms etc. that would imply that an ultimate owner is not Czech. Finally, I classify as foreign also those firms that have ultimate owner missing or "unknown", even if the majority shareholder exists, but that have the average (across firm time series) of a sum of foreign direct ownerships $\geq 60 \%$ (I use $60 \%$ threshold to exclude the possibility that there exist an "unknown" majority shareholder with a stake of 50\%). At the end out of 10335 firms: 5344 are classified as domestic, 1412 as foreign and 3578 firms are non-classified. 
Table 1.1.: Foreign Direct Investment in CEEC's Countries: 1989-2003

A. Net Inflows, in Millions of US Dollars

\begin{tabular}{|c|c|c|c|c|c|c|c|c|c|c|c|c|c|c|c|c|}
\hline & 1989 & 1990 & 1991 & 1992 & 1993 & 1994 & 1995 & 1996 & 1997 & 1998 & 1999 & 2000 & 2001 & 2002 & $2003^{*}$ & $\begin{array}{r}\text { Cumulative } \\
1989-2004\end{array}$ \\
\hline Czech Rep. & 257 & 132 & 513 & 983 & 563 & 749 & 2,526 & 1,276 & 1,275 & 3,591 & 6,234 & 4,943 & 4,820 & 8,226 & 5,000 & 40,831 \\
\hline Croatia & 0 & 0 & 0 & 13 & 102 & 110 & 109 & 486 & 347 & 835 & 1,445 & 1,086 & 1,424 & 1,000 & 673 & 7,630 \\
\hline Hungary & 0 & 311 & 1,459 & 1,471 & 2,328 & 1,097 & 4,410 & 2,279 & 1,741 & 1,555 & 1,720 & 1,123 & 2,255 & 598 & 1,288 & 23,635 \\
\hline Poland & 11 & 0 & 117 & 284 & 580 & 542 & 1,134 & 2,741 & 3,041 & 4,966 & 6,348 & 8,171 & 6,928 & 3,700 & 6,000 & 44,552 \\
\hline Slovak Rep. & 0 & 24 & 82 & 100 & 107 & 236 & 194 & 199 & 84 & 374 & 701 & 2,058 & 1,460 & 4,007 & 2,000 & 11,626 \\
\hline Slovenia & n.a. & -2 & -41 & 113 & 111 & 129 & 161 & 167 & 303 & 221 & 59 & 71 & 371 & 1,790 & 230 & 3,683 \\
\hline Estonia & n.a. & na & na & 80 & 156 & 212 & 199 & 111 & 130 & 574 & 222 & 324 & 343 & 185 & 200 & 2,736 \\
\hline Latvia & n.a. & na & na & 29 & 50 & 279 & 245 & 379 & 515 & 303 & 331 & 400 & 151 & 388 & 350 & 3,420 \\
\hline Lithuania & n.a. & na & na & 8 & 30 & 31 & 72 & 152 & 328 & 921 & 478 & 375 & 439 & 714 & 550 & 4,098 \\
\hline Bulgaria & 0 & 4 & 56 & 41 & 40 & 105 & 98 & 138 & 507 & 537 & 789 & 1,003 & 641 & 430 & 900 & 5,289 \\
\hline Romania & 0 & -18 & 37 & 73 & 87 & 341 & 417 & 415 & 1,267 & 2,079 & 1,025 & 1,051 & 1,154 & 1,080 & 1,100 & 10,108 \\
\hline$E$ & 42,282 & 58,480 & 48,053 & 54,595 & 49,034 & 47,082 & 68,814 & 70,696 & 75,204 & 145,563 & 206,428 & 401,868 & n.a. & n.a. & n.a. & $1,225,816$ \\
\hline
\end{tabular}

${ }^{*}$ Estimate,

Source: WDI data-tables, based on EBRD Transition Report May 2003 and World Bank World Development Indicators 2002

B. Per Capita Net Inflows, US Dollars

\begin{tabular}{lrrrrrrrrrrrrrrr}
\hline & $\mathbf{1 9 8 9}$ & $\mathbf{1 9 9 0}$ & $\mathbf{1 9 9 1}$ & $\mathbf{1 9 9 2}$ & $\mathbf{1 9 9 3}$ & $\mathbf{1 9 9 4}$ & $\mathbf{1 9 9 5}$ & $\mathbf{1 9 9 6}$ & $\mathbf{1 9 9 7}$ & $\mathbf{1 9 9 8}$ & $\mathbf{1 9 9 9}$ & $\mathbf{2 0 0 0}$ & $\mathbf{2 0 0 1}$ & $\mathbf{2 0 0 2}$ & $\mathbf{2 0 0 3}$ \\
\hline Czech Rep. & 24.86 & 12.74 & 49.76 & 95.25 & 54.50 & 72.44 & 244.53 & 123.64 & 123.79 & 348.98 & 606.42 & 481.30 & 469.54 & 802.06 & 487.07 \\
Croatia & 0.00 & 0.00 & 0.00 & 2.72 & 21.35 & 23.03 & 23.52 & 107.39 & 78.04 & 189.92 & 330.32 & 247.95 & 314.19 & 221.43 & 148.49 \\
Hungary & 0.00 & 29.99 & 140.97 & 142.54 & 226.24 & 106.92 & 431.09 & 223.65 & 171.53 & 153.81 & 170.80 & 112.08 & 224.48 & 59.64 & 128.22 \\
Poland & 0.29 & 0.00 & 3.06 & 7.40 & 15.08 & 14.06 & 29.39 & 70.97 & 78.68 & 128.42 & 164.24 & 211.41 & 179.04 & 95.57 & 155.06 \\
Slovak Rep. & 0.00 & 4.55 & 15.53 & 18.83 & 20.11 & 44.11 & 36.19 & 37.06 & 15.61 & 69.39 & 129.81 & 381.11 & 269.93 & 739.99 & 369.76 \\
Slovenia & n.a. & -1.00 & -20.50 & 56.50 & 56.35 & 64.82 & 80.90 & 83.92 & 152.26 & 111.62 & 29.65 & 35.68 & 189.14 & 915.75 & 117.25 \\
\hline Estonia & n.a. & n.a. & n.a. & 51.95 & 102.63 & 141.33 & 134.46 & 76.55 & 90.91 & 407.09 & 159.71 & 236.50 & 240.74 & 130.61 & 140.37 \\
Latvia & n.a. & n.a. & n.a. & 11.03 & 19.31 & 109.41 & 97.22 & 152.21 & 208.50 & 123.67 & 137.34 & 168.78 & 63.14 & 163.55 & 146.34 \\
Lithuania & n.a. & n.a. & n.a. & 2.14 & 8.04 & 8.33 & 19.35 & 40.97 & 88.41 & 248.92 & 129.19 & 101.35 & 118.67 & 193.04 & 148.68 \\
Bulgaria & 0.00 & 0.46 & 6.49 & 4.80 & 4.72 & 12.44 & 11.67 & 16.51 & 61.01 & 65.01 & 96.10 & 122.77 & 78.46 & 52.63 & 110.16 \\
Romania & 0.00 & -0.78 & 1.60 & 3.20 & 3.82 & 15.00 & 18.39 & 18.35 & 56.19 & 92.40 & 45.64 & 46.84 & 51.43 & 48.13 & 49.02 \\
\hline EU & 145.33 & 160.41 & 131.23 & 148.40 & 132.70 & 126.99 & 185.12 & 189.63 & 201.19 & 388.62 & 549.82 & $1,067.67$ & n.a. & n.a. & n.a. \\
Source: WDI Staff calculations based on the World Bank World Development Indicators 2002 and EBRD Transition Report May 2003.
\end{tabular}


Table 1.2. : Performance Comparison - domestic vs. foreign firms, 1994-2001. 142 industries with at least 10 domestic firms, including those without foreign presence.

Results of treatment regression: $y=$ const $+b^{*}(F O R=1)$

\begin{tabular}{|l|c|c|c|c|}
\hline & mean & difference in means & No. of observations \\
\cline { 3 - 5 } Variable & domestic & foreign-domestic & domestic foreign \\
\hline growth rate & (const) & $($ FOR=1) & & \\
market share & $0.087^{* *}$ & $0.097^{* *}$ & 21007 & 4425 \\
market share (US2) & $0.027^{* *}$ & $0.021^{* *}$ & 26954 & 5606 \\
employment & $0.007^{* *}$ & $0.009^{* *}$ & 26954 & 5606 \\
operating revenue & $224^{* *}$ & $142^{* *}$ & 26137 & 5340 \\
K/L & $10773^{* *}$ & $14366^{* *}$ & 26917 & 5581 \\
intangible assets & $108^{* *}$ & $30^{* *}$ & 25934 & 5282 \\
total assets & $86^{*}$ & $198^{*}$ & 27668 & 5747 \\
intangible ratio & $12482^{* *}$ & $14364^{* *}$ & 27750 & 5754 \\
sales & $0.008^{* *}$ & -0.0001 & 27668 & 5747 \\
value added & $0.1^{* *}$ & $0.141^{* *}$ & 26954 & 5606 \\
return on assets & $3822^{* *}$ & $13008^{* *}$ & 25748 & 5392 \\
liquidity ratio & $1.57^{* *}$ & $1.03^{* *}$ & 27251 & 5650 \\
solvency ratio & $1.94^{* *}$ & -0.005 & 27415 & 5672 \\
cashflow ratio & $0.393^{* *}$ & -0.024 & 27750 & 5754 \\
profit margin & $0.051^{* *}$ & $0.02^{*}$ & 26953 & 5617 \\
\hline$*$ & 0.076 & $0.414^{* *}$ & 26154 & 5430 \\
\hline
\end{tabular}

** significant at 5\%, * significant at $10 \%$

Notes:

Domestic firms include both classified domestic and non-classified firms.

("non-classified" firms are those without ultimate ownership information treated as domestic) Comparison between foreign and "classified" domestic firms (firms classified as domestic according to non-missing ultimate ownership) gave the same results.

NOTICE: on average the domestic firms are working on the 0 profit margin

\section{Variables are:}

growth rate=growth rate in sales revenues between $(t+1)$ and $t$

market share $=$ firm market share at 3 -digit primary US SIC

market share (US2) $=$ firm market share at 2-digit primary US SIC

employment $=$ number of firm employees

operating revenue $=$ operating revenue (turnover) in 1000 USD

$\mathrm{K} / \mathrm{L}$ ratio $=$ fixed assets $/$ employment

intangible assets in 1000 of USD

total assets $=$ total firm assets in 1000 of USD

intangible ass. ratio $=$ intangible/total assets

sales in 100 millions of USD

value added $=$ taxation + profit $($ loss $)$ per year + costs of employees

$$
+ \text { depreciation }+ \text { interest paid }
$$

liquidity ratio $=($ current assets - stocks $) /$ current liabilities

return on assets $(\%)=[$ Profit $($ loss $)$ before taxation/total assets $] * 100$

solvency ratio $=$ shareholders funds(including reserves)/total assets

cashflow ratio $=$ cashflow/total assets

profit margin in $(\%)=[[$ (operating revenue - costs of good sold - other operating expenditures $)+$

(financial revenue -financial expenses)]/operating revenue ]*100 
Table 1.3. : Summary statistics of regressors used in growth equation: Full sample - 142 industries with at least 10 domestic firms

\begin{tabular}{|c|c|c|c|c|c|}
\hline $\begin{array}{l}\text { Variable } \\
\text { name }\end{array}$ & $\begin{array}{l}\text { Variable } \\
\text { definition }\end{array}$ & Mean & $\begin{array}{l}\text { Standard } \\
\text { deviation }\end{array}$ & Min & Max \\
\hline growth & $\begin{array}{l}\text { domestic firm sales growth } \\
\text { rate between } t+1 \text { and } t\end{array}$ & 0.094 & 0.589 & -1 & 4.97 \\
\hline FG & $\begin{array}{l}\text { foreign ind. sales growth } \\
\text { rate, between } t+1 \text { and } t\end{array}$ & 0.237 & 1.360 & -1 & 42.14 \\
\hline NCL & $\begin{array}{l}1 \text { if nonclassified firm } \\
\text { included as domestic }\end{array}$ & 0.258 & 0.438 & 0 & 1 \\
\hline FGcl & $\mathrm{FG} *(1-\mathrm{NCL})$ & 0.186 & 1.263 & -1 & 42.14 \\
\hline FGncl & $\mathrm{FG} *(\mathrm{NCL}=1)$ & 0.051 & 0.522 & -1 & 21.14 \\
\hline STATIC & 1 foreign entry into indus. & 0.085 & 0.280 & 0 & 1.00 \\
\hline STATICcI & STATIC*(1-NCL) & 0.063 & 0.243 & 0 & 1.00 \\
\hline STATICncl & STATIC*NCL & 0.022 & 0.147 & 0 & 1.00 \\
\hline NO_FOR & 1 if no foreign presence & 0.179 & 0.132 & 0 & 1.00 \\
\hline aget & firm age since 1989 & 5.471 & 2.383 & 1 & 12.00 \\
\hline ageT2 & ageT*ageT & 35.609 & 27.963 & 1 & 144.00 \\
\hline sales & firm sales revenues & 0.105 & 0.501 & 3.33E-07 & 22.55 \\
\hline sales 2 & sales*sales & 0.262 & 7.303 & $1.11 \mathrm{E}-13$ & 508.34 \\
\hline AS & ageT*sales & 0.598 & 3.017 & 2.00E-06 & 138.07 \\
\hline ES & $\begin{array}{l}\text { foreign employment share } \\
\text { in the industry }\end{array}$ & 0.213 & 0.166 & 0 & 0.98 \\
\hline FORdirect & $\begin{array}{l}\% \text { of foreign ownership } \\
\text { in a firm }\end{array}$ & 2.013 & 10.575 & 0 & 100.00 \\
\hline intang & intangible ass./ total ass. & 0.007 & 0.035 & 0 & 0.96 \\
\hline gap & technology gap (see text) & 0.010 & 0.037 & 0 & 0.94 \\
\hline ESgap & ES*gap & 0.003 & 0.011 & 0 & 0.40 \\
\hline D89 & $\begin{array}{l}1 \text { if a firm founded before } \\
\text { start of transition } 1989\end{array}$ & 0.056 & 0.229 & 0 & 1.00 \\
\hline solvency & shareholder funds/total ass. & 0.388 & 0.331 & -1 & 1.00 \\
\hline konkurz & 1 if firm in bankruptcy & 0.021 & 0.143 & 0 & 1.00 \\
\hline liquidate & 1 if in liquidation & 0.021 & 0.142 & 0 & 1.00 \\
\hline both & 1 if both $B \& L$ & 0.005 & 0.073 & 0 & 1.00 \\
\hline OUT_BR & 1 if out of registrar & 0.008 & 0.089 & 0 & 1.00 \\
\hline IndG & industry growth rate & 0.107 & 0.698 & -0.995 & 23.70 \\
\hline
\end{tabular}

Notes: There is 5705 firms (20462 obs.) out of which 3982 firms is classified domestic (15173 obs.) and 1723 non-classified $(\mathrm{NCL}=1)$ domestic firms (5289 obs.) 
Table 1.4. : Summary statistics of regressors used in exit equation: Full sample - 142 industries with at least 10 domestic firms (6291 firms, 24733 obs.)

\begin{tabular}{|c|c|c|c|c|c|}
\hline $\begin{array}{c}\text { Variable } \\
\text { name }\end{array}$ & Variable definition & Mean & $\begin{array}{l}\text { Standard } \\
\text { deviation }\end{array}$ & Min & $\operatorname{Max}$ \\
\hline El & 1 in year a firm exits & 0.011 & 0.104 & 0 & 1 \\
\hline FG & $\begin{array}{l}\text { foreign ind. sales growth } \\
\text { rate, between } t+1 \text { and } t\end{array}$ & 0.185 & 1.480 & -1 & 42.14 \\
\hline NCL & $\begin{array}{l}1 \text { if nonclassified firm } \\
\text { included as domestic }\end{array}$ & 0.268 & 0.443 & 0 & 1 \\
\hline FGcl & $\mathrm{FG} *(1-\mathrm{NCL})$ & 0.140 & 1.327 & -1 & 42.14 \\
\hline FGncl & $\mathrm{FG} *(\mathrm{NCL})$ & 0.045 & 0.663 & -1 & 42.14 \\
\hline STATIC & 1 if foreign entry into ind. & 0.086 & 0.280 & 0 & 1 \\
\hline STATICcI & STATIC*(1-NCL) & 0.060 & 0.237 & 0 & 1 \\
\hline STATICncl & STATIC*NCL & 0.026 & 0.160 & 0 & 1 \\
\hline NO_FOR & 1 if no foreign presence & 0.018 & 0.131 & 0 & 1 \\
\hline ageT & firm age since 1989 & 5.667 & 2.485 & 1 & 12 \\
\hline ageT2 & ageT*ageT & 38.289 & 30.013 & 1 & 144 \\
\hline sales & firm sales revenues & 0.098 & 0.468 & 3.33E-07 & 22.55 \\
\hline sales2 & sales*sales & 0.228 & 6.676 & $1.11 \mathrm{E}-13$ & 508.34 \\
\hline AS & ageT*sales & 0.573 & 2.866 & $2.00 \mathrm{E}-06$ & 138.07 \\
\hline ES & $\begin{array}{l}\text { foreign employment share } \\
\text { in the industry }\end{array}$ & 0.211 & 0.162 & 0 & 0.98 \\
\hline FORdirect & $\begin{array}{l}\% \text { of foreign ownership } \\
\text { in a firm }\end{array}$ & 2.024 & 10.650 & 0 & 100.00 \\
\hline intang & intangible ass./ total ass. & 0.007 & 0.038 & 0 & 0.99 \\
\hline gap & technology gap (see text) & 0.010 & 0.039 & 0 & 0.98 \\
\hline ESgap & ES*gap & 0.003 & 0.012 & 0 & 0.85 \\
\hline D89 & $\begin{array}{l}1 \text { if a firm founded before } \\
\text { start of transition } 1989\end{array}$ & 0.053 & 0.223 & 0 & 1.00 \\
\hline solvency & shareholder funds/total ass. & 0.380 & 0.335 & -1 & 1.00 \\
\hline IndG & industry growth rate & 0.076 & 0.824 & -0.9946615 & 23.67 \\
\hline
\end{tabular}

Notes: There is 2013 non-classified domestic firms (6619 obs.) and 4278 classified domestic firms (18114 observ.) 
Table 2.1: Growth equation-142 industries, 1994-2001.

\begin{tabular}{|c|c|c|c|c|c|c|c|c|}
\hline \multirow{2}{*}{$\begin{array}{l}\text { Dep. var. } \\
\text { growth rate } \\
\text { FG }\end{array}$} & \multicolumn{2}{|c|}{ OLS with clusters } & \multicolumn{2}{|c|}{ Random effects } & \multicolumn{2}{|c|}{ Fixed effects } & \multicolumn{2}{|c|}{ Pooled tobit } \\
\hline & $\begin{array}{l}0.008 \\
\left(0.00^{\prime}\right)\end{array}$ & & $\begin{array}{l}0.007^{*} \\
(0.004)\end{array}$ & & $\begin{array}{c}0.007 \\
(0.004)\end{array}$ & & $\begin{array}{l}0.008^{*} \\
(0.004)\end{array}$ & \\
\hline FGcl & & $\begin{array}{c}0.01^{*} \\
(0.006)\end{array}$ & & $\begin{array}{l}0.009^{* *} \\
(0.004)\end{array}$ & & $\begin{array}{l}0.009^{\star} \\
(0.005)\end{array}$ & & $\begin{array}{l}0.01^{* *} \\
(0.004)\end{array}$ \\
\hline FGncl & & $\begin{array}{l}-0.006 \\
(0.009)\end{array}$ & & $\begin{array}{l}-0.007 \\
(0.009)\end{array}$ & & $\begin{array}{l}-0.006 \\
(0.01)\end{array}$ & & $\begin{array}{l}-0.006 \\
(0.009)\end{array}$ \\
\hline STATIC & $\begin{array}{c}-0.018 \\
\left(0.034^{\prime}\right)\end{array}$ & & $\begin{array}{c}-0.02 \\
(0.045)\end{array}$ & & $\begin{array}{l}-0.027 \\
(0.047)\end{array}$ & & $\begin{array}{l}-0.017 \\
(0.047)\end{array}$ & \\
\hline STATICcI & & $\begin{array}{l}-0.014 \\
(0.037)\end{array}$ & & $\begin{array}{c}-0.02 \\
(0.046)\end{array}$ & & $\begin{array}{l}-0.045 \\
(0.049)\end{array}$ & & $\begin{array}{l}-0.009 \\
(0.049)\end{array}$ \\
\hline STATICncl & & $\begin{array}{l}-0.021 \\
(0.043)\end{array}$ & & $\begin{array}{l}-0.015 \\
(0.049)\end{array}$ & & $\begin{array}{c}0.009 \\
(0.053)\end{array}$ & & $\begin{array}{l}-0.028 \\
(0.052)\end{array}$ \\
\hline ageT & $\begin{array}{c}-0.215^{* * *} \\
(0.011)\end{array}$ & $\begin{array}{c}-0.214^{\star \star *} \\
(0.011)\end{array}$ & $\begin{array}{c}-0.218^{\star * *} \\
(0.008)\end{array}$ & $\begin{array}{c}-0.218^{\star * *} \\
(0.008)\end{array}$ & $\begin{array}{c}-0.252^{\star * *} \\
(0.017)\end{array}$ & $\begin{array}{c}-0.254^{\star * *} \\
(0.017)\end{array}$ & $\begin{array}{c}-0.217^{* * *} \\
(0.008)\end{array}$ & $\begin{array}{c}-0.216^{* * *} \\
(0.008)\end{array}$ \\
\hline ageT2 & $\begin{array}{c}0.015^{\star * *} \\
(0.011)\end{array}$ & $\begin{array}{c}0.014^{* * *} \\
(0.011)\end{array}$ & $\begin{array}{c}0.015^{* * *} \\
(0.001)\end{array}$ & $\begin{array}{c}0.014^{* * *} \\
(0.001)\end{array}$ & $\begin{array}{c}0.014^{* * *} \\
(0.001)\end{array}$ & $\begin{array}{c}0.014^{* * *} \\
(0.001)\end{array}$ & $\begin{array}{c}0.015^{\star * *} \\
(0.001)\end{array}$ & $\begin{array}{c}0.015^{\star * *} \\
(0.001)\end{array}$ \\
\hline sales & $\begin{array}{c}-0.208^{* * *} \\
(0.03)\end{array}$ & $\begin{array}{c}-0.209^{* * *} \\
(0.03)\end{array}$ & $\begin{array}{c}-0.288^{* * *} \\
(0.034)\end{array}$ & $\begin{array}{c}-0.289^{* * *} \\
(0.034)\end{array}$ & $\begin{array}{c}-0.948^{* * *} \\
(0.067)\end{array}$ & $\begin{array}{c}-0.947^{* * *} \\
(0.067)\end{array}$ & $\begin{array}{c}-0.206^{* * *} \\
(0.029)\end{array}$ & $\begin{array}{c}-0.207^{* * *} \\
(0.029)\end{array}$ \\
\hline sales2 & $\begin{array}{c}0.006^{* * *} \\
(0.011)\end{array}$ & $\begin{array}{c}0.006^{* * *} \\
(0.011)\end{array}$ & $\begin{array}{l}0.01^{* * *} \\
(0.001)\end{array}$ & $\begin{array}{l}0.01^{* * *} \\
(0.001)\end{array}$ & $\begin{array}{c}0.039^{* * *} \\
(0.003)\end{array}$ & $\begin{array}{c}0.039^{\star * *} \\
(0.003)\end{array}$ & $\begin{array}{c}0.006^{* * *} \\
(0.001)\end{array}$ & $\begin{array}{c}0.006^{* * *} \\
(0.001)\end{array}$ \\
\hline AS & $\begin{array}{c}0.015^{\star * *} \\
(0.003)\end{array}$ & $\begin{array}{c}0.015^{\star * *} \\
(0.003)\end{array}$ & $\begin{array}{c}0.018^{* * *} \\
(0.004)\end{array}$ & $\begin{array}{c}0.018^{* * *} \\
(0.004)\end{array}$ & $\begin{array}{c}0.022^{* * *} \\
(0.007)\end{array}$ & $\begin{array}{c}0.022^{* * *} \\
(0.007)\end{array}$ & $\begin{array}{c}0.015^{* * *} \\
(0.003)\end{array}$ & $\begin{array}{c}0.015^{\star \star *} \\
(0.003)\end{array}$ \\
\hline ES & $\begin{array}{c}0.027 \\
(0.138)\end{array}$ & $\begin{array}{c}0.02 \\
(0.139)\end{array}$ & $\begin{array}{c}0.031 \\
(0.112)\end{array}$ & $\begin{array}{c}0.022 \\
(0.113)\end{array}$ & $\begin{array}{c}0.088 \\
(0.123)\end{array}$ & $\begin{array}{c}0.074 \\
(0.123)\end{array}$ & $\begin{array}{c}0.038 \\
(0.117)\end{array}$ & $\begin{array}{c}0.032 \\
(0.118)\end{array}$ \\
\hline FORdirect & $\begin{array}{c}0.001^{*} \\
(0.0003)\end{array}$ & $\begin{array}{l}0.001^{*} \\
(0.001)\end{array}$ & $\begin{array}{c}0.001 \\
0.0001\end{array}$ & $\begin{array}{c}0.001 \\
(0.001)\end{array}$ & $\begin{array}{c}0.001 \\
(0.001)\end{array}$ & $\begin{array}{c}0.001 \\
(0.001)\end{array}$ & $\begin{array}{c}0.001 \\
(0.001)\end{array}$ & $\begin{array}{l}0.001 \\
(0.01)\end{array}$ \\
\hline intang & $\begin{array}{c}0.15 \\
(0.25)\end{array}$ & $\begin{array}{c}0.146 \\
(0.251)\end{array}$ & $\begin{array}{c}0.071 \\
(0.305)\end{array}$ & $\begin{array}{c}0.066 \\
(0.305)\end{array}$ & $\begin{array}{l}-0.405 \\
(0.417)\end{array}$ & $\begin{array}{c}-0.41 \\
(0.417)\end{array}$ & $\begin{array}{c}0.175 \\
(0.286)\end{array}$ & $\begin{array}{c}0.171 \\
(0.286)\end{array}$ \\
\hline gap & $\begin{array}{l}-0.221 \\
(0.369)\end{array}$ & $\begin{array}{l}-0.213 \\
(0.37)\end{array}$ & $\begin{array}{l}-0.074 \\
(0.37)\end{array}$ & $\begin{array}{l}-0.064 \\
(0.37)\end{array}$ & $\begin{array}{c}0.043 \\
(0.465)\end{array}$ & $\begin{array}{c}0.048 \\
(0.465)\end{array}$ & $\begin{array}{l}-0.261 \\
(0.354)\end{array}$ & $\begin{array}{l}-0.251 \\
(0.354)\end{array}$ \\
\hline ESgap & $\begin{array}{c}1.353 \\
(0.953)\end{array}$ & $\begin{array}{c}1.334 \\
(0.954)\end{array}$ & $\begin{array}{c}1.11 \\
(0.854)\end{array}$ & $\begin{array}{c}1.086 \\
(0.854)\end{array}$ & $\begin{array}{c}1.474 \\
(1.178)\end{array}$ & $\begin{array}{c}1.467 \\
(1.178)\end{array}$ & $\begin{array}{c}1.4^{*} \\
-0.793\end{array}$ & $\begin{array}{l}1.378^{*} \\
-0.793\end{array}$ \\
\hline D89 & $\begin{array}{l}-0.031^{*} \\
(0.019)\end{array}$ & $\begin{array}{l}-0.027 \\
(0.019)\end{array}$ & $\begin{array}{l}-0.035 \\
(0.029)\end{array}$ & $\begin{array}{l}-0.032 \\
(0.029)\end{array}$ & dropped & dropped & $\begin{array}{l}-0.034 \\
(0.022)\end{array}$ & $\begin{array}{l}-0.029 \\
(0.023)\end{array}$ \\
\hline solvency & $\begin{array}{c}-0.053^{* * *} \\
(0.015) \\
\end{array}$ & $\begin{array}{c}-0.053^{* \star *} \\
(0.015) \\
\end{array}$ & $\begin{array}{c}-0.048^{\star * *} \\
(0.016)\end{array}$ & $\begin{array}{c}-0.048^{* * *} \\
(0.016)\end{array}$ & $\begin{array}{l}-0.012 \\
(0.033)\end{array}$ & $\begin{array}{l}-0.011 \\
(0.033)\end{array}$ & $\begin{array}{c}-0.051^{\star * *} \\
(0.013)\end{array}$ & $\begin{array}{c}-0.051^{* * *} \\
(0.013)\end{array}$ \\
\hline Observ. & 20462 & 20462 & 20462 & 20462 & 20462 & 20462 & 20462 & 20462 \\
\hline Firms & 5705 & 5705 & 5705 & 5705 & 5705 & 5705 & 5705 & 5705 \\
\hline Censored obs. & 273 & 273 & 273 & 273 & 273 & 273 & 273 & 273 \\
\hline R-squared & 0.17 & 0.17 & 0.17 & 0.17 & 0.18 & 0.18 & 0.106 & 0.106 \\
\hline $\begin{array}{l}\text { LOG-MLE } \\
\text { sigma_u }\end{array}$ & & & 0.239 & 0.24 & & & -16599 & -16596 \\
\hline sigma_e & & & 0.513 & 0.513 & & & $\begin{array}{c}0.543^{* * *} \\
(0.003)\end{array}$ & $\begin{array}{c}0.543^{* * *} \\
(0.003)\end{array}$ \\
\hline $\begin{array}{l}\text { Hausman test } \\
\text { p-value }\end{array}$ & & & $\begin{array}{l}419.4 \\
(0.00) \\
\end{array}$ & $\begin{array}{l}417.33 \\
(0.00) \\
\end{array}$ & & & & \\
\hline
\end{tabular}

Standard errors in parentheses

Estimated coefficients reported, ${ }^{*}$ significant at $10 \%$; ${ }^{* *}$ significant at $5 \%$; ${ }^{* * *}$ significant at $1 \%$.

NOTES:

a) 142 industries include 11 industries without foreign presence. In these industries ES and FG are set $=0$. b) All specifications, but fixed effects, include: constant, year, industry, region, 4 exit type dummies and industry-trend cross-effects. (4 exit dummies code whether a firm ever appears in:liquidation, bankruptcy, both (bankruptcy and liquidation) or is already out of business registrar)

c) Region and 4 exit dummies are dropped in fixed effects model. 
d) Censored observations have growth rate $=-1$.

e) In case of 4 industries when I observe foreign entry during my sample period the entry growth rates are equal to 2 , according to an alternative formula for growth rates: $y(t+1)-y(t) /[y(t+1)+y(t)] / 2$.

f) R2 in random effects corresponds to overall variation, in fixed effects to within variation and in tobit R2 is Pseudo R2.

(Pseudo $\mathrm{R}^{\wedge} 2=1-\mathrm{L} 1 / \mathrm{L} 0$, where L1 is MLE of estimated model and L0 is MLE of "only constant" model.)

SPECIFIC TEST RESULTS:

1) Regional dummies jointly insignificant and industry dummies jointly significant in all specifications.

2) Cross effects (industry $x$ trend) jointly significant in all specifications.

3) Breusch_Pagan test rejects H0: there is no significant unobserved heterogeneity only in specifications without exit dummies.

4) Results the same when ES or exit dummies excluded.

5) Firm level means jointly significant in all specifications. 
Table 2.2: Growth equation-142 industries, 1994-2001

All specifications include firm level means to model firm unobserved heterogeneity.

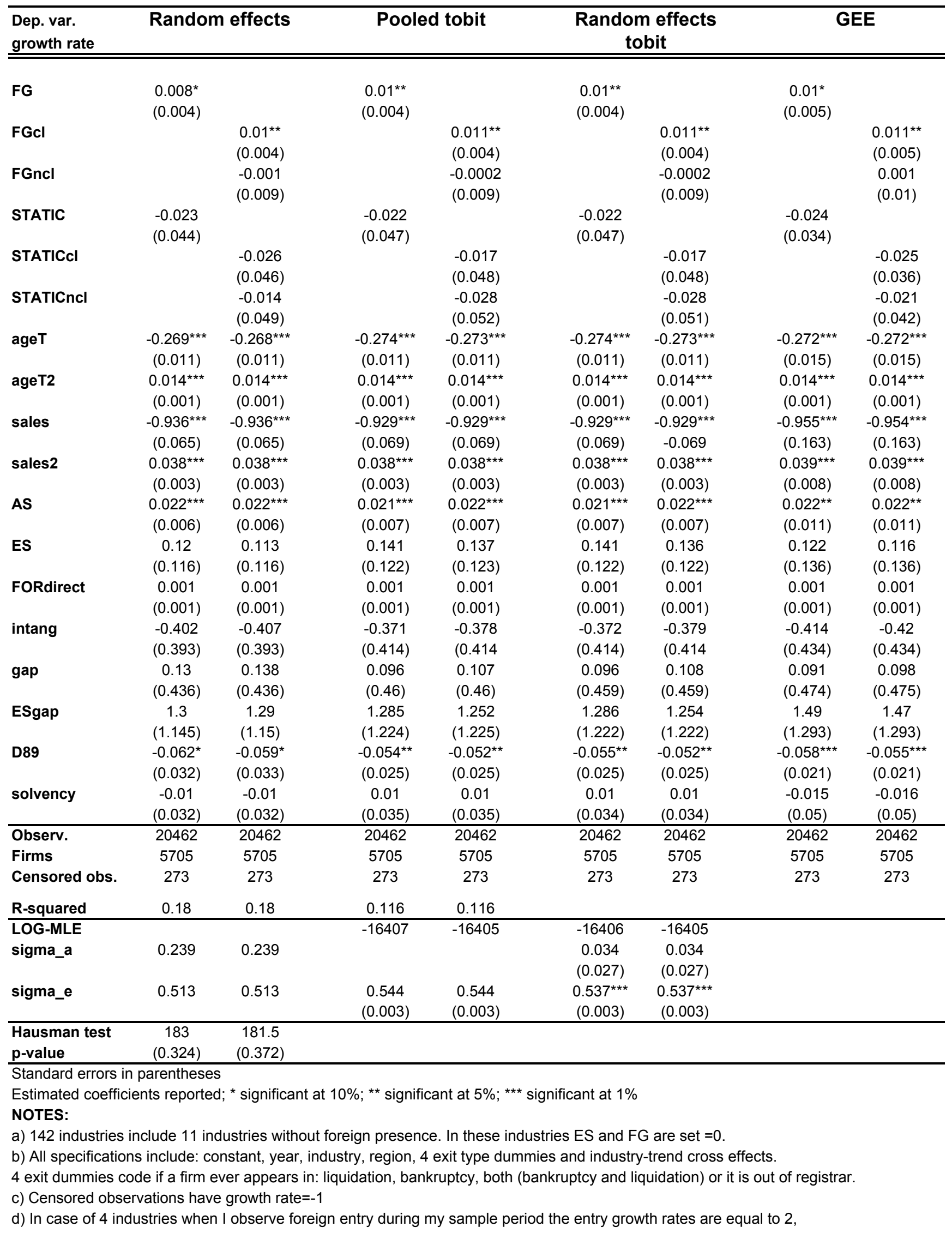


according to an alternative formula for growth rates: $y(t+1)-y(t) /[y(t+1)+y(t)] / 2$.

e) R2 in random effects corresponds to overall variation, in fixed effects to within variation and in tobit R2 is Pseudo R2.

(Pseudo $R^{\wedge} 2=1-L 1 / L 0$, where L1 is MLE of estimated model and L0 is MLE of "only constant" model.)

SPECIFIC TEST RESULTS:

1) In specifications with firm level means Hausman test does not reject the random effects specification at $5 \%$.

2) Regional dummies jointly insignificant and industry dummies jointly significant in all specifications.

3) Cross effects (industry $x$ trend) jointly significant in all specifications.

4) Results the same when ES or exit dummies excluded.

5) Firm level means jointly significant in all specifications. 
Table 3.1. : Exit hazard rates and firm survival, 142 industries, sample period 1994-2001.

\begin{tabular}{|c|c|c|c|c|c|c|c|c|c|c|}
\hline \multirow{3}{*}{$\begin{array}{l}\text { Model } \\
\text { Dep. var. } \\
\text { FG }\end{array}$} & \multicolumn{6}{|c|}{ No firm level means } & \multicolumn{4}{|c|}{ Firm level means to model unobserved heterogeneity } \\
\hline & \multicolumn{3}{|c|}{$\begin{array}{c}\text { Cox } \\
\text { (hazard rate }(\text { Exit=1)) }\end{array}$} & \multicolumn{3}{|c|}{$\begin{array}{l}\text { Lognormal } \\
\text { (time ratio) }\end{array}$} & \multicolumn{2}{|c|}{$\begin{array}{c}\text { Cox } \\
\text { (hazard rate (Exit=1)) }\end{array}$} & \multicolumn{2}{|c|}{$\begin{array}{l}\text { Lognormal } \\
\text { (time ratio) }\end{array}$} \\
\hline & 0.94 & 0.939 & & 1.033 & 1.034 & & $0.695^{\star \star \star}$ & & $1.233^{\star \star \star}$ & \\
\hline & $(0.04)$ & $(0.04)$ & & $(0.021)$ & $(0.022)$ & & $(0.053)$ & & $(0.048)$ & \\
\hline FGcl & & & $\begin{array}{c}0.934 \\
(0.048)\end{array}$ & & & $\begin{array}{c}1.04 \\
(0.029)\end{array}$ & & $\begin{array}{c}0.765^{\star * *} \\
(0.052)\end{array}$ & & $\begin{array}{c}1.167^{* * *} \\
(0.039)\end{array}$ \\
\hline FGncl & & & $\begin{array}{c}0.942 \\
(0.051)\end{array}$ & & & $\begin{array}{c}1.03 \\
(0.033)\end{array}$ & & $\begin{array}{c}0.556^{\star \star *} \\
(0.053)\end{array}$ & & $\begin{array}{c}1.633^{* * *} \\
(0.176)\end{array}$ \\
\hline STATIC & $\begin{array}{c}10.855^{\star \star \star} \\
(2.397)\end{array}$ & $\begin{array}{c}11.020^{* * *} \\
(2.341)\end{array}$ & & $\begin{array}{c}0.254^{* * *} \\
(0.036)\end{array}$ & $\begin{array}{c}0.241^{* * *} \\
(0.03)\end{array}$ & & $\begin{array}{c}10.984^{\star * *} \\
(2.488)\end{array}$ & & $\begin{array}{c}0.214^{\star \star *} \\
(0.03)\end{array}$ & \\
\hline STATICcl & & & $\begin{array}{c}7.215^{\star \star \star} \\
(1.866)\end{array}$ & & & $\begin{array}{c}0.295^{\star \star *} \\
(0.039)\end{array}$ & & $\begin{array}{c}7.021^{* * *} \\
(1.893)\end{array}$ & & $\begin{array}{c}0.268^{\star * *} \\
(0.04)\end{array}$ \\
\hline STATICncl & & & $\begin{array}{c}20.483^{* * *} \\
(5.174)\end{array}$ & & & $\begin{array}{c}0.167^{* * *} \\
(0.028)\end{array}$ & & $\begin{array}{c}21.370^{\star \star *} \\
(5.685)\end{array}$ & & $\begin{array}{c}0.143^{* * *} \\
(0.026)\end{array}$ \\
\hline NO_FOR & & $\begin{array}{c}1.917 \\
(1.111)\end{array}$ & $\begin{array}{c}1.98 \\
(1.156)\end{array}$ & & $\begin{array}{l}0.524^{*} \\
(0.177)\end{array}$ & $\begin{array}{c}0.519^{*} \\
(0.179)\end{array}$ & $\begin{array}{l}3.045^{\star} \\
(1.732)\end{array}$ & $\begin{array}{l}3.083^{\star *} \\
(1.765)\end{array}$ & $\begin{array}{l}0.409^{\star *} \\
(0.145)\end{array}$ & $\begin{array}{l}0.409^{\star *} \\
(0.147)\end{array}$ \\
\hline IndG & $\begin{array}{c}1.045 \\
(0.085)\end{array}$ & $\begin{array}{c}1.047 \\
(0.084)\end{array}$ & $\begin{array}{c}1.046 \\
(0.084)\end{array}$ & $\begin{array}{c}0.985 \\
(0.041)\end{array}$ & $\begin{array}{c}0.982 \\
(0.039)\end{array}$ & $\begin{array}{c}0.986 \\
(0.039)\end{array}$ & $\begin{array}{c}1.036 \\
(0.074)\end{array}$ & $\begin{array}{c}1.03 \\
(0.074)\end{array}$ & $\begin{array}{c}1.002 \\
(0.042)\end{array}$ & $\begin{array}{c}1.001 \\
(0.041)\end{array}$ \\
\hline sales & $\begin{array}{c}0.297 \\
(0.302)\end{array}$ & $\begin{array}{c}0.308 \\
(0.313)\end{array}$ & $\begin{array}{c}0.357 \\
(0.363)\end{array}$ & $\begin{array}{c}1.914 \\
(0.836)\end{array}$ & $\begin{array}{c}1.89 \\
(0.829)\end{array}$ & $\begin{array}{c}1.717 \\
(0.782)\end{array}$ & $\begin{array}{c}0.001^{* * *} \\
(0.002)\end{array}$ & $\begin{array}{c}0.001^{* * *} \\
(0.001)\end{array}$ & $\begin{array}{c}19.514^{\star \star *} \\
(20.7)\end{array}$ & $\begin{array}{c}24.240^{* * \star} \\
(26.61)\end{array}$ \\
\hline sales2 & $\begin{array}{c}0.942 \\
(0.499)\end{array}$ & $\begin{array}{c}0.924 \\
(0.498)\end{array}$ & $\begin{array}{c}0.861 \\
(0.489)\end{array}$ & $\begin{array}{c}1.004 \\
(0.224)\end{array}$ & $\begin{array}{c}1.009 \\
(0.227)\end{array}$ & $\begin{array}{c}1.069 \\
(0.275)\end{array}$ & $\begin{array}{c}5.622^{* * *} \\
(3.354)\end{array}$ & $\begin{array}{c}6.547^{\star * *} \\
(4.456)\end{array}$ & $\begin{array}{c}0.494^{\star \star *} \\
(0.108)\end{array}$ & $\begin{array}{c}0.448^{\star * *} \\
(0.117)\end{array}$ \\
\hline ES & $\begin{array}{c}1.25 \\
(0.872)\end{array}$ & $\begin{array}{c}1.479 \\
(1.025)\end{array}$ & $\begin{array}{c}1.415 \\
(0.986)\end{array}$ & $\begin{array}{c}0.939 \\
(0.323)\end{array}$ & $\begin{array}{c}0.779 \\
(0.246)\end{array}$ & $\begin{array}{c}0.786 \\
(0.264)\end{array}$ & $\begin{array}{l}0.089^{*} \\
(0.118)\end{array}$ & $\begin{array}{l}0.072^{\star *} \\
(0.094)\end{array}$ & $\begin{array}{l}3.831^{\text {** }}(2.456)\end{array}$ & $\begin{array}{l}4.185^{\star *} \\
(2.736)\end{array}$ \\
\hline FORdirect & $\begin{array}{c}0.983 \\
(0.011)\end{array}$ & $\begin{array}{c}0.983 \\
(0.011)\end{array}$ & $\begin{array}{c}0.985 \\
(0.011)\end{array}$ & $\begin{array}{c}1.006 \\
(0.004)\end{array}$ & $\begin{array}{c}1.006 \\
(0.004)\end{array}$ & $\begin{array}{c}1.006 \\
(0.004)\end{array}$ & $\begin{array}{c}1.011 \\
(0.016)\end{array}$ & $\begin{array}{c}1.012 \\
(0.014)\end{array}$ & $\begin{array}{c}0.991 \\
(0.008)\end{array}$ & $\begin{array}{c}0.991 \\
(0.008)\end{array}$ \\
\hline intang & $\begin{array}{c}0.929 \\
(2.386)\end{array}$ & $\begin{array}{c}0.535 \\
(1.295)\end{array}$ & $\begin{array}{c}0.679 \\
(1.612)\end{array}$ & $\begin{array}{c}0.491 \\
(0.648)\end{array}$ & $\begin{array}{c}0.839 \\
(1.034)\end{array}$ & $\begin{array}{c}0.57 \\
(0.697)\end{array}$ & $\begin{array}{c}373 \\
(1481)\end{array}$ & $\begin{array}{c}454 \\
(1888)\end{array}$ & $\begin{array}{c}0.051 \\
(0.129)\end{array}$ & $\begin{array}{c}0.038 \\
(0.102)\end{array}$ \\
\hline gap & $\begin{array}{c}10.985 \\
(37.401)\end{array}$ & $\begin{array}{c}23.62 \\
(78)\end{array}$ & $\begin{array}{l}16.919 \\
(55.34)\end{array}$ & $\begin{array}{c}0.456 \\
(0.777)\end{array}$ & $\begin{array}{c}0.217 \\
(0.348)\end{array}$ & $\begin{array}{c}0.336 \\
(0.544)\end{array}$ & $\begin{array}{l}1.968 \\
(10.4)\end{array}$ & $\begin{array}{l}1.548 \\
(8.62)\end{array}$ & $\begin{array}{c}1.445 \\
(4.142)\end{array}$ & $\begin{array}{l}1.819 \\
(5.48)\end{array}$ \\
\hline Esgap & $\begin{array}{l}0.0003 \\
(0.003)\end{array}$ & $\begin{array}{l}0.0001 \\
(0.001)\end{array}$ & $\begin{array}{l}0.0001 \\
(0.001)\end{array}$ & $\begin{array}{l}61.5 \\
(296)\end{array}$ & $\begin{array}{c}137 \\
(663)\end{array}$ & $\begin{array}{c}127 \\
(628)\end{array}$ & $\begin{array}{c}0.0001 \mathrm{~d}) \\
(0.001)\end{array}$ & $\begin{array}{c}0.08 \mathrm{~d}) \\
(0.8)\end{array}$ & $\begin{array}{l}23 \mathrm{~d}) \\
(205)\end{array}$ & $\begin{array}{c}39 \\
(359)\end{array}$ \\
\hline D89 & $\begin{array}{l}0.595 \\
(0.284\end{array}$ & $\begin{array}{c}0.589 \\
(0.282)\end{array}$ & $\begin{array}{l}0.441^{*} \\
(0.212)\end{array}$ & $\begin{array}{l}1.790^{* * *} \\
(0.325)\end{array}$ & $\begin{array}{c}1.796^{* * *} \\
(0.327\end{array}$ & $\begin{array}{c}2.042^{* * *} \\
(0.385)\end{array}$ & $\begin{array}{c}0.669 \\
(0.321)\end{array}$ & $\begin{array}{c}0.518 \\
(0.249)\end{array}$ & $\begin{array}{l}1.946^{* * *} \\
(0.368)\end{array}$ & $\begin{array}{c}2.217^{\star * *} \\
(0.432)\end{array}$ \\
\hline solvency & $\begin{array}{c}0.262^{* * *} \\
(0.048)\end{array}$ & $\begin{array}{c}0.262^{* * *} \\
(0.048)\end{array}$ & $\begin{array}{c}0.268^{* * *} \\
(0.049) \\
\end{array}$ & $\begin{array}{c}1.986^{* * *} \\
(0.187) \\
\end{array}$ & $\begin{array}{l}1.990^{* * *} \\
(0.188)\end{array}$ & $\begin{array}{c}1.978^{* * *} \\
(0.19) \\
\end{array}$ & $\begin{array}{c}0.080^{* * *} \\
(0.027)\end{array}$ & $\begin{array}{c}0.078^{* * *} \\
(0.027) \\
\end{array}$ & $\begin{array}{c}5.446^{* * *} \\
(1.645) \\
\end{array}$ & $\begin{array}{c}5.480^{* * *} \\
(1.694) \\
\end{array}$ \\
\hline Observ. & 24733 & 24733 & 24733 & 24733 & 24733 & 24733 & 24733 & 24733 & 24733 & 24733 \\
\hline Firms & 6291 & 6291 & 6291 & 6291 & 6291 & 6291 & 6291 & 6291 & 6291 & 6291 \\
\hline exits & 273 & 273 & 273 & 273 & 273 & 273 & 273 & 273 & 273 & 273 \\
\hline $\begin{array}{l}\text { Log-MLE } \\
\text { In_sigma }\end{array}$ & -1896 & -1895 & -1886 & $\begin{array}{c}-797 \\
-0.091 \\
(0.065)\end{array}$ & $\begin{array}{c}-795 \\
-0.094 \\
(0.065)\end{array}$ & $\begin{array}{c}-786 \\
-0.087 \\
(0.066)\end{array}$ & -1856 & -1845 & $\begin{array}{l}-761 \\
-0.05 \\
(0.07)\end{array}$ & $\begin{array}{c}-751 \\
-0.42 \\
(0.047)\end{array}$ \\
\hline
\end{tabular}

Robust standard errors with clusters on firms in parentheses

Exponentiated coefficients $\exp \{x b\}$ reported, * significant at $10 \%$; ** significant at $5 \%$; ${ }^{* * *}$ significant at $1 \%$ 
NOTES:

a) All specifications include: annual re-grouped dummies, industry re-grouped dummies, regional dummies

b) Standard errors of exponentiated coefficients are calculated by Delta method.

However, Wald test results for significance of individual coefficients are based on natural regression coefficients, because of skewed distribution of hazard/time ratios

c) Cox regression uses Efron method for ties.

d) For presentation purposes exponentiated coefficients and standard errors are divided by 1000 in Log normal model and multiplied by 1000 in hazard rate models.

\section{SPECIFIC TEST RESULTS:}

1) Firm level means jointly significant in all specifications.

2) The results do not change when variables IndG or ES excluded.

3) Regional dummies jointly insignificant in all specifications.

4) Industry dummies jointly significant in all specifications.

5) $\mathrm{F}$ test in specifications without means does not reject $\mathrm{HO}$ : $\mathrm{FGcl}=\mathrm{FGncl}$ and $\mathrm{HO}$ : STATICcl=STATICncl, both at $5 \%$ significance level.

6) $\mathrm{F}$ test in specifications with means does reject $\mathrm{HO}$ : $\mathrm{FGcl}=\mathrm{FGncl}$ and $\mathrm{HO}$ : STATICcl=STATICncl, both at $5 \%$ significance level. 
Table 3.2.: Firm Exit: Probit model - 142 industries, sample period 1994-2001.

\begin{tabular}{|c|c|c|c|c|c|c|}
\hline \multirow{2}{*}{$\begin{array}{l}\text { Dep. var. } \\
\text { Exit=1 } \\
\text { FG }\end{array}$} & \multicolumn{3}{|c|}{ No firm level means } & \multicolumn{3}{|c|}{$\begin{array}{l}\text { Firm level means to model } \\
\text { unobserved heterogeneity }\end{array}$} \\
\hline & $\begin{array}{l}-0.027 \\
(0.017)\end{array}$ & $\begin{array}{l}-0.027 \\
(0.017)\end{array}$ & & $\begin{array}{c}-0.160^{* * *} \\
(0.027)\end{array}$ & $\begin{array}{l}-0.162^{* \star *} \\
(0.027)\end{array}$ & \\
\hline FGcl & & & $\begin{array}{c}-0.03 \\
(0.021)\end{array}$ & & & $\begin{array}{c}-0.120^{\star \star *} \\
(0.025)\end{array}$ \\
\hline FGncl & & & $\begin{array}{l}-0.025 \\
(0.026)\end{array}$ & & & $\begin{array}{c}-0.308^{\star * *} \\
(0.057)\end{array}$ \\
\hline STATIC & $\begin{array}{c}1.066^{* * *} \\
(0.098)\end{array}$ & $\begin{array}{c}1.086^{* * *} \\
(0.087)\end{array}$ & & $\begin{array}{c}1.083^{* \star *} \\
(0.107)\end{array}$ & $\begin{array}{c}1.116^{\star \star *} \\
(0.092)\end{array}$ & \\
\hline STATICcI & & & $\begin{array}{c}0.890^{* * *} \\
(0.104\end{array}$ & & & $\begin{array}{c}0.908^{* * *} \\
(0.109)\end{array}$ \\
\hline STATICncl & & & $\begin{array}{c}1.393^{* * *} \\
(0.111)\end{array}$ & & & $\begin{array}{c}1.437^{* * *} \\
(0.115)\end{array}$ \\
\hline NO_FOR & & $\begin{array}{c}0.354 \\
(0.244)\end{array}$ & $\begin{array}{c}0.359 \\
(0.247)\end{array}$ & & $\begin{array}{l}0.540^{\star *} \\
(0.242)\end{array}$ & $\begin{array}{l}0.539^{* *} \\
(0.244)\end{array}$ \\
\hline IndG & $\begin{array}{c}0.013 \\
(0.034)\end{array}$ & $\begin{array}{c}0.015 \\
(0.034)\end{array}$ & $\begin{array}{c}0.013 \\
(0.034)\end{array}$ & $\begin{array}{l}-0.003 \\
(0.033)\end{array}$ & $\begin{array}{l}-0.001 \\
(0.033)\end{array}$ & $\begin{array}{l}0.0004 \\
(0.032)\end{array}$ \\
\hline aget & $\begin{array}{c}0.132^{* * *} \\
(0.047)\end{array}$ & $\begin{array}{c}0.133^{* * *} \\
(0.047)\end{array}$ & $\begin{array}{l}0.113^{* *} \\
(0.047)\end{array}$ & $\begin{array}{c}0.128^{* * *} \\
(0.047)\end{array}$ & $\begin{array}{c}0.129^{* * *} \\
(0.047)\end{array}$ & $\begin{array}{l}0.116^{\star *} \\
(0.048)\end{array}$ \\
\hline ageT2 & $\begin{array}{c}-0.009^{\star *} \\
(0.004)\end{array}$ & $\begin{array}{c}-0.009^{* *} \\
(0.004)\end{array}$ & $\begin{array}{l}-0.007^{*} \\
(0.004)\end{array}$ & $\begin{array}{c}-0.010^{* *} \\
(0.004)\end{array}$ & $\begin{array}{c}-0.010^{* *} \\
(0.004)\end{array}$ & $\begin{array}{c}-0.009^{* *} \\
(0.004)\end{array}$ \\
\hline sales & $\begin{array}{l}-0.692 \\
(0.481)\end{array}$ & $\begin{array}{c}-0.67 \\
(0.484)\end{array}$ & $\begin{array}{c}-0.44 \\
(0.515)\end{array}$ & $\begin{array}{c}-3.128^{\star * *} \\
(1.101)\end{array}$ & $\begin{array}{c}-3.108^{* * *} \\
(1.107)\end{array}$ & $\begin{array}{c}-3.023^{\star * *} \\
(1.089)\end{array}$ \\
\hline sales2 & $\begin{array}{l}-0.052 \\
(0.212)\end{array}$ & $\begin{array}{l}-0.055 \\
(0.213)\end{array}$ & $\begin{array}{l}-0.077 \\
(0.222)\end{array}$ & $\begin{array}{c}0.698^{* * *} \\
(0.208)\end{array}$ & $\begin{array}{c}0.698^{* * *} \\
(0.208)\end{array}$ & $\begin{array}{c}0.757^{* * *} \\
(0.23)\end{array}$ \\
\hline AS & $\begin{array}{c}0.042 \\
(0.069)\end{array}$ & $\begin{array}{c}0.04 \\
(0.069)\end{array}$ & $\begin{array}{c}0.012 \\
(0.074)\end{array}$ & $\begin{array}{c}0.029 \\
(0.109)\end{array}$ & $\begin{array}{l}0.024 \\
(0.11)\end{array}$ & $\begin{array}{l}-0.008 \\
(0.115)\end{array}$ \\
\hline ES & $\begin{array}{c}0.041 \\
(0.279)\end{array}$ & $\begin{array}{c}0.14 \\
(0.273)\end{array}$ & $\begin{array}{c}0.13 \\
(0.282)\end{array}$ & $\begin{array}{c}-1.246^{* *} \\
(0.531)\end{array}$ & $\begin{array}{c}-1.233^{* *} \\
(0.531)\end{array}$ & $\begin{array}{c}-1.291^{* *} \\
(0.536)\end{array}$ \\
\hline FORdirect & $\begin{array}{l}-0.006 \\
(0.004)\end{array}$ & $\begin{array}{l}-0.006 \\
(0.004)\end{array}$ & $\begin{array}{l}-0.005 \\
(0.004)\end{array}$ & $\begin{array}{c}0.005 \\
(0.007)\end{array}$ & $\begin{array}{c}0.005 \\
(0.007)\end{array}$ & $\begin{array}{c}0.005 \\
(0.006)\end{array}$ \\
\hline intang & $\begin{array}{c}0.139 \\
(1.003)\end{array}$ & $\begin{array}{l}-0.189 \\
(0.971)\end{array}$ & $\begin{array}{l}-0.017 \\
(0.954)\end{array}$ & $\begin{array}{c}2.789 \\
(1.911)\end{array}$ & $\begin{array}{c}2.487 \\
(1.853)\end{array}$ & $\begin{array}{c}2.553 \\
(1.924)\end{array}$ \\
\hline gap & $\begin{array}{c}0.698 \\
(1.339)\end{array}$ & $\begin{array}{c}1.143 \\
(1.326)\end{array}$ & $\begin{array}{c}0.916 \\
(1.326)\end{array}$ & $\begin{array}{l}-0.048 \\
(2.242)\end{array}$ & $\begin{array}{c}0.289 \\
(2.207)\end{array}$ & $\begin{array}{c}0.281 \\
(2.277)\end{array}$ \\
\hline ESgap & $\begin{array}{l}-2.453 \\
(4.218)\end{array}$ & $\begin{array}{l}-2.915 \\
(4.342)\end{array}$ & $\begin{array}{l}-2.837 \\
(4.46)\end{array}$ & $\begin{array}{l}-8.314 \\
(8.01)\end{array}$ & $\begin{array}{l}-8.737 \\
(8.069)\end{array}$ & $\begin{array}{l}-9.144 \\
(8.339)\end{array}$ \\
\hline D89 & $\begin{array}{l}-0.178 \\
(0.162)\end{array}$ & $\begin{array}{l}-0.183 \\
(0.162)\end{array}$ & $\begin{array}{l}-0.310^{*} \\
(0.167)\end{array}$ & $\begin{array}{l}-0.132 \\
(0.162)\end{array}$ & $\begin{array}{l}-0.137 \\
(0.162)\end{array}$ & $\begin{array}{l}-0.249 \\
(0.166)\end{array}$ \\
\hline solvency & $\begin{array}{c}-0.558^{\star * *} \\
(0.08)\end{array}$ & $\begin{array}{c}-0.559^{* * *} \\
(0.08) \\
\end{array}$ & $\begin{array}{c}-0.553^{* * *} \\
(0.081) \\
\end{array}$ & $\begin{array}{c}-1.262^{* * *} \\
(0.188)\end{array}$ & $\begin{array}{c}-1.264^{\star * *} \\
(0.189)\end{array}$ & $\begin{array}{c}-1.262^{* \star *} \\
(0.191)\end{array}$ \\
\hline Observ. & 24733 & 24733 & 24733 & 24733 & 24733 & 24733 \\
\hline Firms & 6291 & 6291 & 6291 & 6291 & 6291 & 6291 \\
\hline exits & 273 & 273 & 273 & 273 & 273 & 273 \\
\hline Log-MLE & -1248 & -1241 & -1231 & -1200 & -1198 & -1187 \\
\hline Pseudo R2 & 0.17 & 0.178 & 0.18 & 0.2 & 0.202 & 0.21 \\
\hline
\end{tabular}

Robust standard errors in parentheses with clusters on firms

Estimated coefficients reported; * significant at $10 \%$; ${ }^{* *}$ significant at $5 \%$; ${ }^{* * *}$ significant at $1 \%$.

NOTES:

1) All specifications include: constant, re-grouped industry, re-grouped year and regional dummies.

2) Heterogeneity is modeled by firm level means of the following variables:

FG, sales, sales2, ES, intang, gap, FORdirect, ESgap, solvency.

3) Firm level means jointly significant in all specifications.

4) Industry dummies jointly significant in all specifications.

5) Regional dummies jointly insignificant in all specifications.

6) RE probit results the same as pooled probit with clusters. LR test does not reject H0: no unobserved heterogeneity.

7) The results are similar when clusters on industry-year instead of firm are specified (see the main text). 
Table 4.1.: Growth equation. 142 industries, sample period 1994-2001.

Alternative specifications include firm level means to model unobserved heterogeneity.

\begin{tabular}{|c|c|c|c|c|c|c|c|c|c|c|c|c|}
\hline \multirow[t]{2}{*}{ Sample } & \multirow{2}{*}{\multicolumn{2}{|c|}{$\begin{array}{l}\text { Dummy NO_FOR=1 if } \\
\text { no foreign presence }\end{array}$}} & \multirow{2}{*}{\multicolumn{2}{|c|}{$\begin{array}{c}\text { I) exclude indust. With } \\
\text { no foreign presence }\end{array}$}} & \multirow{2}{*}{\multicolumn{2}{|c|}{$\begin{array}{l}\text { II) exclude I) and } \\
4 \text { entry industries }\end{array}$}} & \multirow{2}{*}{\multicolumn{2}{|c|}{$\begin{array}{l}\text { III) only positive } \\
\text { Foreign Growth } \\
\end{array}$}} & \multicolumn{4}{|c|}{ IV) TECHNOLOGY } \\
\hline & & & & & & & & & LAGC & ARDS & LEA & DERS \\
\hline$\overline{\overline{\text { FG }}}$ & $\begin{array}{c}0.01^{* *} \\
(0.004)\end{array}$ & & $\begin{array}{l}0.01^{* *} \\
(0.004)\end{array}$ & & $\begin{array}{l}0.01^{* *} \\
(0.004)\end{array}$ & & $\begin{array}{l}0.013^{\star *} \\
(0.005)\end{array}$ & & $\begin{array}{c}0.002 \\
(0.008)\end{array}$ & & $\begin{array}{c}0.01^{*} \\
(0.005)\end{array}$ & \\
\hline FGcl & & $\begin{array}{l}0.011^{* *} \\
(0.005)\end{array}$ & & $\begin{array}{l}0.011^{* *} \\
(0.005)\end{array}$ & & $\begin{array}{l}0.011^{\text {** }} \\
(0.005)\end{array}$ & & $\begin{array}{l}0.014^{* *} \\
(0.005)\end{array}$ & & $\begin{array}{c}0.005 \\
(0.009)\end{array}$ & & $\begin{array}{l}0.01^{*} \\
(0.005)\end{array}$ \\
\hline FGncl & & $\begin{array}{l}0.002 \\
(0.01)\end{array}$ & & $\begin{array}{l}0.003 \\
(0.01)\end{array}$ & & $\begin{array}{l}0.002 \\
(0.01)\end{array}$ & & $\begin{array}{c}0.005 \\
(0.012)\end{array}$ & & $\begin{array}{c}0.009 \\
(0.014)\end{array}$ & & $\begin{array}{c}0.008 \\
(0.015)\end{array}$ \\
\hline STATIC & $\begin{array}{l}-0.023 \\
(0.047)\end{array}$ & & $\begin{array}{l}-0.033 \\
(0.05)\end{array}$ & & $\begin{array}{l}-0.032 \\
-0.05\end{array}$ & & $\begin{array}{l}-0.048 \\
(0.067)\end{array}$ & & $\begin{array}{l}-0.011 \\
(0.068)\end{array}$ & & $\begin{array}{l}-0.016 \\
(0.067\end{array}$ & \\
\hline STATICcl & & $\begin{array}{l}-0.018 \\
(0.048)\end{array}$ & & $\begin{array}{l}-0.028 \\
(0.051)\end{array}$ & & $\begin{array}{l}-0.027 \\
(0.051)\end{array}$ & & $\begin{array}{l}-0.057 \\
(0.069)\end{array}$ & & $\begin{array}{l}-0.027 \\
(0.072)\end{array}$ & & $\begin{array}{l}-0.009 \\
(0.068)\end{array}$ \\
\hline STATICncl & & $\begin{array}{l}-0.029 \\
(0.052)\end{array}$ & & $\begin{array}{l}-0.038 \\
(0.054)\end{array}$ & & $\begin{array}{l}-0.038 \\
(0.054)\end{array}$ & & $\begin{array}{l}-0.031 \\
(0.07)\end{array}$ & & $\begin{array}{c}0.009 \\
(0.073)\end{array}$ & & $\begin{array}{l}-0.036 \\
(0.074)\end{array}$ \\
\hline NO_FOR & $\begin{array}{l}0.055 \\
(0.33)\end{array}$ & $\begin{array}{l}0.052 \\
(0.33)\end{array}$ & & & & & & & & & & \\
\hline ageT & $\begin{array}{c}-0.274^{\star \star \star} \\
(0.011)\end{array}$ & $\begin{array}{c}-0.273^{* * *} \\
(0.011)\end{array}$ & $\begin{array}{c}-0.272^{\star * *} \\
(0.011)\end{array}$ & $\begin{array}{c}-0.271^{\star * *} \\
(0.011)\end{array}$ & $\begin{array}{c}-0.273^{\star * *} \\
(0.011)\end{array}$ & $\begin{array}{c}-0.272^{\star \star \star} \\
(0.012)\end{array}$ & $\begin{array}{c}-0.291^{* * *} \\
(0.015)\end{array}$ & $\begin{array}{c}-0.291^{\star \star *} \\
(0.015)\end{array}$ & $\begin{array}{c}-0.232^{\star \star \star} \\
(0.019)\end{array}$ & $\begin{array}{c}-0.233^{\star * *} \\
(0.019)\end{array}$ & $\begin{array}{c}-0.289^{* \star *} \\
(0.014)\end{array}$ & $\begin{array}{c}-0.287^{\star \star *} \\
(0.014)\end{array}$ \\
\hline ageT2 & $\begin{array}{c}0.014^{\star \star \star} \\
(0.001)\end{array}$ & $\begin{array}{c}0.014^{* * *} \\
(0.001)\end{array}$ & $\begin{array}{c}0.014^{* * *} \\
(0.001)\end{array}$ & $\begin{array}{c}0.014^{\star \star *} \\
(0.001)\end{array}$ & $\begin{array}{c}0.014^{\star \star *} \\
(0.001)\end{array}$ & $\begin{array}{c}0.014^{* * *} \\
(0.001)\end{array}$ & $\begin{array}{c}0.015^{\star * *} \\
(0.001)\end{array}$ & $\begin{array}{c}0.015^{\star * *} \\
(0.001)\end{array}$ & $\begin{array}{c}0.012^{* * *} \\
(0.001)\end{array}$ & $\begin{array}{c}0.012^{\star * *} \\
(0.001)\end{array}$ & $\begin{array}{c}0.015^{\star \star *} \\
(0.001)\end{array}$ & $\begin{array}{c}0.015^{\star \star *} \\
(0.001)\end{array}$ \\
\hline sales & $\begin{array}{c}-0.929^{\star \star \star} \\
(0.069)\end{array}$ & $\begin{array}{c}-0.929^{* * *} \\
(0.069)\end{array}$ & $\begin{array}{c}-0.969^{* * *} \\
(0.071)\end{array}$ & $\begin{array}{c}-0.969^{\star \star *} \\
(0.071)\end{array}$ & $\begin{array}{c}-0.966^{* * *} \\
(0.071)\end{array}$ & $\begin{array}{c}-0.966^{\star * *} \\
(0.071)\end{array}$ & $\begin{array}{l}-1.4^{\star \star \star} \\
(0.108)\end{array}$ & $\begin{array}{c}-1.398^{\star \star \star} \\
(0.108)\end{array}$ & $\begin{array}{c}-1.456^{\star \star *} \\
(0.140)\end{array}$ & $\begin{array}{c}-1.458^{\star \star *} \\
(0.140)\end{array}$ & $\begin{array}{c}-0.815^{\star * *} \\
(0.083)\end{array}$ & $\begin{array}{c}-0.814^{\star * *} \\
(0.083)\end{array}$ \\
\hline sales2 & $\begin{array}{c}0.038^{* * *} \\
(0.003)\end{array}$ & $\begin{array}{c}0.038^{* * *} \\
(0.003)\end{array}$ & $\begin{array}{c}0.039^{* * *} \\
(0.003)\end{array}$ & $\begin{array}{c}0.039^{* * *} \\
(0.003)\end{array}$ & $\begin{array}{c}0.039^{* * *} \\
(0.003)\end{array}$ & $\begin{array}{c}0.039^{* * *} \\
(0.003)\end{array}$ & $\begin{array}{c}0.067^{* * *} \\
(0.006)\end{array}$ & $\begin{array}{c}0.067^{* * *} \\
(0.006)\end{array}$ & $\begin{array}{c}0.063^{* * *} \\
(0.006)\end{array}$ & $\begin{array}{c}0.063^{* * *} \\
(0.006)\end{array}$ & $\begin{array}{c}0.032^{* * *} \\
(0.004)\end{array}$ & $\begin{array}{c}0.032^{* * *} \\
(0.004)\end{array}$ \\
\hline AS & $\begin{array}{c}0.021^{* * *} \\
(0.007)\end{array}$ & $\begin{array}{c}0.022^{* * *} \\
(0.007)\end{array}$ & $\begin{array}{l}0.016^{* *} \\
(0.007)\end{array}$ & $\begin{array}{l}0.016^{* *} \\
(0.007)\end{array}$ & $\begin{array}{l}0.016^{* *} \\
(0.007)\end{array}$ & $\begin{array}{l}0.016^{* *} \\
(0.007)\end{array}$ & $\begin{array}{c}0.041^{* * *} \\
(0.010)\end{array}$ & $\begin{array}{c}0.041^{* * *} \\
(0.010)\end{array}$ & $\begin{array}{l}-0.003 \\
(0.017)\end{array}$ & $\begin{array}{l}-0.003 \\
(0.017)\end{array}$ & $\begin{array}{l}0.014^{*} \\
(0.008)\end{array}$ & $\begin{array}{l}0.014^{*} \\
(0.008)\end{array}$ \\
\hline ES & $\begin{array}{c}0.142 \\
(0.122)\end{array}$ & $\begin{array}{c}0.138 \\
(0.123)\end{array}$ & $\begin{array}{c}0.139 \\
(0.122)\end{array}$ & $\begin{array}{c}0.136 \\
(0.123)\end{array}$ & $\begin{array}{c}0.143 \\
(0.123)\end{array}$ & $\begin{array}{c}0.139 \\
(0.123)\end{array}$ & $\begin{array}{c}0.252 \\
(0.166)\end{array}$ & $\begin{array}{c}0.233 \\
(0.166)\end{array}$ & $\begin{array}{l}-0.214 \\
(0.212)\end{array}$ & $\begin{array}{l}-0.207 \\
(0.212)\end{array}$ & $\begin{array}{l}0.321^{* *} \\
-0.155\end{array}$ & $\begin{array}{c}0.316^{* *} \\
-0.155\end{array}$ \\
\hline FORdirect & $\begin{array}{c}0.001 \\
(0.001)\end{array}$ & $\begin{array}{c}0.001 \\
(0.001)\end{array}$ & $\begin{array}{c}0.001 \\
(0.001)\end{array}$ & $\begin{array}{c}0.001 \\
(0.001)\end{array}$ & $\begin{array}{c}0.001 \\
(0.001)\end{array}$ & $\begin{array}{c}0.001 \\
(0.001)\end{array}$ & $\begin{array}{c}0.001 \\
(0.001)\end{array}$ & $\begin{array}{c}0.001 \\
(0.001)\end{array}$ & $\begin{array}{c}0.002 \\
(0.001)\end{array}$ & $\begin{array}{c}0.002 \\
(0.001)\end{array}$ & $\begin{array}{l}0.0003 \\
(0.001)\end{array}$ & $\begin{array}{l}0.0003 \\
(0.001)\end{array}$ \\
\hline intang & $\begin{array}{l}-0.372 \\
(0.414)\end{array}$ & $\begin{array}{l}-0.376 \\
(0.414)\end{array}$ & $\begin{array}{l}-0.431 \\
(0.444)\end{array}$ & $\begin{array}{l}-0.436 \\
(0.444)\end{array}$ & $\begin{array}{l}-0.849 \\
(0.707)\end{array}$ & $\begin{array}{l}-0.856 \\
(0.708)\end{array}$ & $\begin{array}{l}-0.613 \\
(0.564)\end{array}$ & $\begin{array}{c}-0.61 \\
(0.564)\end{array}$ & $\begin{array}{l}-0.058 \\
(0.721)\end{array}$ & $\begin{array}{l}-0.078 \\
(0.721)\end{array}$ & $\begin{array}{c}-5.011^{\star \star \star} \\
(1.498)\end{array}$ & $\begin{array}{l}-4.99^{\star \star \star *} \\
(1.498)\end{array}$ \\
\hline gap & $\begin{array}{l}0.096 \\
(0.46)\end{array}$ & $\begin{array}{l}0.105 \\
(0.46)\end{array}$ & $\begin{array}{c}0.116 \\
(0.474)\end{array}$ & $\begin{array}{c}0.124 \\
(0.474)\end{array}$ & $\begin{array}{c}0.582 \\
(0.779)\end{array}$ & $\begin{array}{c}0.592 \\
(0.779)\end{array}$ & $\begin{array}{l}0.226 \\
(0.59)\end{array}$ & $\begin{array}{l}0.223 \\
(0.59)\end{array}$ & $\begin{array}{l}0.008 \\
(0.691)\end{array}$ & $\begin{array}{c}0.036 \\
(0.693)\end{array}$ & $\begin{array}{c}4.776^{\star * *} \\
(1.564)\end{array}$ & $\begin{array}{c}4.755^{* * *} \\
(1.564)\end{array}$ \\
\hline ESgap & $\begin{array}{c}1.284 \\
(1.224)\end{array}$ & $\begin{array}{c}1.259 \\
(1.225)\end{array}$ & $\begin{array}{c}1.31 \\
(1.227)\end{array}$ & $\begin{array}{c}1.286 \\
(1.227)\end{array}$ & $\begin{array}{c}1.214 \\
(1.237)\end{array}$ & $\begin{array}{c}1.189 \\
(1.237)\end{array}$ & $\begin{array}{c}0.433 \\
(1.686)\end{array}$ & $\begin{array}{c}0.428 \\
(1.687)\end{array}$ & $\begin{array}{c}0.658 \\
(2.683)\end{array}$ & $\begin{array}{l}0.535 \\
(2.69)\end{array}$ & $\begin{array}{c}1.548 \\
(1.441)\end{array}$ & $\begin{array}{l}1.542 \\
(1.44)\end{array}$ \\
\hline D89 & $\begin{array}{c}-0.054^{* *} \\
(0.025)\end{array}$ & $\begin{array}{l}-0.051^{\star \star} \\
(0.025)\end{array}$ & $\begin{array}{l}-0.056^{\star \star} \\
(0.025)\end{array}$ & $\begin{array}{l}-0.052^{\star *} \\
(0.025)\end{array}$ & $\begin{array}{l}-0.058^{* *} \\
(0.025)\end{array}$ & $\begin{array}{l}-0.054^{* *} \\
(0.025)\end{array}$ & $\begin{array}{l}-0.02 \\
(0.033)\end{array}$ & $\begin{array}{l}-0.015 \\
(0.033)\end{array}$ & $\begin{array}{l}-0.062 \\
(0.042)\end{array}$ & $\begin{array}{l}-0.065 \\
(0.042)\end{array}$ & $\begin{array}{l}-0.053^{*} \\
(0.031)\end{array}$ & $\begin{array}{l}-0.046 \\
(0.031)\end{array}$ \\
\hline solvency & $\begin{array}{c}0.01 \\
(0.035) \\
\end{array}$ & $\begin{array}{c}0.01 \\
(0.035) \\
\end{array}$ & $\begin{array}{c}0.004 \\
(0.035) \\
\end{array}$ & $\begin{array}{c}0.004 \\
(0.035) \\
\end{array}$ & $\begin{array}{c}0.007 \\
(0.035) \\
\end{array}$ & $\begin{array}{c}0.007 \\
(0.035) \\
\end{array}$ & $\begin{array}{c}0.061 \\
(0.047) \\
\end{array}$ & $\begin{array}{c}0.061 \\
(0.047) \\
\end{array}$ & $\begin{array}{l}0.117^{* *} \\
(0.059) \\
\end{array}$ & $\begin{array}{l}0.118^{* *} \\
(0.059) \\
\end{array}$ & $\begin{array}{c}-0.04 \\
(0.043) \\
\end{array}$ & $\begin{array}{c}-0.04 \\
(0.043) \\
\end{array}$ \\
\hline Observ. & 20462 & 20462 & 20114 & 20114 & 19975 & 19975 & 12549 & 12549 & 6374 & 6374 & 13747 & 13747 \\
\hline Firms & 5705 & 5705 & 5604 & 5604 & 5547 & 5547 & 4911 & 4911 & 1717 & 1717 & 3891 & 3891 \\
\hline Censored & 273 & 273 & 265 & 265 & 263 & 263 & 174 & 174 & 77 & 77 & 189 & 189 \\
\hline Log-MLE & $\begin{array}{l}-16407 \\
\end{array}$ & -16405 & -16135 & $\begin{array}{l}-16134 \\
\end{array}$ & -16053 & -16052 & -10237 & -10235 & -4486 & -4485 & -11537 & -11535 \\
\hline
\end{tabular}




\begin{tabular}{|c|c|c|c|c|c|c|c|c|c|c|c|c|}
\hline sigma & $\begin{array}{c}0.538 \\
(0.003)\end{array}$ & $\begin{array}{c}0.538 \\
(0.003)\end{array}$ & $\begin{array}{c}0.538 \\
(0.003)\end{array}$ & $\begin{array}{c}0.538 \\
(0.003)\end{array}$ & $\begin{array}{c}0.539 \\
(0.003)\end{array}$ & $\begin{array}{c}0.539 \\
(0.003)\end{array}$ & $\begin{array}{c}0.546 \\
(0.003)\end{array}$ & $\begin{array}{c}0.546 \\
(0.003)\end{array}$ & $\begin{array}{c}0.487 \\
(0.004)\end{array}$ & $\begin{array}{c}0.487 \\
(0.004)\end{array}$ & $\begin{array}{c}0.586 \\
(0.003)\end{array}$ & $\begin{array}{c}0.558 \\
(0.003)\end{array}$ \\
\hline Pseudo R^2 & 0.116 & 0.116 & 0.116 & 0.116 & 0.12 & 0.12 & 0.118 & 0.118 & 0.142 & 0.142 & 0.11 & 0.11 \\
\hline
\end{tabular}

Estimated coefficients reported, ${ }^{*}$ significant at $10 \% ;{ }^{* *}$ significant at $5 \% ;{ }^{* *}$ significant at $1 \%$.

\section{NOTES:}

a) All specifications include: constant, year, industry, regional dummies and cross effects of industry with trend.

b) In case of 4 industries when I observe the foreign entry during my sample period the entry growth rates are equal to 2 , according to an alternative formula for growth rates: $y(t+1)-y(t) /[y(t+1)+y(t)] / 2$.

c) R2 in random effects corresponds to overall variation, and in Tobit R2 stands for Pseudo R2.

(Pseudo $R^{\wedge} 2=1-L 1 / L 0$, where L1 is MLE of estimated model, L0 is MLE of "only constant" model.)

\section{SPECIFIC TEST RESULTS:}

1) $\mathrm{F}$ test does not reject $\mathrm{HO}$ : $\mathrm{FGcl}=\mathrm{FGncl}$ but rejects $\mathrm{HO}$ : STATICcl=STATICncl at $5 \%$.

2) Regional dummies jointly insignificant in all specifications.

3) Industry dummies jointly significant in all specifications.

4) Cross effects (industry $x$ trend) jointly significant in all specifications.

5) The results the same when exit dummies excluded.

6) All firm level means jointly significant in all specifications. 
Table 4.2: Exit and survival. Alternative specifications include firm level means to model unobserved heterogeneity.

\begin{tabular}{|c|c|c|c|c|c|c|c|c|c|c|}
\hline \multirow{3}{*}{$\begin{array}{l}\text { Sample } \\
\text { Model } \\
\end{array}$} & \multirow{2}{*}{\multicolumn{2}{|c|}{$\begin{array}{c}\text { I) exclude industries } \\
\text { without foreign presence }\end{array}$}} & \multirow{2}{*}{\multicolumn{2}{|c|}{$\begin{array}{l}\text { II) exclude I) and } \\
4 \text { entry industries }\end{array}$}} & \multirow{2}{*}{\multicolumn{2}{|c|}{$\begin{array}{l}\text { III) only positive } \\
\text { Foreign Growth }\end{array}$}} & \multicolumn{4}{|c|}{ IV) TECHNOLOGY } \\
\hline & & & & & & & \multicolumn{2}{|c|}{ LEADERS } & \multicolumn{2}{|c|}{ LAGGARDS } \\
\hline & Lognormal & Probit & Lognormal & Probit & Lognormal & Probit & Lognormal & Probit & Lognormal & Probit \\
\hline$\overline{\overline{\text { FGcl }}}$ & $\begin{array}{c}1.168^{\star \star *} \\
(0.038)\end{array}$ & $\begin{array}{c}-0.122^{* * \star} \\
(0.023)\end{array}$ & $\begin{array}{c}1.171^{* * *} \\
(0.038)\end{array}$ & $\begin{array}{c}-0.121^{* \star *} \\
(0.023)\end{array}$ & $\begin{array}{c}1.279^{* \star *} \\
(0.08)\end{array}$ & $\begin{array}{c}-0.238^{* * *} \\
(0.049)\end{array}$ & $\begin{array}{c}1.146^{* * *} \\
(0.04)\end{array}$ & $\begin{array}{c}-0.109^{\star \star *} \\
(0.025)\end{array}$ & $\begin{array}{l}1.261^{* *} \\
(0.144)\end{array}$ & $\begin{array}{l}-0.109^{*} \\
(0.061)\end{array}$ \\
\hline FGncl & $\begin{array}{c}1.619^{* * *} \\
(0.172)\end{array}$ & $\begin{array}{c}-0.307^{\star * *} \\
(0.057)\end{array}$ & $\begin{array}{c}1.625^{\star \star *} \\
(0.176)\end{array}$ & $\begin{array}{c}-0.305^{\star * *} \\
(0.056)\end{array}$ & $\begin{array}{c}2.613^{* * *} \\
(0.403)\end{array}$ & $\begin{array}{c}-0.625^{\star * *} \\
(0.11)\end{array}$ & $\begin{array}{c}1.747^{* * *} \\
(0.238)\end{array}$ & $\begin{array}{c}-0.344^{\star * *} \\
(0.08)\end{array}$ & $\begin{array}{l}1.814^{* *} \\
(0.511)\end{array}$ & $\begin{array}{l}-0.331^{*} \\
(0.201)\end{array}$ \\
\hline STATICcI & $\begin{array}{c}0.195^{\star * *} \\
(0.03)\end{array}$ & $\begin{array}{c}1.134^{* * *} \\
(0.095)\end{array}$ & $\begin{array}{c}0.190^{* * *} \\
(0.03)\end{array}$ & $\begin{array}{c}1.139^{* * *} \\
(0.096)\end{array}$ & $\begin{array}{c}0.186^{* * *} \\
(0.037)\end{array}$ & $\begin{array}{c}1.296^{* * *} \\
(0.13)\end{array}$ & $\begin{array}{c}0.262^{* * *} \\
(0.046)\end{array}$ & $\begin{array}{c}0.952^{* * *} \\
(0.124)\end{array}$ & $\begin{array}{c}0.200^{* * *} \\
(0.066)\end{array}$ & $\begin{array}{c}0.985^{\star * *} \\
(0.222)\end{array}$ \\
\hline STATICncl & $\begin{array}{c}0.105^{\star \star \star *} \\
(0.021)\end{array}$ & $\begin{array}{c}1.660^{\star * *} \\
(0.106)\end{array}$ & $\begin{array}{c}0.101^{* * *} \\
(0.02)\end{array}$ & $\begin{array}{c}1.670^{* \star *} \\
(0.107)\end{array}$ & $\begin{array}{c}0.094^{* * *} \\
(0.022)\end{array}$ & $\begin{array}{c}1.903^{* \star *} \\
(0.143)\end{array}$ & $\begin{array}{c}0.126^{* * *} \\
(0.028)\end{array}$ & $\begin{array}{c}1.549^{\star \star \star *} \\
(0.123)\end{array}$ & $\begin{array}{c}0.111^{\text {*** }} \\
(0.048)\end{array}$ & $\begin{array}{c}1.450^{\star \star *} \\
(0.264)\end{array}$ \\
\hline IndG & $\begin{array}{c}0.998 \\
(0.042)\end{array}$ & $\begin{array}{c}0.004 \\
(0.032)\end{array}$ & $\begin{array}{c}0.998 \\
(0.042)\end{array}$ & $\begin{array}{c}0.003 \\
(0.032)\end{array}$ & $\begin{array}{c}0.986 \\
(0.053)\end{array}$ & $\begin{array}{c}0.036 \\
(0.042)\end{array}$ & $\begin{array}{c}1.055 \\
(0.062)\end{array}$ & $\begin{array}{c}-0.042 \\
(0.047)\end{array}$ & $\begin{array}{c}0.901 \\
(0.075)\end{array}$ & $\begin{array}{l}0.070^{*} \\
(0.037)\end{array}$ \\
\hline ageT & & $\begin{array}{l}0.117^{\star *} \\
(0.048)\end{array}$ & & $\begin{array}{l}0.110^{* *} \\
(0.048)\end{array}$ & & $\begin{array}{c}0.164^{* \star *} \\
(0.063)\end{array}$ & & $\begin{array}{c}0.193^{\star * *} \\
(0.06)\end{array}$ & & $\begin{array}{l}-0.052 \\
(0.077)\end{array}$ \\
\hline ageT2 & & $\begin{array}{c}-0.009^{\star *} \\
(0.004)\end{array}$ & & $\begin{array}{c}-0.009^{* *} \\
(0.004)\end{array}$ & & $\begin{array}{c}-0.014^{* *} \\
(0.006)\end{array}$ & & $\begin{array}{c}-0.017^{* * *} \\
(0.005)\end{array}$ & & $\begin{array}{c}0.007 \\
(0.007)\end{array}$ \\
\hline sales & $\begin{array}{c}25.648^{* * *} \\
(28.963)\end{array}$ & $\begin{array}{c}-3.309^{* * *} \\
(1.15)\end{array}$ & $\begin{array}{l}30.292^{* * *} \\
(35.746)\end{array}$ & $\begin{array}{l}-3.390^{* * *} \\
(1.176)\end{array}$ & $\begin{array}{l}14.334^{*} \\
(21.32)\end{array}$ & $\begin{array}{l}-2.602 \\
(1.643)\end{array}$ & $\begin{array}{c}54.462^{* \star *} \\
(78.746)\end{array}$ & $\begin{array}{c}-4.423^{* * *} \\
(1.657)\end{array}$ & $\begin{array}{l}5.795 \\
(11.5)\end{array}$ & $\begin{array}{l}-1.891 \\
(1.521)\end{array}$ \\
\hline sales2 & $\begin{array}{c}0.469^{* * *} \\
(0.111)\end{array}$ & $\begin{array}{c}0.742^{* * *} \\
(0.223)\end{array}$ & $\begin{array}{c}0.466^{* \star *} \\
(0.106)\end{array}$ & $\begin{array}{c}0.736^{* \star *} \\
(0.219)\end{array}$ & $\begin{array}{l}0.477^{* *} \\
(0.172)\end{array}$ & $\begin{array}{l}0.718^{\star *} \\
(0.306)\end{array}$ & $\begin{array}{l}0.347^{* *} \\
(0.148)\end{array}$ & $\begin{array}{c}1.045^{\star \star *} \\
(0.371)\end{array}$ & $\begin{array}{c}0.478 \\
(0.255)\end{array}$ & $\begin{array}{l}0.764^{*} \\
(0.415)\end{array}$ \\
\hline AS & & $\begin{array}{c}0.022 \\
(0.115)\end{array}$ & & $\begin{array}{c}0.026 \\
(0.118)\end{array}$ & & $\begin{array}{l}-0.062 \\
(0.147)\end{array}$ & & $\begin{array}{c}0.087 \\
(0.172)\end{array}$ & & $\begin{array}{l}-0.034 \\
(0.118)\end{array}$ \\
\hline ES & $\begin{array}{l}3.194^{*} \\
(2.102)\end{array}$ & $\begin{array}{c}-1.132^{* *} \\
(0.545)\end{array}$ & $\begin{array}{l}3.208^{*} \\
(2.143)\end{array}$ & $\begin{array}{c}-1.130^{* *} \\
(0.546)\end{array}$ & $\begin{array}{c}2.242 \\
(1.766)\end{array}$ & $\begin{array}{l}-0.927 \\
(0.778)\end{array}$ & $\begin{array}{l}3.747^{*} \\
(2.763)\end{array}$ & $\begin{array}{l}-1.273^{*} \\
(0.663)\end{array}$ & $\begin{array}{c}3.375 \\
(4.671)\end{array}$ & $\begin{array}{l}-0.569 \\
(0.885)\end{array}$ \\
\hline FORdirect & $\begin{array}{c}0.991 \\
(0.008)\end{array}$ & $\begin{array}{c}0.005 \\
(0.007)\end{array}$ & $\begin{array}{c}0.991 \\
(0.009)\end{array}$ & $\begin{array}{c}0.005 \\
(0.007)\end{array}$ & $\begin{array}{l}0.989 \\
(0.01)\end{array}$ & $\begin{array}{c}0.007 \\
(0.009)\end{array}$ & $\begin{array}{c}0.985 \\
(0.009)\end{array}$ & $\begin{array}{c}0.011 \\
'(0.008)\end{array}$ & $\begin{array}{c}1.006 \\
(0.007)\end{array}$ & $\begin{array}{l}-0.005 \\
(0.004)\end{array}$ \\
\hline intang & $\begin{array}{c}0.015 \\
(0.048)\end{array}$ & $\begin{array}{c}3.643 \\
(2.802)\end{array}$ & $\begin{array}{c}0.02 \\
(0.062)\end{array}$ & $\begin{array}{c}3.519 \\
(2.745)\end{array}$ & $\begin{array}{c}0.244 \\
(0.654)\end{array}$ & $\begin{array}{c}2.351 \\
(2.693)\end{array}$ & $\begin{array}{c}39.091 \\
(379)\end{array}$ & $\begin{array}{c}3.624 \\
(8.082)\end{array}$ & $\begin{array}{c}0.159 \\
(2.392)\end{array}$ & $\begin{array}{c}2.877 \\
(11.397)\end{array}$ \\
\hline gap & $\begin{array}{c}3.019 \\
(10.454)\end{array}$ & $\begin{array}{l}-0.318 \\
(2.91)\end{array}$ & $\begin{array}{l}2.008 \\
(6.842)\end{array}$ & $\begin{array}{l}-0.118 \\
(2.857)\end{array}$ & $\begin{array}{c}0.048 \\
(0.151)\end{array}$ & $\begin{array}{c}2.019 \\
(2.973)\end{array}$ & $\begin{array}{c}0.001 \\
(0.009)\end{array}$ & $\begin{array}{l}-0.081 \\
(8.344)\end{array}$ & $\begin{array}{l}3961 \mathrm{~d}) \\
(39627)\end{array}$ & $\begin{array}{l}-7.325 \\
(7.398)\end{array}$ \\
\hline ESgap & $\begin{array}{l}154 \mathrm{~d}) \\
(1399)\end{array}$ & $\begin{array}{l}-10.162 \\
(8.313)\end{array}$ & $\begin{array}{l}240 \mathrm{~d}) \\
(2214)\end{array}$ & $\begin{array}{l}-10.361 \\
(8.326)\end{array}$ & $\begin{array}{c}\left.50589130^{* *} \mathrm{~d}\right) \\
(504593)\end{array}$ & $\begin{array}{c}-22.791^{* *} \\
(8.897)\end{array}$ & $\begin{array}{l}576 \text { d) } \\
(5331)\end{array}$ & $\begin{array}{l}-11.721 \\
(8.423)\end{array}$ & $\begin{array}{c}7528 \mathrm{~d}) \\
(293)\end{array}$ & $\begin{array}{l}-12.397 \\
(29.521)\end{array}$ \\
\hline D89 & $\begin{array}{c}2.156^{* \star *} \\
(0.423)\end{array}$ & $\begin{array}{l}-0.233 \\
(0.169)\end{array}$ & $\begin{array}{c}2.136^{\star * *} \\
(0.429\end{array}$ & $\begin{array}{l}-0.223 \\
(0.171)\end{array}$ & $\begin{array}{c}1.954^{\star * * *} \\
(0.412)\end{array}$ & $\begin{array}{l}-0.173 \\
(0.204)\end{array}$ & $\begin{array}{c}1.774^{* * *} \\
(0.354)\end{array}$ & $\begin{array}{l}-0.003 \\
(0.182)\end{array}$ & $\begin{array}{c}3.557^{* * *} \\
(1.303)\end{array}$ & $\begin{array}{c}-0.802^{* * *} \\
(0.285)\end{array}$ \\
\hline solvency & $\begin{array}{c}5.857^{* \star *} \\
(1.872)\end{array}$ & $\begin{array}{c}-1.298^{* * *} \\
(0.194)\end{array}$ & $\begin{array}{c}7.069^{* * *} \\
(2.158)\end{array}$ & $\begin{array}{c}-1.376^{\star \star *} \\
(0.184)\end{array}$ & $\begin{array}{c}5.546^{\star * *} \\
(2.045)\end{array}$ & $\begin{array}{c}-1.454^{\star \star *} \\
(0.293)\end{array}$ & $\begin{array}{c}4.194^{* \star *} \\
(1.503)\end{array}$ & $\begin{array}{c}-1.118^{\star \star \star} \\
(0.235)\end{array}$ & $\begin{array}{c}15.386^{\star \star *} \\
(8.909)\end{array}$ & $\begin{array}{c}-1.711^{* \star *} \\
(0.305)\end{array}$ \\
\hline Observ. & 24317 & 24317 & 23884 & 23884 & 13886 & 13886 & 16694 & 16694 & 7631 & 7631 \\
\hline Firms & 6177 & 6177 & 6049 & 6049 & 5409 & 5409 & 4308 & 4308 & 1873 & 1873 \\
\hline Exits & 265 & 265 & 262 & 262 & 174 & 174 & 189 & 189 & 77 & 77 \\
\hline$\overline{M L E}$ & -722 & -1146 & -709 & -1128 & -0.426 & -693 & -497.5 & -805 & -236 & -353 \\
\hline Pseudo R2 & & 0.22 & & 0.22 & & 0.26 & & 0.22 & & 0.18 \\
\hline In_sigma & $\begin{array}{l}-0.051 \\
(0.068) \\
\end{array}$ & & $\begin{array}{l}-0.043 \\
(0.069)\end{array}$ & & $\begin{array}{c}-0.169^{\star *} \\
(0.081)\end{array}$ & & $\begin{array}{l}-0.081 \\
(0.087)\end{array}$ & & $\begin{array}{l}0.071 \\
(0.11)\end{array}$ & \\
\hline
\end{tabular}




\section{NOTES:}

a) All specifications include: annual re-grouped dummies, industry re-grouped dummies, regional dummies.

b) In Lognormal model reported results represent exponentiated coefficients $\exp \{b e t a\}$.

c) In Probit model the coefficients are reported, marginal effects of the coefficients of interest are in the main text.

d) For presentation purposes exponentiated coefficients and standard errors divided by 1000 .

e) Standard errors of exponentiated coefficients are calculated by Delta method.

However, Wald test results for significance of individual coefficients are based on natural regression coefficients, because of skewed distribution of ratios.

f) Firm level means to control for unobserved heterogeneity exclude: all dummies, STATIC, D89 and IndG.

In probit specifications means of: ageT, ageT2 and AS are also excluded, because these means are not used in survival analysis.

\section{SPECIFIC TEST RESULTS:}

1) Firm level means jointly significant in all specifications.

2) Industry dummies jointly significant at $5 \%$ and regional dummies significant at $10 \%$ in all specifications.

3) F test rejects HO: STATICCl=STATICncl at $5 \%$ in all lognormal specifications with the exception of technology laggards. (There $\mathrm{H} 0$ rejected at $10 \%$ )

$\mathrm{F}$ test rejects $\mathrm{H} 0: \mathrm{FGcl}=\mathrm{FGncl}$ at $5 \%$ in all lognormal specifications besides: technology laggards.

4) When clusters on industry-year specified the coefficients of FG and STATIC remain significant at least at $5 \%$ in all specifications. 


\section{Appendix C:}

Table C1:Liquidation and bankruptcy process - START/END

Liquidation process:

\begin{tabular}{|c|c|c|c|c|c|}
\hline \multirow[t]{2}{*}{ Year } & \multicolumn{2}{|c|}{ START } & \multicolumn{2}{|l|}{ END } & \multirow[b]{2}{*}{$\%$} \\
\hline & \# of firms & $\%$ & Year & \# of firms & \\
\hline not known & 97 & 23.26 & not known & 97 & 23.26 \\
\hline 1994 & 2 & 0.48 & 1994 & no & \\
\hline 1995 & 5 & 1.2 & 1995 & no & \\
\hline 1996 & 1 & 0.24 & 1996 & no & \\
\hline 1997 & 16 & 3.84 & 1997 & 1 & 0.24 \\
\hline 1998 & 56 & 13.43 & 1998 & no & \\
\hline 1999 & 60 & 14.39 & 1999 & no & \\
\hline 2000 & 68 & 16.31 & 2000 & 1 & 0.24 \\
\hline 2001 & 51 & 12.23 & 2001 & 2 & 0.48 \\
\hline 2002 & 56 & 13.43 & 2002 & 3 & 0.72 \\
\hline 2003 & 5 & 1.2 & continues & 313 & 75.06 \\
\hline Total & 417 & 100 & Total & 417 & 100 \\
\hline
\end{tabular}

Notes: "not known" means it must be after 2000, because these are the firms with the name "v likvidaci", which have the last balance sheet filed with Amadeus in year 2000 or later.

Bankruptcy process:

\begin{tabular}{|c|c|c|c|c|c|}
\hline \multirow[t]{2}{*}{ Year } & \multicolumn{2}{|c|}{ START } & \multicolumn{3}{|l|}{ END } \\
\hline & \# of firms & $\%$ & Year & \# of firms & $\%$ \\
\hline 1995 & 1 & 0.18 & 1995 & 1 & 0.18 \\
\hline 1996 & 1 & 0.18 & 1996 & no & no \\
\hline 1997 & 13 & 2.38 & 1997 & no & no \\
\hline 1998 & 56 & 10.26 & 1998 & 2 & 0.37 \\
\hline 1999 & 96 & 17.58 & 1999 & 3 & 0.55 \\
\hline 2000 & 147 & 26.92 & 2000 & 6 & 1.1 \\
\hline 2001 & 142 & 26.01 & 2001 & 12 & 2.2 \\
\hline 2002 & 83 & 15.2 & 2002 & 31 & 5.68 \\
\hline 2003 & 7 & 1.28 & Jan-Mar2003 & 6 & 1.1 \\
\hline & & & continues & 485 & 88.83 \\
\hline Total & 546 & 100 & Total & 546 & 100 \\
\hline
\end{tabular}

Notes:

the start of liquidation process: 0 firms

the start of bankruptcy process: 3 firms

\section{Source:}

The information on the beginning and end of liquidation/bankruptcy processes shown in table were obtained from the Office of Business Registrar at the Department of Justice of the Czech Republic.

According to the law for the Czech Statistical Office, the firm registration information

(without balance sheet information) is publicly available at the webpage: www.justice.cz. 


\section{Table C2: Performance Comparison - classified vs. non-classified firms (NCL=1) over period: 1994-2001.}

\begin{tabular}{|c|c|c|c|c|}
\hline \multirow[b]{2}{*}{ Variable } & \multirow{2}{*}{$\begin{array}{c}\text { Classified } \\
\text { mean }\end{array}$} & \multirow{2}{*}{$\begin{array}{l}\text { Difference in means } \\
\text { NCL -classified firms }\end{array}$} & \multicolumn{2}{|c|}{ No of observations } \\
\hline & & & classified & NCL-firms \\
\hline & (const) & $(\mathrm{NCL}=1)$ & & \\
\hline \# of firms & $148.7^{* * *}$ & $20.5^{\star *}$ & 43186 & 18252 \\
\hline growth rate & $0.113^{* *}$ & $-0.051^{* *}$ & 21209 & 5830 \\
\hline market share & $0.049^{* *}$ & $-0.011^{\star *}$ & 26759 & 7795 \\
\hline market share (US2) & $0.013^{* *}$ & $-0.003^{* * *}$ & 26759 & 7795 \\
\hline employment & $292^{* *}$ & $-90.4^{* *}$ & 25831 & 7588 \\
\hline operating revenue & $16541^{* *}$ & $-7521^{* \star}$ & 26673 & 7810 \\
\hline$K / L$ & $105.2^{* *}$ & $38^{* *}$ & 25611 & 7537 \\
\hline intangible assets & $142.9^{*}$ & $-60.9^{*}$ & 27379 & 8050 \\
\hline total assets & $18008^{* *}$ & $-4791^{\star *}$ & 27433 & 8093 \\
\hline intangible ratio & $0.008^{* *}$ & 0.001 & 27379 & 8050 \\
\hline sales & $0.157^{\star *}$ & $-0.076^{* *}$ & 26759 & 7795 \\
\hline value added & $6858^{* *}$ & $-1862^{* *}$ & 25946 & 7089 \\
\hline return on assets & $1.89^{* *}$ & $0.226^{\star * *}$ & 26958 & 7942 \\
\hline liquidity ratio & $1.7^{\star *}$ & -0.053 & 27101 & 7995 \\
\hline solvency ratio & $0.383^{* *}$ & $0.033^{* * *}$ & 27433 & 8093 \\
\hline profit margin & 0.133 & 0.053 & 25974 & 7558 \\
\hline
\end{tabular}

** significant at 5\%, * significant at $10 \%$

Notes:

classified firms $=1398$ foreign firms +5235 domestic firms non-classified firms (without ownership information) $=3353$ firms

\section{Variables are:}

growth rate $=$ growth rate in sales revenues between $(\mathrm{t}+1)$ and $\mathrm{t}$ market share $=$ firm market share at 3-digit primary US SIC market share $(\mathrm{US} 2)=$ firm market share at 2-digit primary US SIC employment=number of firm employees operating revenue $=$ operating revenue (turnover) in 1000 USD $\mathrm{K} / \mathrm{L}$ ratio $=$ fixed assets $/$ employment intangible assets in 1000 of USD total assets $=$ total firm assets in 1000 of USD intangible ass. ratio $=$ intangible/total assets sales in 100 millions of USD value added $=$ taxation profit(loss) per year + costs of employees

$$
+ \text { depreciation }+ \text { interest paid }
$$

liquidity ratio $=($ current assets - stocks $) /$ current liabilities return on assets $(\%)=[$ Profit $($ loss $)$ before taxation/total assets $] * 100$ solvency ratio $=$ shareholders funds(including reserves)/total assets profit margin in $(\%)=[[($ operating revenue - costs of good sold - other operating expenditures $)+$ (financial revenue -financial expenses)]/operating revenue ]*100 
Table C3: Size and profitability of firms founded before start of transition in 1989 (D89=1) and after transition started (D89=0). Sample period: 1994-2001.

\begin{tabular}{|c|c|c|c|c|}
\hline \multirow{2}{*}{$\begin{array}{l}\text { sample } \\
\qquad \text { variable } \\
\text { (st. error) [\# of observ] }\end{array}$} & \multicolumn{2}{|c|}{ growth sample (20462 obs.) } & \multicolumn{2}{|c|}{ exit sample (24733 obs.) } \\
\hline & $\begin{array}{r}\text { D89=1 } \\
{[1141]}\end{array}$ & $\begin{array}{l}\mathbf{D} 89=0 \\
{[19321]}\end{array}$ & $\begin{array}{l}\text { D89=1 } \\
{[1299]}\end{array}$ & $\begin{array}{l}\mathbf{D} 89=0 \\
{[23434]}\end{array}$ \\
\hline growth rate & $\begin{array}{l}-0.013 \\
(0.392)[1141]\end{array}$ & $\begin{array}{l}0.1 \\
(0.6)[19321]\end{array}$ & $\begin{array}{l}-0.013 \\
(0.392)[1141]\end{array}$ & $\begin{array}{l}0.1 \\
(0.6)[19321]\end{array}$ \\
\hline total assets & $\begin{array}{l}20578 \\
(39298) \text { [1141] }\end{array}$ & $\begin{array}{l}12822 \\
(112409)[19321]\end{array}$ & $\begin{array}{l}20039.5 \\
(38091.5) \text { [1299] }\end{array}$ & $\begin{array}{l}11699 \\
-103496\end{array}$ \\
\hline employment (L) & $\begin{array}{l}310.5 \\
(404.5) \text { [1135] }\end{array}$ & $\begin{array}{l}230.5 \\
(656)[18375]\end{array}$ & $\begin{array}{l}301 \\
(393)[1291]\end{array}$ & $\begin{array}{l}219 \\
(636) \text { [22208] }\end{array}$ \\
\hline fixed assets (K) & $\begin{array}{l}12835 \\
(20623)[1126]\end{array}$ & $\begin{array}{l}7763 \\
(91848) \text { [19135] }\end{array}$ & $\begin{array}{l}12637 \\
(20737)[1284]\end{array}$ & $\begin{array}{l}7037 \\
(84721) \text { [23248] }\end{array}$ \\
\hline K/L & $\begin{array}{l}235.7 \\
(952)[1120]\end{array}$ & $\begin{array}{l}85.7 \\
(453.7)[18204]\end{array}$ & $\begin{array}{l}247.2 \\
(1083.4)[1276]\end{array}$ & $\begin{array}{l}84.9 \\
(458.9) \text { [22037] }\end{array}$ \\
\hline operating revenue & $\begin{array}{l}10429.6 \\
(19208)[1126]\end{array}$ & $\begin{array}{l}11242 \\
(51997)[19126]\end{array}$ & $\begin{array}{l}10955 \\
(32376)[1284]\end{array}$ & $\begin{array}{l}10486 \\
(48158) \text { [23239] }\end{array}$ \\
\hline operating profit & $\begin{array}{l}71.2 \\
(2441.3) \text { [1126] }\end{array}$ & $\begin{array}{l}433.05 \\
(8339)[19135]\end{array}$ & $\begin{array}{l}88.9 \\
(2395)[1284]\end{array}$ & $\begin{array}{l}384.3 \\
(7597.3) \text { [23248] }\end{array}$ \\
\hline gross profit & $\begin{array}{l}1126.7 \\
(2596)[1126]\end{array}$ & $\begin{array}{l}1383.46 \\
(12362)[19126]\end{array}$ & $\begin{array}{l}1208.3 \\
(3450)[1284]\end{array}$ & $\begin{array}{l}1281 \\
(11308) \text { [23238] }\end{array}$ \\
\hline
\end{tabular}

\section{Notes:}

gross profit =operating revenues - costs of goods sold, and operating profit $=$ gross profit-other operating expenses. 
Table C4: List of 142 industries with at least 10 domestic firms during: 1994-2001. (including 11 industries without foreign presence)

\begin{tabular}{|c|c|c|c|c|c|}
\hline $\begin{array}{c}142 \\
\text { 3-digit } \\
\text { US SIC } \\
\text { industry }\end{array}$ & $\begin{array}{l}\text { Industry description (below): } \\
\text { Out of } 142 \text { industries analyzed: } \\
\text { Technology difference between domestic and foreign firms: } \\
>0 \text { (domestic firms technology leaders, } 83 \text { industries) } \\
=0 \text { (the same technology, } 0 \text { industries) } \\
<0 \text { (domestic firms technology laggards, } 47 \text { industries) } \\
\text { (missing foreign intangible asset ratio) = } 1 \text { industry } \\
11 \text { industries are without foreign presence }\end{array}$ & $\begin{array}{c}\text { Number of } \\
\text { domestic firms } \\
\text { in the industry } \\
\text { per sample } \\
\text { period } \\
\text { 1994-2001 } \\
\text { (before } \\
\text { cleaning) }\end{array}$ & $\begin{array}{l}\text { Average } \\
\text { number of } \\
\text { foreign firms } \\
\text { per industry } \\
\text { and year } \\
\text { 1994-2001 } \\
\text { (before } \\
\text { cleaning) }\end{array}$ & $\begin{array}{l}\text { Technology } \\
\text { difference } \\
\text { between } \\
\text { domestic \& } \\
\text { foreign } \\
\text { (industry } \\
\text { means } \\
\text { over time) }\end{array}$ & $\begin{array}{c}\text { Intangible } \\
\text { asset ratio } \\
\text { of foreign firms } \\
\text { (industry } \\
\text { means } \\
\text { over time) }\end{array}$ \\
\hline 152 & general building and residential building contractors & 318 & 14.9 & -0.0016 & 0.0040 \\
\hline 161 & highway and street construction & 33 & 15.4 & -0.0031 & 0.0057 \\
\hline 162 & heavy construction & 88 & 3.1 & 0.0017 & 0.0015 \\
\hline 171 & plumbing, heating and air-conditioning & 37 & 2.0 & 0.0038 & 0.0007 \\
\hline 172 & painting and paper hanging & 11 & 0.0 & NA & NA \\
\hline 173 & electrical work & 54 & 1.9 & 0.0083 & 0.0009 \\
\hline 174 & masonry, stonework, title setting and plastering & 26 & 1.0 & 0.0005 & 0.0000 \\
\hline 175 & carpentry and floor work & 11 & 0.0 & NA & NA \\
\hline 179 & miscellaneous special trade contractors & 86 & 5.0 & 0.0012 & 0.0009 \\
\hline 201 & meat products & 71 & 3.6 & 0.0073 & 0.0033 \\
\hline 202 & dairy products & 58 & 8.6 & 0.0075 & 0.0007 \\
\hline 203 & canned, frozen and preserved fruits, vegetables and food specialties manuf. & 42 & 6.8 & -0.0068 & 0.0085 \\
\hline 204 & grain mill products & 88 & 4.4 & -0.0029 & 0.0049 \\
\hline 205 & bakery products manuf. & 63 & 3.8 & 0.0037 & 0.0077 \\
\hline 206 & sugar and confectionary products & 10 & 4.3 & -0.0010 & 0.0038 \\
\hline 208 & beverages & 88 & 8.9 & -0.0002 & 0.0048 \\
\hline 209 & miscellaneous food preparations and kindred products & 12 & 5.9 & 0.0055 & 0.0069 \\
\hline 221 & broad woven fabric mills & 13 & 2.0 & 0.0009 & 0.0003 \\
\hline 225 & knitting mills manuf. & 25 & 4.5 & -0.0060 & 0.0114 \\
\hline 228 & yarn and thread mills manuf. & 26 & 4.3 & -0.0032 & 0.0053 \\
\hline 229 & miscellaneous textile goods manuf. & 24 & 4.0 & -0.0004 & 0.0027 \\
\hline 232 & men's and boy's furnishings, work clothing & 19 & 1.0 & 0.0123 & 0.0002 \\
\hline 239 & miscellaneous fabricated textile products & 17 & 0.8 & -0.0060 & 0.0061 \\
\hline 242 & sawmills and planning mills & 62 & 10.9 & 0.0008 & 0.0016 \\
\hline 243 & millwork, veneer, plywood and structural wood members & 41 & 3.0 & 0.0068 & 0.0020 \\
\hline 244 & wood containers & 11 & 1.0 & 0.0004 & 0.0000 \\
\hline
\end{tabular}




\begin{tabular}{|c|c|}
\hline 251 & household furniture manuf. \\
\hline 252 & office furniture manuf. \\
\hline 265 & paperboard containers and boxes manuf. \\
\hline 267 & converted paper and paperboard products \\
\hline 271 & newspapers publishing \\
\hline 273 & books \\
\hline 275 & commercial printing \\
\hline 281 & industrial inorganic chemical manuf. \\
\hline 283 & drugs \\
\hline 284 & soap, detergents and cleaning preparations, perfumes, cosmetics \\
\hline 285 & paints, varnishes, lacquers, enamels \\
\hline 289 & miscellaneous chemical products manuf. \\
\hline 302 & rubber and plastic footwear manuf. \\
\hline 308 & miscellaneous plastic product manuf. \\
\hline 317 & handbags and other personal leather \\
\hline 322 & glass and glassware \\
\hline 325 & structural clay products manufacturing \\
\hline 326 & pottery and related products manuf. \\
\hline 327 & concrete, gypsum and plaster products manuf. \\
\hline 328 & cut stone and stone products manuf. \\
\hline 331 & still works, blast furnaces and rolling and fishing manuf. \\
\hline 332 & iron and steel foundries \\
\hline 333 & primary smelting and refining of nonferrous metals \\
\hline 339 & miscellaneous primary metal products \\
\hline 341 & metal cans and shipping containers \\
\hline 342 & cutlery, hand tools and general hardware \\
\hline 343 & heating equipments, except electric and warm air \\
\hline 344 & fabricated structural metal products \\
\hline 345 & screw machine products, bolts, nuts, screws rivets and washers \\
\hline 346 & metal forging and stamping \\
\hline 347 & coating, engraving and allied services \\
\hline 349 & miscellaneous fabricated metal products \\
\hline 351 & engines and turbines \\
\hline 352 & farm and garden machinery \\
\hline 353 & construction, mining and materials handling machinery and equipment \\
\hline 354 & metal working machinery and equipment \\
\hline 355 & special industry machinery \\
\hline
\end{tabular}

\begin{tabular}{|c|c|c|c|}
\hline 41 & 6.9 & -0.0041 & 0.0119 \\
\hline 12 & 0.0 & NA & NA \\
\hline 13 & 8.6 & -0.0022 & 0.0061 \\
\hline 20 & 1.0 & 0.0006 & 0.0004 \\
\hline 15 & 1.9 & -0.0272 & 0.0327 \\
\hline 13 & 2.0 & 0.0007 & 0.0141 \\
\hline 27 & 2.0 & 0.0033 & 0.0010 \\
\hline 11 & 4.4 & 0.0061 & 0.0015 \\
\hline 15 & 3.0 & -0.1125 & 0.1388 \\
\hline 35 & 4.6 & 0.0043 & 0.0018 \\
\hline 11 & 1.0 & 0.0002 & 0.0091 \\
\hline 11 & 0.3 & -0.0660 & 0.0236 \\
\hline 12 & 3.0 & 0.0041 & 0.0006 \\
\hline 81 & 21.9 & 0.0004 & 0.0092 \\
\hline 10 & 1.0 & 0.0026 & 0.0000 \\
\hline 21 & 9.4 & 0.0015 & 0.0016 \\
\hline 26 & 14.6 & 0.0112 & 0.0070 \\
\hline 10 & 7.0 & -0.0037 & 0.0075 \\
\hline 37 & 25.8 & 0.0085 & 0.0021 \\
\hline 11 & 5.3 & -0.0013 & 0.0032 \\
\hline 24 & 4.8 & 0.0059 & 0.0056 \\
\hline 32 & 0.0 & NA & NA \\
\hline 12 & 2.0 & -0.0005 & 0.0059 \\
\hline 14 & 5.0 & 0.0073 & 0.0004 \\
\hline 25 & 4.9 & -0.0050 & 0.0127 \\
\hline 57 & 6.8 & 0.0044 & 0.0058 \\
\hline 33 & 0.7 & -0.0054 & 0.0080 \\
\hline 132 & 11.9 & 0.0005 & 0.0030 \\
\hline 11 & 2.0 & 0.0056 & 0.0000 \\
\hline 58 & 7.6 & -0.0067 & 0.0108 \\
\hline 11 & 0.0 & NA & NA \\
\hline 51 & 19.3 & -0.0010 & 0.0095 \\
\hline 24 & 0.0 & NA & NA \\
\hline 24 & 1.9 & 0.0042 & 0.0021 \\
\hline 62 & 9.0 & -0.0023 & 0.0132 \\
\hline 55 & 5.4 & 0.0021 & 0.0085 \\
\hline 75 & 12.8 & -0.0156 & 0.0277 \\
\hline
\end{tabular}




\begin{tabular}{|l|l}
356 & general industrial machinery and equipment \\
359 & miscellaneous industrial and commercial machinery equip. \\
361 & electric transmission and distribution equipment \\
362 & electrical industrial apparatus \\
363 & household appliances \\
364 & electric lighting and wiring equipment \\
365 & household audio and video equipment \\
366 & communication equipment \\
367 & electronic components and accessories \\
371 & motor vehicles and motor vehicles manuf. \\
372 & printed circuit boards \\
374 & railroad equipment manuf. \\
375 & motorcycles, bicycles and parts manuf. \\
382 & laboratory apparatus and furniture manuf. \\
384 & surgical, medical and dental instruments a supplies \\
391 & jewelry, silverware and plated ware \\
394 & dolls, toys, games \\
395 & pens, pencils and other artists' materials \\
399 & miscellaneous manuf. Industries \\
414 & bus charter service \\
421 & trucking and courier services, except air \\
422 & public warehousing and storage \\
472 & arrangement of passenger transportation \\
481 & telephone communications \\
491 & electric services \\
493 & combination electric, gas and other utilities services \\
494 & water supply \\
495 & sanitary services \\
501 & motor vehicles and motor vehicle parts \\
502 & furniture and home furnishing wholesale dealing in \\
503 & lumber and other construction materials \\
504 & professional, commercial equipment \\
505 & metals and minerals, except petroleum wholesale dealing \\
506 & electrical goods wholesale dealing in \\
507 & hardware, plumbing and heating equipment \\
508 & machinery equipment and supplies wholesale dealing \\
509 & miscellaneous durable goods wholesale dealing \\
&
\end{tabular}




\begin{tabular}{|l|l}
512 & drugs, drug properties \\
513 & apparel, pieces goods and notions wholesales dealing in \\
514 & groceries and related products wholesale dealing \\
515 & farm product raw materials \\
516 & chemical and allied products \\
519 & miscellaneous non-durable goods \\
523 & paint, glass, and wallpaper stores \\
531 & department stores \\
541 & grocery stores \\
554 & gasoline service stations \\
571 & home furniture and furnishing stores \\
572 & household appliance stores \\
581 & eating and drinking places \\
591 & drug and proprietary stores \\
593 & used merchandise stores \\
594 & miscellaneous shopping goods stores \\
596 & no store retailers \\
614 & personal credit institutions \\
615 & business credit institutions \\
621 & security brokers, dealers, and flotation companies \\
628 & services allied with the exchange of securities and commodities \\
651 & real estate operators and lessons \\
653 & real estate agent and managers \\
671 & holding offices \\
672 & investment offices \\
679 & miscellaneous investing \\
701 & hotels and motels \\
721 & laundry, cleaning, garment services \\
729 & miscellaneous personal services \\
731 & advertising \\
734 & services to dwellings \\
735 & miscellaneous equipment rental and leasing \\
737 & computer programming, data processing, other PC serve. \\
738 & miscellaneous business service \\
751 & automotive rental and leasing \\
753 & automotive repair shops \\
792 & theatrical producers, bands orchestras, and entertainers \\
&
\end{tabular}

\begin{tabular}{|c|c|c|c|}
\hline 51 & 18.5 & 0.0012 & 0.0027 \\
\hline 36 & 3.9 & 0.0011 & 0.0040 \\
\hline 131 & 17.5 & 0.0028 & 0.0017 \\
\hline 51 & 3.0 & -0.0005 & 0.0017 \\
\hline 58 & 17.1 & -0.0012 & 0.0049 \\
\hline 34 & 13.6 & 0.0040 & 0.0043 \\
\hline 13 & 1.0 & 0.0072 & 0.0004 \\
\hline 119 & 18.3 & -0.0084 & 0.0117 \\
\hline 131 & 10.4 & -0.0003 & 0.0018 \\
\hline 43 & 3.9 & -0.0042 & 0.0051 \\
\hline 13 & 1.0 & 0.0004 & 0.0005 \\
\hline 13 & 1.0 & $\mathrm{NA}$ & NA \\
\hline 43 & 2.0 & 0.0064 & 0.0027 \\
\hline 26 & 3.0 & -0.0054 & 0.0135 \\
\hline 10 & 1.0 & 0.0121 & 0.0017 \\
\hline 157 & 15.5 & 0.0015 & 0.0050 \\
\hline 13 & 9.0 & 0.0032 & 0.0126 \\
\hline 58 & 16.3 & 0.0053 & 0.0011 \\
\hline 106 & 13.8 & 0.0025 & 0.0022 \\
\hline 39 & 9.6 & -0.0001 & 0.0056 \\
\hline 19 & 0.0 & NA & NA \\
\hline 454 & 41.4 & 0.0022 & 0.0014 \\
\hline 99 & 14.8 & 0.0091 & 0.0001 \\
\hline 20 & 2.0 & 0.0008 & 0.0064 \\
\hline 37 & 0.0 & NA & NA \\
\hline 129 & 13.8 & -0.0053 & 0.0118 \\
\hline 64 & 14.9 & 0.0032 & 0.0030 \\
\hline 11 & 1.8 & -0.0008 & 0.0111 \\
\hline 48 & 1.0 & 0.0100 & 0.0116 \\
\hline 105 & 15.0 & 0.0042 & 0.0040 \\
\hline 18 & 3.0 & -0.0048 & 0.0057 \\
\hline 15 & 2.9 & 0.0030 & 0.0002 \\
\hline 198 & 23.8 & 0.0312 & 0.0170 \\
\hline 89 & 6.0 & 0.0066 & 0.0061 \\
\hline 33 & 3.5 & 0.0105 & 0.0016 \\
\hline 203 & 2.8 & 0.0027 & 0.0009 \\
\hline 10 & 0.0 & NA & NA \\
\hline
\end{tabular}




\begin{tabular}{|c|c|c|c|c|c|}
\hline 794 & commercial sports & 20 & 1.6 & -0.1051 & 0.1037 \\
\hline 799 & miscellaneous amusement and creation services & 31 & 3.0 & 0.0139 & 0.0005 \\
\hline 871 & engineering, architectural and surveying services & 290 & 20.3 & 0.0072 & 0.0092 \\
\hline 873 & research, development and testing services & 72 & 8.0 & -0.0166 & 0.0392 \\
\hline 874 & management and public relations services & 150 & 22.3 & 0.0082 & 0.0025 \\
\hline
\end{tabular}

Notes: technology difference $=$ mean (intangible asset ratio of domestic firm - intangible asset ratio of foreign firms) in industry j over sample period 1994-2001.

$\mathrm{NA}=$ industries without foreign presence during entire sample period 1994-2001

foreign intangible asset ratio = mean (intangible asset ratio of foreign firms) in industry j over sample period 1994-2001. 